\title{
UNCHARTED PATH: UNDERSTANDING THE EXPERIENCES OF FIRST-GENERATION STUDENTS ON THEIR JOURNEY TOWARD THE EDUCATION DOCTORATE IN THE CALIFORNIA STATE UNIVERSITY SYSTEM
}

\author{
A Dissertation submitted to the faculty of \\ AS \\ 35 \\ 2016 \\ EDD \\ - $h 49$ \\ San Francisco State University \\ In partial fulfillment of \\ the requirements for \\ the Degree \\ Doctor of Education \\ In \\ Educational Leadership
}

by

Clyde Henry Lewis, Jr.

San Francisco, California

August 2016 
Copyright by

Clyde Henry Lewis, Jr.

2016 


\section{CERTIFICATION OF APPROVAL}

I certify that I have read Uncharted Path: Understanding the Experiences of FirstGeneration Students on their Journey Toward the Education Doctorate in the California State University System by Clyde H. Lewis, Jr., and that in my opinion this work meets the criteria for approving a thesis submitted in partial fulfillment of the requirement for the degree Doctorate in Education in Educational Leadership at San Francisco State University.

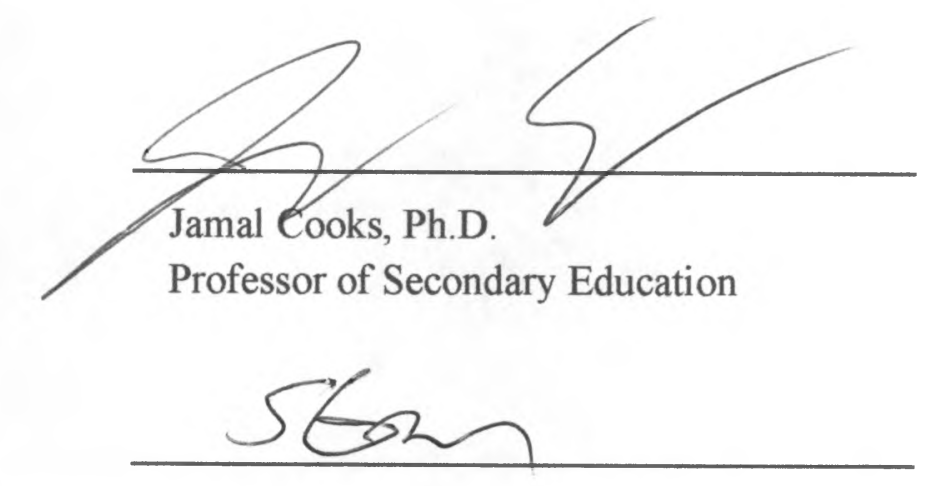

Sheldon Gen, Ph.D.

Associate Professor of Public Administration

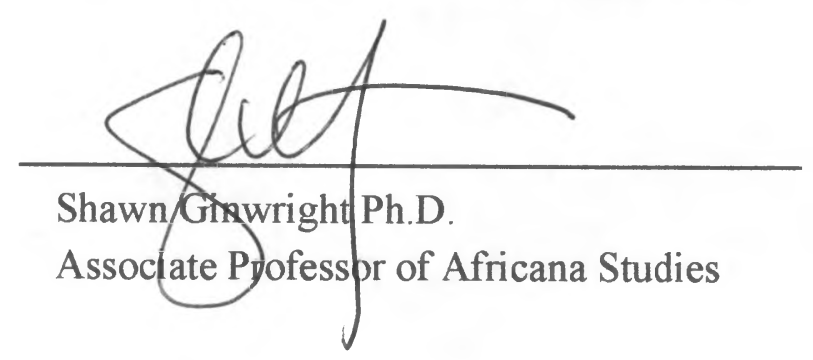




\title{
UNCHARTED PATH: UNDERSTANDING THE EXPERIENCES OF FIRST- GENERATION STUDENTS ON THEIR JOURNEY TOWARD THE EDUCATION DOCTORATE IN THE CALIFORNIA STATE UNIVERSITY SYSTEM
}

\author{
Clyde Henry Lewis, Jr. \\ San Francisco, California
}

2016

In 2005 the California legislature amended The Master Plan for Higher Education by passing Senate Bill 724 authorizing the California State University (CSU) system to offer education doctorate degrees (Ed.D.). The purpose was to prepare future leaders of pre-school through twelfth grade schools and community colleges to develop and implement measurable improvements in student achievement. The problem is that although the legislation defined how Ed.D. program graduates are to address diversity, equity and opportunity for P-12 and community college students once they graduate, there is little attention given to the variance of the demographics of the student that enrolled in the programs. The purpose of this study is to examine the characteristics, motivators and barriers for current and former first-generation students in the CSU Ed.D. programs. Specifically, this study seeks to understand the experiences of first-generation students on their educational journey toward the doctorate in the CSU. The findings from this mixed-methods study suggest that the CSU Ed.D. program is fulfilling its goal of diversifying the pool of doctoral trained administrators. Although participants for this study were also likely to be White $(48.1 \%)$ and female $(71.8 \%)$, other ethnic groups were better represented than the national average. Additionally, this study found that nearly half of all respondents were first-generation (49\%). Further, the results of this study suggest that a sense of personal fulfilment both to themselves and to their communities was a greater influence for their continuance toward the doctorate for both first-generation students and their non-first-generation peers. Participants expressed that they were not likely to know about or utilize student support services during their academic journey.

I certify that the Abstract is a correct representation of the content of this dissertation.
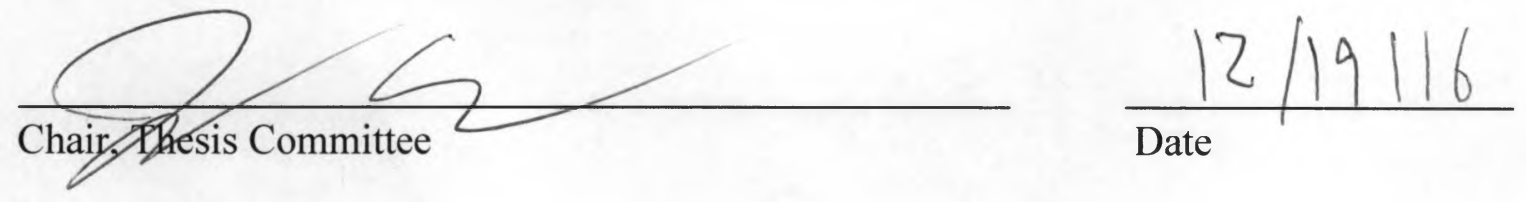


\section{PREFACE AND/OR ACKNOWLEDGEMENTS}

I would like to begin by thanking my wife, Nami Lewis and children, Sayuri June Lewis and Clyde Toshihiro Lewis III. Without their support and encouragement this process would have been much more difficult.

Next I would like to thank my family, friends and community to whom I am eternally indebted for helping to develop my resolve.

To Dr. Darnell Cole, your belief and guidance continues to inspire me and my development as an educator and researcher.

To Dr. Tomoko Yoshida, the time, energy and guidance you provided helped to solidify who I have become as a researcher, educator and person.

To Dr. Jim and Leslie Lessenger, thank you for your support, encouragement and edits.

To Dr. Shawn Ginwright, thank you for your steadfast dedication to ensuring that my analytic lens was always critical and inclusive.

To Dr. Sheldon Gen, structure is always one of the hardest things to maintain. Thank you for always ensuring that I stayed true to the agreed upon structure.

Lastly, to my Chair, Dr. Jamal Cooks, this journey has been filled with trials, tribulations and pitfalls and through every step across those burning sands, you have been there. Thank you for helping me understand to the fight when I was hardest hit, because it's when things seem worst, that I mustn't quit. 


\section{TABLE OF CONTENTS}

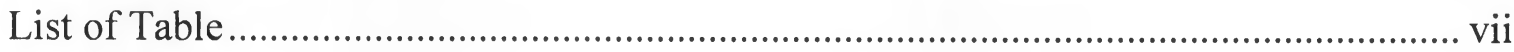

List of Figures ...................................................................................................... vii

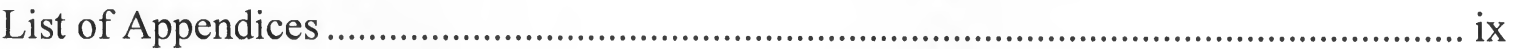

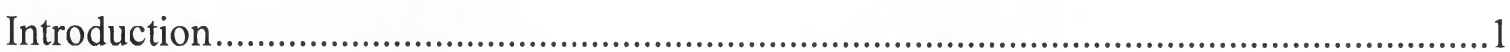

The Education Problem......................................................................................

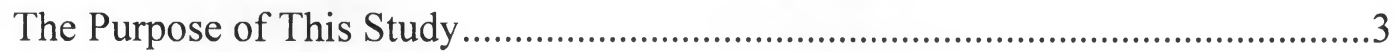

The Research Questions.......................................................................................

Implications of the Study ................................................................................6

The Conceptual Framework of this Study ……………......................................8

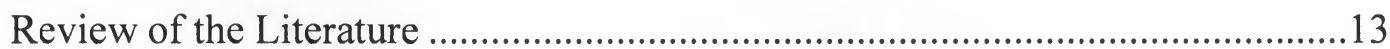

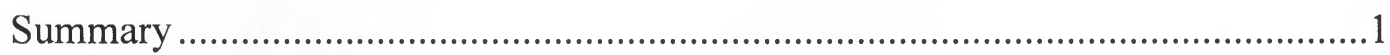

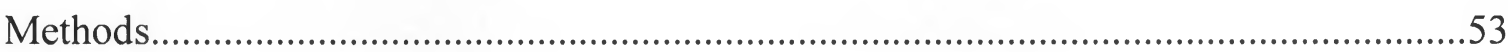

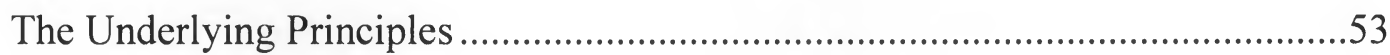

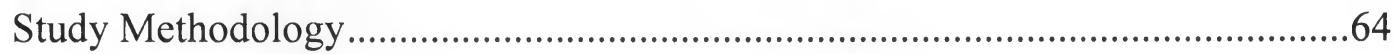

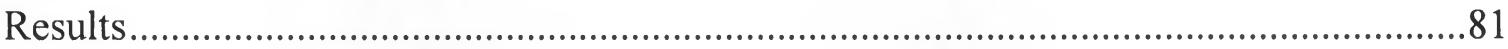

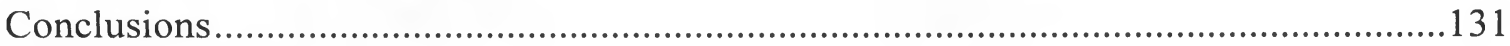

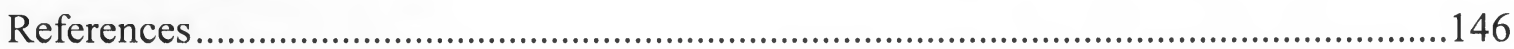

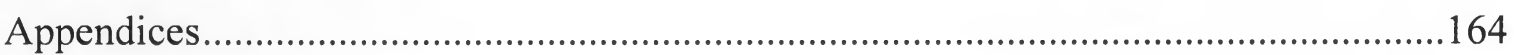




\section{LIST OF TABLES}

Table

Page

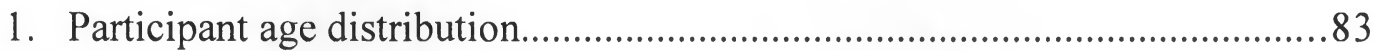

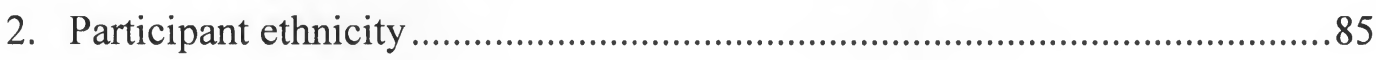

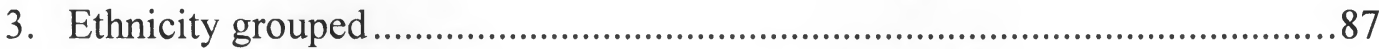

4. Gender breakdown of first-generation and non-first-generation respondents.89

5. Gender breakdown of total respondent population..........................................90

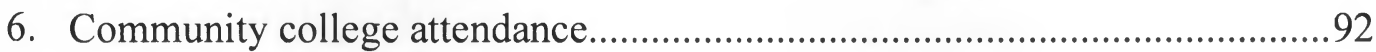

7. Participant involvement in college transition programs...................................93

8. Involvement in college transition programs in college......................................95

9. Worked 20 or more hours per week as an undergraduate...............................96

10. Received financial support from family as an undergraduate...........................98

11. Work off campus as an undergraduate.............................................................99

12. Worked at least 20 hours per week as a master's degree student......................101

13. Receipt of financial support from family as a graduate student.......................102

14. Participants working in an education related field...........................................104

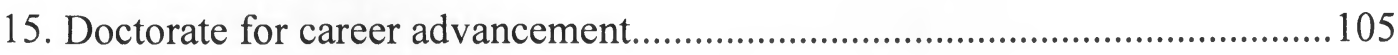

16. Lived on campus as an undergraduate............................................................107

17. Received financial aid as an undergraduate................................................108

18. Received financial aid as a graduate student..................................................109

19. Stopped out as an undergraduate ……...........................................................111 


\section{LIST OF FIGURES}

Figures

Page

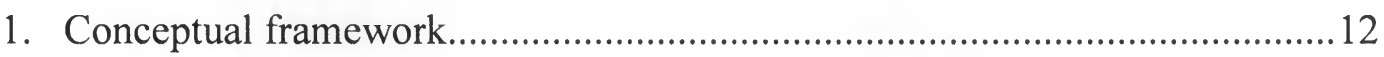

2. Embedded Mixed Methods Design....................................................................57 


\section{LIST OF APPENDICES}

Appendix

1. San Francisco State University: Informed consent to participate in

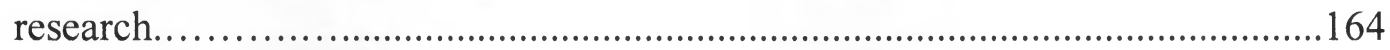

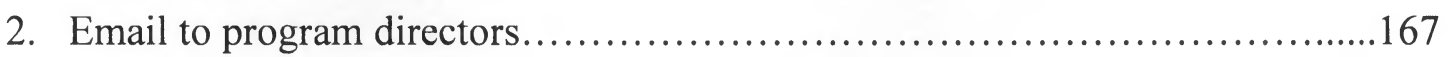

3. Understanding the experiences of students on their journey toward the education

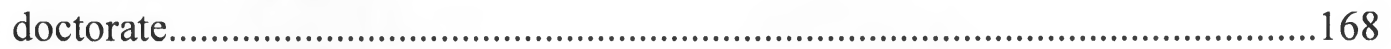

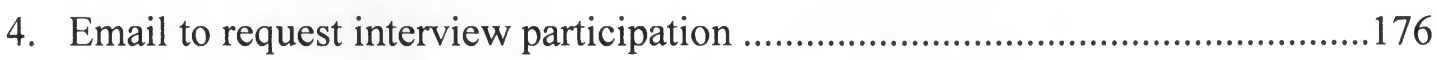




\section{Chapter 1}

\section{THE EDUCATION PROBLEM}

In 2005 the California legislature amended The Master Plan for Higher Education (Master Plan) by passing Senate Bill 724 (SB724) authorizing the California State University (CSU) system to offer education doctorate degrees (Ed.D.). The purpose was to prepare future leaders of pre-school through twelfth grade (P-12) schools and community colleges to develop and implement measurable improvements in student achievement (Office of the Chancellor, 2007). The authorization mandates a Core Educational Leadership Program Concept (CELCP) framework of leadership foundations, leadership specialization, and research methodology. These concepts include benchmarks for measuring the success of CSU Ed.D. programs (Office of the Chancellor, 2007).

The leadership goals of the legislation require that CSU Ed.D. programs focus on "addressing issues of diversity, equity and opportunity, including attention to special populations" (Office of the Chancellor, 2007, p. 11). The leadership specialization criteria require educational leaders to concentrate on "creating shared aspirations and expectations that result in supportive environments and student excellence" (Office of the Chancellor, 2007, p.12). The research methodology criteria require education leaders to use assessment and evaluation tools to collect data that will aid in the development of student interventions and influence decision making and improvements. Collectively, 
these core concepts create a model of doctoral education that is expected to engage “...program philosophy, pedagogy, and target populations” (Office of the Chancellor, 2007, p.11).

The problem is that although the legislation defined how Ed.D. program graduates are to address diversity, equity and opportunity for P-12 and community college students once they graduate, there was little attention given to the variance of the demographics of the student that enrolled in the programs. Historically in higher education, the voices of diverse populations have been largely absent from conversations about how to address their needs (Bogue \& Aper, 2000). Without representation from the differing groups that exist within California, the ability for future CSU Ed.D. students to respond to the needs of California's population will mirror previous attempts at addressing their issues by having elite leaders develop programs that address what they believe to be the needs of the rest of the population. It is for this reason that representation from the diverse student populations have been a key component for structuring the CSU Ed.D. programs.

The legislation did not mention any characteristics for future students who would be pursuing the Ed.D., so determining how the student population reflects the population of California remains unclear. Understanding this key oversight is crucial when analyzing the history of exclusion in American higher education and the desire for expansion of higher education to California's complex populace. 
Because state-wide statistics for first-generation students pursuing an education doctorate, or first-generation doctoral students, are not readily reported by the CSU Ed.D. programs, stakeholders for these programs can only guess at the composition of the candidate population that has pursued the Ed.D. and will become the future educational leaders of the state. First-generation doctoral students are defined as those students who have been enrolled in CSU Ed.D. programs and were raised in a household with parents who do not hold a college degree.

Two gaps in the data are critical. First, data for students in the CSU Ed.D. programs are aggregated with other graduate programs so it is not possible to distinguish between Ed.D. students, students in inter-institutional doctoral programs (CSU and University of California doctoral programs), and master's degree candidates. Second, traditional data classifications of race, ethnicity, gender, and socioeconomic status do not capture a critical inter-group nuance: being the first in one's family to attend college and being a first-generation doctoral student.

\section{THE PURPOSE OF THIS STUDY}

The purpose of this study is to:

1. Analyze the characteristics of current and former first-generation doctoral CSU Ed.D. students.

2. Determine which students came from families without the social capital to support them as they pursue higher education and to 
determine how issues related to first-generation status were mitigated as students navigated toward the CSU Ed.D.

This information will be useful for education leaders interested in developing interventions for first-generation students at all stages of their educational pathway.

\section{Analysis of the Characteristics}

The first purpose of this research is to analyze the characteristics of CSU Ed.D. students. To better understand this relationship, this research will examine the experiences of first-generation students who are currently enrolled in or have already completed, an Ed.D. within the CSU system.

First-generation students, (Terenzini, Springer, Yaeger, Pascarella, \& Nora, 1996) when combined with low-income students accounted for more than 47 percent of all California high school graduates that attended California public post-secondary institutions in 2006 to 2007 (California Department of Education, 2013). First-generation students are among the fastest growing, yet least studied, populations in the state, especially those candidates who successfully navigate to a doctorate degree.

First-generation students in CSU Ed.D. programs would have presumably progressed through P-12 education before pursuing their doctorate. Understanding the experiences of first-generation doctoral candidates may offer insight into their educational hurdles and allow education leaders to develop obstacle-mitigating programs. While there is research about the impact of social capital, on first-generation students 
new to postsecondary education (S. K. Gardner \& Holley, 2011; Padgett, Johnson, \& Pascarella, 2012), there is little evidence of how being first-generation impacts an individual who has successfully navigated through the bachelor's and master's degree levels and has decided to pursue a doctorate. Research is consistent that first-generation students lack the necessary social capital to engage faculty (e.g., Collier \& Morgan, 2008; S. K. Gardner \& Holley, 2011) and peers (Dennis, Phinney, \& Chuateco, 2005) in ways that will improve their academic success.

\section{Students from Families Unable to Support First-generation Students}

The second purpose of this study is to determine which doctoral students come from families that were unable to support their success in higher education and to determine how these first-generation students navigated to the doctorate degree.

\section{THE RESEARCH QUESTIONS}

This research will analyze the characteristics, motivators and barriers faced by first-generation students in CSU Ed.D. programs, as well as how generational status might be mitigated as a student advances through postsecondary education and decides to pursue a doctoral degree. To that end, this study focuses on the following research questions:

1. What are the characteristics, motivators, and barriers of first-generation students in the CSU Ed.D.? 
2. What resources were useful in mitigating obstacles for first-generation CSU Ed.D. students as they progressed toward the Ed.D. degree?

\section{IMPLICATIONS OF THE STUDY}

There are three areas where the implications for this study are relevant:

1. Leadership.

2. Diversity.

3. Equity.

\section{Leadership Implications}

The CSU Ed.D. is intended to provide affordable access to graduate school and to develop leadership for P-12 public schools and community colleges in California (Senate Bill No. 724 Chapter 269, 2005). While these goals offer justification for continuing the CSU doctorate program, it is not known why students choose the program or what the characteristics of those students are. It is not known which of these students continued a family tradition of using education to leverage academic and leadership skills learned at home and which students might be the first in their family to pursue any postsecondary education.

California legislators and CSU leaders will be able to use this research to develop programs that will more accurately address the needs of both first-generation Ed.D. students and P-12 first-generation students. 


\section{Diversity Implications}

Currently, student demographic information gathering is confined to race, ethnicity, gender, and socio-economic status. While understanding these characteristics is important, at least one additional characteristic could inform policy development and improve student retention: generational status. Although this information is not currently gathered for CSU Ed.D. programs, understanding the influence of generational status can help state and local leaders provide more interventions than are currently provided. By understanding the impact of generational status, educational leaders can implement developmental programs that are removed from the stigma of remediation. This will allow students to meet others who are experiencing similar situations and receive support from the institution and their peers. Understanding constructive ways to support firstgeneration students is especially important as they represent 47 percent of all undergraduate students across the US (Choy, 2001).

\section{Equity Implications}

Understanding the characteristics, motivators, and barriers faced by firstgeneration doctoral students is an equity issue because this group potentially faces increased challenges of acclimation and acculturation throughout their academic career (Dennis et. al., 2005; Padgett et. al., 2012). Because they are largely understudied, firstgeneration doctoral students are a largely unidentified group who may have increased the risk of attrition when compared to their peers with college-educated parents. 
As students are commonly examined categorically (race, ethnicity, age, gender, and socioeconomic status), challenges inherent to the first-generation status may wrongly be attributed to other risk factors or missed entirely. For example, a first-generation White female doctoral student may have difficulty forming networks, potentially negating the theoretical benefits of her White race and thereby increasing her risk of attrition. If a first-generation African American female doctoral student experienced feelings of marginalization and eventually dropped out, without further inquiry it is likely her withdrawal would be associated with ethnicity or gender, but not necessarily generational status. To more effectively address the concerns of a diverse student body, it is important to have an accurate understanding of student demographics and experiences. For these reasons, it is important to consider first-generation status as a categorically underrepresented classification. Otherwise, their experiences and resultant risks of attrition may be inaccurately attributed.

\section{THE CONCEPTUAL FRAMEWORK OF THIS STUDY}

This section describes the conceptual framework for understanding, analyzing, and designing of the relationships in this study. For the present study, three theories were used:

1. Resilience.

2. Identity development.

3. Social and cultural capital. 


\section{Resilience}

The construct of resilience refers to an individual's response to a situation or stimuli (Luthar, Cicchetti, \& Becker, 2000). Those who when faced with difficulty and uncertainty, can find approaches that will support their desired outcome. Many firstgeneration students that come from low-income communities (Ishiyama \& Hopkins, 2003; Thayer, 2000) and are ethnic minorities (Choy, 2001; Lohfink \& Paulsen, 2005), are faced with unique challenges in academia. The response to these challenges inform their later academic success and while not a characteristics trait, does impact the individual's identity development.

\section{Identity Development}

The examination of identity development has undergone several iterations to understand how students develop over time. Early models examined psychosocial identity (Erickson, 1959) which depicted development as a series of tasks characterized by specific, often age related developmental stages (Jones, Abes, \& Magolda, 2013). Guided by the "epigenetic principal" which suggests that "anything that grows has a ground plan...and from out of this ground plan the parts arise, to form a functioning whole" (Erickson, 1959, p. 52), identity development provided a lens from which researchers could understand how a student's identity is influenced by social and socializing experiences. 
Later models examining identity development applied these developmental stages to college matriculation (Chickering \& Gamson, 1987), gender (Gilligan, 1982), and race and ethnicity (Cross Jr., 1995). These models sought to understand how a student's identity was influenced by entering higher education and how it developed over the course of their undergraduate tenure. These models were also structured in stages and purported that as students experienced higher education they would be pushed into different stages of development. As students progressed through the different stages, they would either adapt to their surroundings or continue to face challenges.

While earlier models of identity development used two constructs (e.g., race and being a student), more recent models have begun examining multiple identity development. Multiple identity development theories provide an intersectional framework that acknowledges the existence of multiple identities and the ways in which they intersect (Jones et al., 2013).

Being the first in one's family to attend college, under earlier models, would have only provided a singular lens from which to understand first-generation student experience. Multiple identity development models allow researchers to examine an array of characteristics (e.g., first-generation status, gender, age, ethnicity, and socioeconomic status), which allows for a more accurate examination the student experience.

\section{Social and Cultural Capital}


In its materialized form, capital enables the appropriation of social energy in the form of living labor (Bourdieu, 1986). Using this understanding of capital, Bourdieu (1986) developed the notions of social and cultural capital.

Social capital refers to the relationships and networks among people who live and work in a particular society or setting, enabling effective function (Bourdieu, 1986). Applied to higher education, social capital refers to the networks and support structures that foster academic success. These networks include peer networks, faculty relationships and student success resources.

Cultural capital refers to non-financial social resources that increases social mobility beyond economic means. Cultural capital can include style of dress, education, speech patterns, and physical appearance.

Taken together, social and cultural capital refer to the normative behaviors and styles associated with success in an environment. In academia, social and cultural capital supports student success as students who are aware of institutional supports (i.e. social capital) and understand how to utilize those tools to foster their success (i.e., cultural capital) are more likely to be successful. 
Figure 1.1. Conceptual Framework.

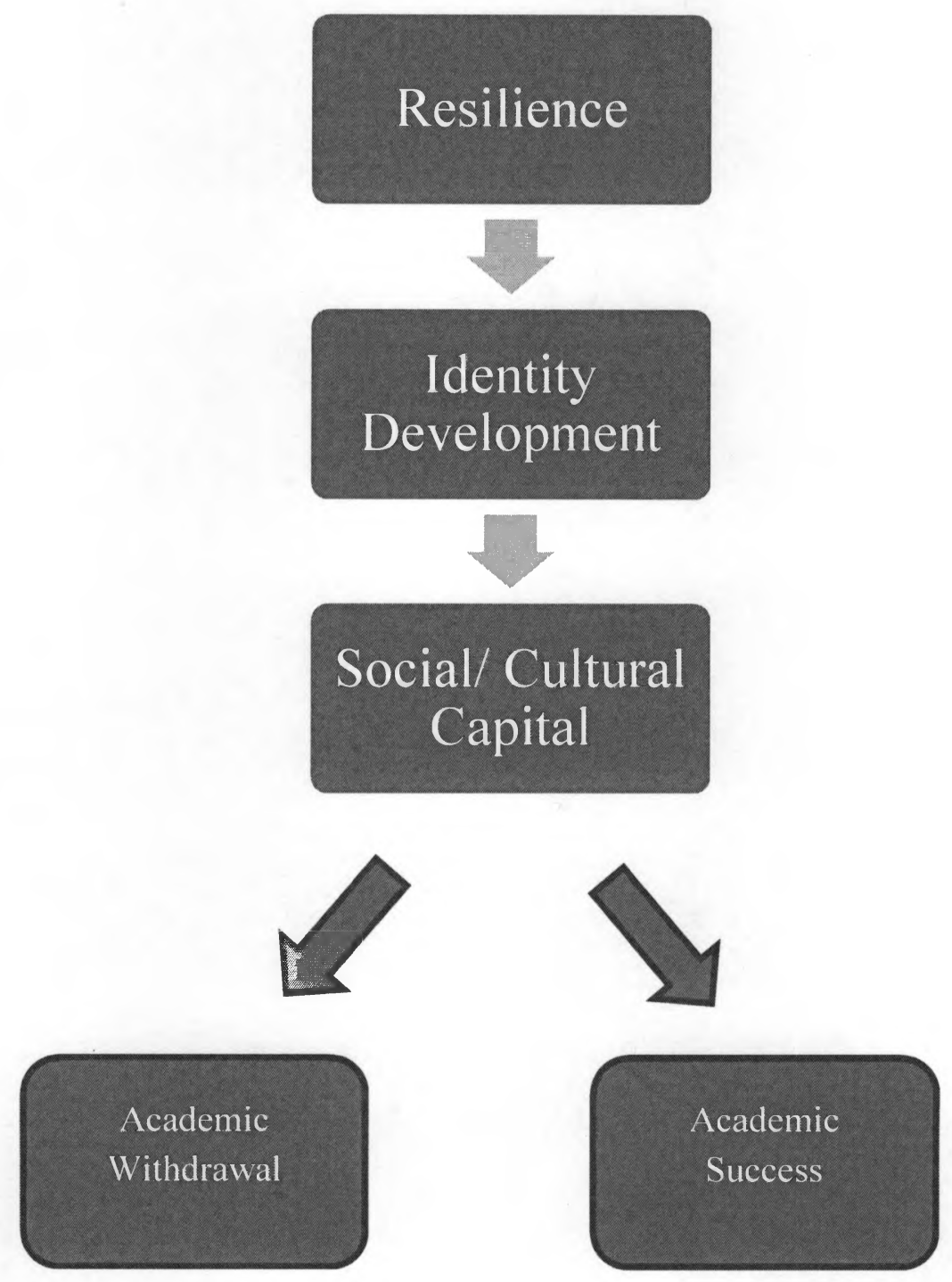




\section{CHAPTER 2}

\section{REVIEW OF THE LITERATURE}

Post-secondary student success has been a topic of research for decades

(Pascarella \& Terenzini, 1980; Terenzini \& Pascarella, 1978; Dennis, Phinney, \& Chuateco, 2005; Tinto, 1975; Tinto, 1998). Historically, this research was limited in scope as researchers focused on the undergraduate experience (Pascarella \& Terenzini, 1979; Tinto, 1975). Research on the undergraduate experience placed student populations in the distinct silos of race, gender, age, and socioeconomic status which prevented an examination of intergroup nuance. For a more holistic view of student success, researchers have widened their descriptive lenses to include the influence of generational status (Billson \& Terry, 1982; Lohfink \& Paulsen, 2005; Terenzini, Springer, Yaeger, Pascarella, \& Nora, 1996).

Even with the expansion toward an inclusive examination of undergraduate student experiences, researchers have given little attention to understanding post-graduate student progression toward a doctorate. Thus, little is known about the factors that influence the success of doctoral students toward degree completion. Even less is known about the experiences of students who are pursuing an educational doctorate (Ed.D.)(National Science Foundation \& National Center for Science and Engineering Statistics, 2015). Even when researchers examine post-graduate success, rarely do they focus on the success of first-generation doctoral students who are pursuing an Ed.D. 
This review will include relevant literature on the characteristics, motivators, and barriers of both undergraduate and graduate first-generation students. The theoretical framework was developed based on the findings from previous studies. This framework combined with the lack of available data on first-generation students in the CSU Ed.D. programs necessitated the use of the embedded mixed-methods model used for this study. This literature review will feature:

1. A history of the development of U.S. higher education environment.

2. The California higher education system and student access and how there have been students who were denied access.

3. The history of the California State University (CSU) education doctorate program.

4. An examination of research on first-generation student characteristics.

5. An analysis of existing literature on the motivations for first-generation students to pursue graduate degrees.

6. An analysis of the existing literature on the academic barriers to pursue graduate degrees.

7. An investigation of the tools that first-generation graduate students use to navigate toward their doctoral goals. 


\section{The U.S. Higher Education Environment}

The U.S. higher education environment will be reviewed in four ways:

1. The institutional context.

2. Student development.

3. The progression of student development.

4. The establishment of land grant and normal schools.

The institutional context. Chartered in 1636 , Harvard University originally focused on educating and preparing White males for the clergy (Bogue \& Aper, 2000). While serving the needs of this homogeneous population, Harvard administrators fell short of realizing how the lack of intellectual differentiation would influence America's educational evolution. Harvard and institutions like it were charted before public education was formally developed in the U.S. (Altbach, Berdahl, \& Gumport, 1999). Schools that came later copied the structure and focus of their pre-Revolutionary Ivy League predecessors. Even with calls for diversity, exclusive Ivy League institutions remained largely homogenous, yet their alumnae were called upon to design educational policy for an increasingly diverse citizenry (Bogue \& Aper, 2000). The early exclusion of diverse voices in establishing the U.S. higher educational framework informs how the gaps in educational access for diverse groups continue to widen.

Traditionally, family resources and religious affiliation served as the primary gatekeeper for higher education. However, with the social expansion created by the 
industrial revolution, U.S. higher education responded in 1901 by developing the community college system (McClellan, Stringer, Barr, \& National Association of Student Personnel Administrators, 2009). Community or junior colleges were initially designed to serve as incubators for advancement to higher education. This mission changed during the Depression when, in response to widespread unemployment coupled with an untrained citizenry, community colleges began offering job training to curb widespread unemployment. This institutional shift was advanced again in 1944 with the introduction of the GI Bill (Bogue \& Aper, 2000).

The Serviceman's Readjustment Act of 1944 (GI Bill) afforded veterans access to low-cost mortgages, low-interest loans, tuition and living expenses to attend college, and one year of unemployment compensation (Altbach et al., 1999; Bogue \& Aper, 2000). The GI Bill served as an early model for the Federal financial aid system which provided financial support for college-bound civilians. These social services provided access to higher education and allowed student entrance to more colleges and universities than at any other point in history. However, even with this increased access to higher education, there were still large segments of the population who were denied entry (Engle \& Tinto, 2008; Gandara, 1995; Graaf, 1986; Kim, 2004).

Influenced by the Civil Rights movement, President Lyndon Johnson signed the Higher Education Act of 1965 to improve student access to higher education. In providing Federal support for public and private scholarships, the Act sought to provide broader access to higher education and included underserved populations (Bogue \& Aper, 
2000). The Civil Rights movement was the first collective social movement in American history that provided an even playing field for large segments of the American populace to receive higher education (Bogue \& Aper, 2000).

It should be noted that while funding for public higher education is supplemented by the federal government, states are largely responsible for funding their public institutions, and for determining how funds are used to support students.

Student development. In the decades before the Civil Rights movement, higher education leaders began to develop a structure focused on addressing student need. The Student Personnel Point-of-View Report (SPPV) (American Council on Education, 1937), resulted from a two-day conference of The American Council On Education in 1937. The SPPV report suggested that institutions should:

- Understand all students holistically.

- Understand that all students have dignity.

- Work to develop the full potentiality of the student.

- Recognize that learning is the result of a variety of rich experiences that take place both inside and outside of the classroom.

In 1949, the SPPV was amended to include:

- Fuller realization of all the tenets of democracy.

- Provision of opportunities for international understanding and coordination. 
- The inclusion of creativity and imagination.

- The provision of training related to the student's personnel career goals (American Council on Education, Committee on Student Personnel Work, \& Williamson, 1949).

The SPPV report states that higher education's central purpose is the "...preservation, transmittal, and enrichment of culture by means of instruction, scholarly work, and scientific research" (American Council on Education, 1949, p. 21). Over time, the interpretation of this purpose has shifted from socio-religious to institutional needs, and then to student development and, most recently, student identity development. Since the Civil Rights Movement of the 1960s, American higher education has concentrated considerable efforts on understanding how students' identity is shaped through the lenses of race, ethnicity (Bonilla-Silva, 2001; Espinoza-Herold, 2003; Wilson, 2010), gender (Almquist, Angrist, \& American Sociological Association, 1970; Hughes \& HowardHamilton, 2003; Lugg, 2003), socioeconomic status (Sellers, Satcher, \& Comas, 1999), and age (Chow \& Healey, 2008). While these efforts have contributed to improvements of the academic landscape, they fall short of fully explaining differences that exist within student populations and, as a result, fail to fully address student need.

The social focus on student identity development served as the impetus for educational institutions to draft initiatives that would enlarge the academic pipeline to a more diverse array of students (Bowen \& Bok, 1998). For many years, race, ethnicity, age, and gender were the analytic lenses that researchers used to understand how students 
evolve over the course of their academic life. While the construct used in previous research has provided a much needed frame for an initial understanding of student identity, for a full appreciation of the complexity that exists between students an additional metric was needed (Jones, 1997). For example, a White female middle-class student could be the first in her family to attend college. Under current demographic information gathering, the focus would be placed on her ethnicity and social class which may serve as a barrier to her being considered for needed resources. Without understanding the influences of generational status, the purported benefits generally associated with race and socioeconomic status may unintentionally mask the needs of this student (Espinoza-Herold, 2003; Thayer, 2000; Wilson, 2010).

The progression of student development. The push toward the diversification of higher education has long received harsh criticisms. This thinking is exampled by the argument that higher education should not serve as a "... service station for the general public" (Altbach, et al., 1999, p. 58). This argument was further highlighted by the then President of Dartmouth College, Earnest Hopkins, who stated that “...too many young men are going to college" (Altbach et al., 1999, p. 58). While these feelings were not universal, they serve as an example of how elitist thinking justified the continued stratification of higher education and exemplify historic feelings about student population diversity in higher education.

In 1932 the Carnegie Foundation's report, The State of Education in California, was the first documentation of systematic stratification of institutions of higher education 
(Altbach et al., 1999). The report suggested that the University of California system should focus on serving the needs of the students deemed 'fit' for its intuitional rigor. This study used three criteria to determine this elite status:

1. Collegiate ideal: To be determined by student "peer societies."

2. The quality of undergraduate learning: Highlighted by "raised standards."

3. Advancing knowledge: Which would serve as "...the touchstone of research and graduate education" (Altbach, et al., 1999, p. 59).

These criteria demonstrate how social stratification was maintained, as it is unlikely that minority, women, or low-income students had the requisite capital to meet these conditions.

While these leaders were interested in supporting the rigors that would improve higher education, their sentiments served as a barrier for those students trying to use education as a tool for upward social mobility (Breen \& Jonsson, 2005). These statements highlight that while the focus on student development has created opportunity and has improved the educational climate, the underlying push to maintain rigor may unintentionally recreate social stratification (Ogbu, 1994).

The establishment of land grant colleges and normal schools. The rapid expansion of manufacturing, agriculture and transportation caused by the industrial revolution required employees to have new training in fields like science, agriculture, and engineering. Colleges responded by expanding their professional curriculum (Thelin, 
2004). This educational expansion was triggered by the historic Land Grant, or Morrill, Acts of 1862 and 1890. The Acts provided funding and land to the states to spur the growth of institutions of higher education. This expansion encouraged state colleges to develop a curriculum aimed at occupational utility (Geiger 1986). Introduced by Congressman Justin Smith Morrill, the Acts provided 30,000 acres of Federal land to each congressional representative based on the census in 1860. The land or profits from its sale were to be used to develop educational institutions. Land Grant colleges were the largest investments in extending education to a broader slice of the American populace in history. The Acts were effective in expanding opportunities to women, various minority groups, and the poor, while also serving the burgeoning White middle class (Bogue \& Aper, 2000). While attention was being paid to expanding access, research during this era was inadequately refined to document how barriers negatively impacted the social mobility of student subpopulations (Breen \& Jonsson, 2005).

Normal schools derive their names from the Latin norma which translates to conforming to a rule, pattern or model (Bogue \& Aper, 2000). Both public and private institutions developed normal schools or teacher colleges to add teaching certificates to their offerings. While some of the institutions were coeducational, others were designed specifically for women or specific minority groups. These colleges would become the first institutions of higher education to have a student body that reflected the diversity of their surrounding populace (Thelin, 2004). As these institutions expanded, women and minorities benefitted by furthering their education, but society in general saw a greater 
benefit from the expansion of trained teachers and educational opportunities. Since their inception, normal schools have provided societal benefits that can still be felt today as P12 teachers across the nation are required to have degrees, certification or licensure (Bogue \& Aper, 2000).

\section{The California higher education system}

Authored by California Assemblywoman Dorothy Donahue, the California Higher Education Act of 1960 authorized the development, expansion and integration of curriculum and standards at all California public institutions of higher education for a ten-year period. The Act also structured the system to respond to increases in student attendance due to population increases (Geiser \& Atkinson, 2013).

UC Chancellor Clark Kerr is considered to have fathered the California Plan for Higher Education by leading a group of educators and state leaders in developing a structure to accommodate the increased educational demands of the post-war influx of baby boomers (Geiser \& Atkinson, 2013). This team expanded the work of Assemblywoman Donahoe and developed the operational guidelines (Geiser \& Atkinson, 2013).

After considerable debate, the legislature approved the Plan in 1960 and the law became known as the Donahue Education Act of 1960. This plan, which University of California Professor of Sociology Neil Smelser referred to as "... one of the most important innovations of the $20^{\text {th }}$ century" ("12.03.2003 - Clark Kerr's legacy: 1960 
Master Plan transformed higher education," n.d.), addressed issues of access, college affordability and student opportunity. Historians and academics alike hailed the Plan as a benefit to the public education system in California and it has had a strong influence on other domestic and international college systems (Altbach et al., 1999).

Included in the Plan were five major reforms. The first reform determined institutional responsibility for the California's public education system. It designated the University of California (UC) as the primary research and graduate institution in the state. This distinction gave UC the exclusive responsibility of offering doctoral degrees in law, medicine, dentistry, veterinary science, and other professions. The CSU system was positioned as an undergraduate and graduate system and was to focus on professional and teacher education. The community colleges were designated as academic and vocational institutions and were to provide lower division undergraduate instruction, workforce development and training, community service courses, remediation and non-credit courses (Geiser \& Atkinson, 2013).

The resultant educational segmentation caused an imbalance in four-year and twoyear institutional enrollment, disproportionately impacting African American and Latino student populations (Geiser \& Atkinson, 2013). The California Postsecondary Education Commission (CPEC) (2008), reported that fewer than 13.5 percent of African American and Latino high school graduates combined were eligible for enrollment at UC after the implementation of the Act. This is especially important when considering that these two ethnic groups represent most of the P-12 enrollment in California (Geiser \& Atkinson, 
2010). Although California ranks $13^{\text {th }}$ in minority representation in public higher education, only about 5 percent of those students are enrolled in the state's four year institutions (Geiser \& Atkinson, 2010). Like previous decisions determining the direction of state education, the Donahoe Act was promulgated without considering the long-term impact on underserved and underrepresented groups.

The second reform of the Donahoe Act differentiated admission requirements by allowing the UC to select students from among the top one-eighth of high school graduates, the CSU from the top one-third of the class, and the community colleges to admit all students interested in higher education or vocational training.

The remaining three reforms in the Donahoe Act included:

1. A commitment to tuition-free education for California residents, which was later altered to reduced tuition because of increases in college costs and availability of student aid.

2. A governance structure that includes the UC Board of Regents, The CSU Board of Trustees and the Community College Board of Governors.

3. The development of a commission to coordinate higher education policy, which is now referred to as the California Postsecondary Education Commission ("Information Digest 1979. Postsecondary Education in California.," 1979). 
According to Geiser \& Atkinson (2013) these reforms were designed to accommodate the rapidly expanding California population. However, the demand also created a greater need for doctoral-trained educational leaders to lead the P-12 schools (Geiser \& Atkinson, 2013).

\section{The Evolution of the CSU Educational Doctorate Program}

While California recorded a 21 percent increase in demand for educational administrators in the decade between 1998 and 2008, the number of doctorates granted by the UC and private institutions fell short of fulfilling this demand during this same period (Commission, 2006).

The demand for educational leaders was further complicated by large numbers of California administrators arriving at retirement age. In 2008, it was reported that nearly 80 percent of the state's superintendents would be retirement eligible within five years (Geiser \& Atkinson, 2013). Despite California's continued shortfall, the UC and private higher education leadership staunchly rejected the idea of CSU doctoral degrees. In an open letter to Assemblywoman Carol Liu on June 22, 2005 representatives from UC opposed the CSU doctorate by stating that amending the Donahoe Act would "open the door to program duplication" (SB724 (Scott), As Amended on April 5, 2005 Scheduled for Hearing in the Assembly Higher Education Committee on July 5, 2005 Position (Oppose), 2005). Because no independent needs assessment was conducted to determine the demand for a CSU doctoral degree, opponents argued that altering the Plan was 
unfeasible. Opponents argued that the addition of a CSU education doctorate would increase costs to the entire CSU system and siphon off resources from existing programs. Additional arguments against altering the Act suggested that UC/CSU joint programs would be sufficient to address California's leadership needs if given the chance to properly develop (“California Master Plan for Higher Education," n.d.). Although opponents made this claim, a later study suggested California public education would have needed to graduate more than 600 doctoral degrees per year to address its yearly shortfall of educational administrators that hold doctorates (Geiser \& Atkinson, 2013).

Since CSU began offering doctorates, 715 students have completed the program with the largest cohort graduating in 2013 (Cal State Analytics Page, 2014). In the first three entering classes, 13 percent of students withdrew from the program after 2 years (Matosantos \& Reed, 2011) as compared to 28 percent for the University of California doctoral programs (Office of the President, 2014). These statistics are further highlighted by the fact that of those graduates, 47 percent self-identified as belonging to an ethnic or minority group (Commission, 2006).

\section{Research on First-Generation Student Characteristics}

First-generation students are defined as those students who were raised in households where neither parent received a bachelor's degree (Terenzini et al., 1996). According to Choy, 34 percent of all students entering higher education in the 1995 academic year were first-generation (Choy, 2001). While the number of first-generation 
students entering undergraduate institutions was relatively high in recent years, the number of first-generation students pursuing a Ph.D. has seen a steady decline since it peaked at about 19,000 students in 1973 (National Science Foundation \& National Center for Science and Engineering Statistics, 2015). The NSF report also noted that when firstgeneration students entered doctoral programs, they were most likely to pursue a doctorate in the field of education. One consideration for the decline in the number of students pursuing doctorates could be how the NSF defines doctorates. The report states that only research doctorates were included (National Science Foundation \& National Center for Science and Engineering Statistics, 2015). The exclusion of professional doctorates and the resultant decline in research doctorates could be explained by the expansion of Ed.D. programs during this timeframe.

While first-generation undergraduate students are well researched (Choy, 2001; Padgett et al., 2012; Pascarella, Pierson, \& Wolniak, 2004), examinations of their peers who decide to pursue an educational doctorate is limited.

One potential reason for the lack of research on first-generation doctoral students is the assumed small number (Engle and Tinto, 2008). Hoffer and Associates (2002) found that 37 percent of doctoral recipients stated that neither parent had earned a college degree. A recent report by the NSF and National Center for Science and Engineering Statistics found that among Ph.D. candidates there has been a large representation of first-generation students pursuing doctorates for decades (National Science Foundation \& National Center for Science and Engineering Statistics, 2015). 
An alternate explanation for the lack of research on this population suggests a mistaken belief that once students have found a way to complete their bachelor's degree, the academic barriers associated with being the first in their family to attend college should have dissipated. This position assumes that any future educational pursuits by first-generation students would mirror those of their continuing education peers, and would only include the barriers faced by all graduate students. As Gardner and Holly (2011) found in their examination of first-generation doctoral students, many of the barriers faced by first-generation doctoral students mirror those of their undergraduate peers (S. K. Gardner \& Holley, 2011). They found that first-generation doctoral students like their undergraduate counterparts lacked the requisite knowledge of the process of applying for graduate school. As the process of entering graduate school is field specific, this lack of knowledge can play a detrimental role in the success of first-generation students who decide to pursue an advanced degree (Ishiyama \& Hopkins, 2003). While these findings may also be true for non-first-generation students, they are compounded for first-generation students.

Seay and Associates (2008) found that first-generation students who pursue graduate school face obstacles related to their lack of understanding about implicit cultural behaviors associated with academic success. As the cultural behaviors associated with success in graduate school tend to be field specific, first-generation students entering graduate school in a field different from their undergraduate studies may face obstacles unrelated to the curriculum. These obstacles and feelings of alienation may serve as an 
impetus for departure. This lack of understanding can also be understood by what Coleman (1988) refers to as "norms." Coleman suggests that without a clear understanding of the norms and expectations of a given social environment, success in that environment can prove difficult. The lack of normative understanding could serve as an obstacle for all students entering graduate school, but when coupled with difficulties traditionally associated with being first-generation, they can serve as an additional obstacle to success (Collier \& Morgan, 2008; S. K. Gardner \& Holley, 2011).

To provide a detailed examination of the motivations and barriers for firstgeneration doctoral students, it is appropriate to analyze research at both the undergraduate and graduate levels. Studies have shown that the experiences of firstgeneration graduate students and their undergraduate peers are similar (S. K. Gardner \& Holley, 2011a; Woosley \& Shepler, 2011). Research on undergraduate education is relevant to the present study as it provides context for an investigation of student transition to graduate school.

Many of these studies focusing on first-generation students use qualitative methods to capture student voices in order to highlight their experiences (S. K. Gardner \& Holley, 2011; Holley \& Gardner, 2012; Ishiyama \& Hopkins, 2003; Seay et al., 2008). Other studies used quantitative methods to capture a broader picture of the demographic, educational experiences and personality characteristics of first-generation graduate students (Seay et al. 2008). 
To place first-generation students in context, each of the four demographic categorizations will be discussed:

Race. Existing research examining first-generation status and race focuses on identity development (Alessandria \& Nelson, 2005; Orbe, 2004) and social integration (Holley \& Gardner, 2012). Research on first-generation doctoral students suggests that they are more likely to belong to an ethnic minority group than their non-first-generation doctoral student peers (Lunceford, 2011; Seay et al., 2008).

Age. Research is consistent that first-generation students are more likely to be older than their non-first-generation peers when entering higher education (Terenzini et al., 1996). It is unclear if this initial gap in age impacts the age at which both groups of students decide to enter graduate school.

There are many factors that have been used to explain the reasons why firstgeneration students enter higher education later than their non-first-generation peers. Many first-generation students come from low-income families and may need to work after graduating high school which may delay their entrance into college (Terenzini et al., 1996).

Gender. Researchers examining first-generation students and their continuing education peers found that first-generation students are more likely to be minority, female, and to come from low-income communities this is true for both undergraduate (Engle \& Tinto, 2008; Hsiao, 1992; Warburton, Bugarin, \& Nunez, 2001) and graduate 
first-generation students (Seay et al., 2008). Although this finding is consistent, there has been little examination of why female first-generation students are more likely to pursue higher education than their male first-generation peers.

Socioeconomic status. One common characteristic of first-generation students is that they are more likely to come from low-socioeconomic households than their nonfirst-generation peers (Billson \& Terry, 1982; Engle \& Tinto, 2008; Terenzini et al., 1996). The lack of financial resources has lasting influences of the educational attainment of first-generation students, prior to and during their graduate studies. First-generation students are likely to feel financial pressure which increases the likelihood that they will work part or full time (Terenzini et al., 1996). Billson \& Terry (1982) found that firstgeneration students are more likely than their peers to work more off-campus hours per week than their non-first-generation peers. The effects of working off campus negatively impacts the quality of first-generation students' education in several ways. According to Stebleton \& Soria (2012), first-generation students are more likely to face academic obstacles that are compounded due to work, familial responsibilities, inadequate study skills, and weak math and English preparation. These findings support the previous research of Billson \& Terry (1982) who found that working full or part-time decreased the likelihood that first-generation students would attend academic support programs designed to enhance their academic development. These self-defeating behaviors place first-generation students at greater risk of academic hardship. 


\section{The Literature on the Motivations for First-Generation Students to Pursue}

Graduate Degrees. First-generation students comprise 41 percent of all graduate students nationally, of which nearly 15 percent are from minority groups (National Science Foundation \& National Center for Science and Engineering Statistics, 2015). This section will examine two models that have been used to explain the motivation for first-generation students to pursue higher education:

1. The self-efficacy model.

2. The college choice model.

The Self-Efficacy model. The social-cognitive concept of self-efficacy was first proposed by Bandura (1977). While social-cognitive theory has its roots in social psychology and behaviorism and only examines the individual as they are situated within a social context, self-efficacy uses a multi-dimensional model to examine the relationship between human cognition, environmental factors and human behavior (Bandura, 1977). Instead of a person's identity being constructed by either nature or nurture, Badura (1977) proposed a tripartite approach to understanding the relationship between the influences of individual cognition and its effect on biology, behavior, and the environment. In this instance, individual behavior is not determined solely by social or environmental factors, but as mediated through the person's knowledge, understanding, emotions, perceptions, and interpretations (Bandura, 1977). Specifically, self-efficacy was used to describe the relationship between social experience, individual thinking, and behavior. Bandura 
(1977) proposed that self-efficacy is a key cognitive mechanism that supports much of human behavior.

Self-efficacy can be understood by the notion that "what people think, believe, and feel affects how they behave" (Bandura, 1986, p. 25). While potentially true for all students, this understanding supports research on first-generation students which states that belief in their ability to be successful in higher education prompts their pursuit, and having their undergraduate dream actualized pushes them to decide to pursue an advanced degree (Dennis et al., 2005; Petty, 2014).

The College Choice Model. The college choice model takes the position that multiple factors influence student's college decisions. Student background, personal characteristics and familial characteristics are posited as the key characteristics for student college choice (Ranero, 1999). The college choice model has three stages (Hossler \& Gallagher, 1987; Litten, 1982; Paulsen, 1990):

1. College aspiration.

2. College search.

3. College choice.

The college aspiration stage. The first stage of the college choice model is where students make the determination about whether they will attend college (Paulsen, 1990). This is a key stage for first-generation students as several factors, including parental education level and socioeconomic status, influence the initial decision (Hossler \& 
Gallagher, 1987; Litten, 1982; Paulsen, 1990). The initial decision is of special import for this population as first-generation students are more likely to come from low-income families (Choy, 2001; Nunez \& Cuccaro-Alamin, 1998; Schmidt, 2003; Terenzini et al., 1996).

During the aspiration stage, pre-college experiences impact student decisions. Paulsen found that those students who participate in extracurricular activities such as athletics, student government, or other club activities during high school are more likely to attend college than their peers who did not. Paulsen suggests a correlation between extracurricular activities and college matriculation that can be attributed to students who seek high personal achievement, of which they see college as yet another goal (Paulsen, 1990).

The college search stage. This stage is when students begin to learn whether they meet the conditions and expectations of their aspirations. Students in this stage make themselves knowledgeable through seeking information about the requirements of the colleges they are interested in attending (Hossler \& Gallagher, 1987; Litten, 1982; Paulsen, 1990).

First-generation students are at a distinct disadvantage at this stage as it requires both an understanding of the processes of college enrollment (e.g., financial aid, application fees, etc.) and planning support from either family or high school counselors (A Shared Agenda, 2004; Thayer, 2000; Vargas, 2004). The lack of a strategic plan 
coupled with the fact that first-generations students often enroll in college without having planned or chosen a major serves as a barrier. The college search phase is also complicated for first-generation students as they are less likely to know about or to seek educational services designed to support them (Thayer, 2000).

The college choice stage. The third stage is characterized by the student's acceptance into the institutions where they applied. Students are then charged with determining which institution makes the best fit for them based on personal and institutional characteristics. In this stage, students consider which factors would best support their success (McDonough \& Antonio, 1996).

First-generation students are at a distinct disadvantage at this stage as well as they often do not understand higher education financing and other factors relevant for their success. Without participation in extracurricular activities, many first-generation students are unprepared to fully appreciate the complexities of their college choice (Hsiao, 1992; Schmidt, 2003; Thayer, 2000; Vargas, 2004).

\section{The Academic Barriers to Pursuing Graduate Degrees}

There are several barriers that contribute to the difficulties faced by firstgeneration students as they pursue higher education. While some of these barriers may be true for all students, resultant barriers are increased when coupled with being the first in one's family to attend higher education. This section will examine how the following influences can impact their educational journey: 
1. Parental educational level.

2. Socioeconomic status.

3. Social capital.

4. Finance.

5. Cultural capital.

6. Identity development.

Parental Educational Level. Initially, researchers asserted that parental education played a secondary role to student academic ability when comparing firstgeneration students and their peers who had college-educated parents (Karabel \& Astin, 1975). However, recent research suggests alternate explanations for the difficulties faced by first-generation students in higher education.

Choy (2001) found that students with college-educated parents were 30 percent more likely to enter higher education directly after high school when compared with students whose parents did not have a college degree. Students with college-educated parents were 56 percent more likely to enroll in higher education than their peers whose parents stopped their education before high school (Choy, 2001).

Recent research on parental involvement (Rowan-Kenyon, Bell, \& Perna, 2008) suggests alternate explanations for the relationship between parental education and student outcomes. If parental education plays a role in undergraduate matriculation, a 
reasonable question would be what is the influence of parental education on student matriculation to graduate school?

Rowan-Kenyon and Associates (2008) found several barriers that limit the levels in which parents are involved in their children's education. The authors found that parental education influenced their children's education in three ways:

1. Parents shape college opportunity or their children with involvement that varies based on familial socioeconomic status.

2. Parental involvement is influenced by and influences the school context for college opportunity.

3. Parental involvement is shaped by the higher education context and the social, economic, and political context of their peer groups.

The authors found that socioeconomic status was a key determinant in understanding which parents were involved in the education of their children (Rowan-Kenyon et al., 2008).

The work of Rowan-Kenyon and Associates (2008) supports the research conducted by McCarron \& Inkles (2006) who found that regardless of socioeconomic status, degree attainment for first-generation students was still limited. The authors suggested that this disparity exists even for high socioeconomic first-generation students, which was attributed to the belief that if their parents could succeed without a college degree, they would be able to as well. The authors also note that parental expectation 
about their child's education played an influential role in the aspirations of firstgeneration students.

Together, these findings suggest that parental familiarity and thoughts about education have a direct impact on their child's education. Even with the creation of programs designed to support student success while they are in school, the networks surrounding the child plays an equally important role in their academic success.

Socioeconomic Status. For low-income, first-generation students the capital gained in their home community can serve as a barrier to academic success (Bourdieu \& Passeron, 1990; Piorkowski, 1983; Schmidt, 2003). Social class is maintained by a set of agents that are subjected to similar conditions and conditioning factors because they occupy similar positions in a similar social space (Bourdieu, 1987). These factors then serve to determine community membership and social rank. People living in similar communities develop comparable beliefs about life, career and education. These beliefs inform their behaviors, mannerisms and communication. The resultant recognition and adaptation of behaviors associated with belonging to a social group are defined as capital that can situationally assist or block access to success. Beliefs about how a person should behave in a situation are socially constructed and can prove beneficial while within the community but can also serve as obstacles when a person leaves the community (Bourdieu, 1987; Bourdieu \& Passeron, 1990). 
Low-income, first-generation students may experience this social dichotomy when pursuing higher education. Although people raised in low income communities are faced with challenges associated with pursuing higher education, these challenges are exacerbated for first-generation students as being low income does not necessarily mean lack of higher education. First-generation students seeking higher education for social mobility may receive harsh criticisms from family members, neighbors, and friends for trying to leave their community. This antagonism may cause first-generation students to have negative views about higher education.

According to Bourdieu (1987) defining a social class requires the consideration of both objective (structural) and subjective (constructive) thinking. In this sense, objectivity refers to the social reality that maintains group characteristics. Social class described as being inescapable is an example of objective thinking. Objective thinking suggests that people born into the lower socioeconomic classes will remain there and are powerless to ascend. Objectivity fails to account for nuance and creates distinct and permanent hierarchal social classes (Bourdieu, 1987).

Subjectivity considers multiple factors when describing social class. This construct differs from objectivity as it considers all available conditions. Complete subjectivity makes progress difficult because as new knowledge is found, so too are additional explanations. Absolute subjectivity requires knowledge about and consideration of all existing factors that may influence a social reality. Subjectivity makes identifying and addressing obstacles difficult (Bourdieu, 1987). 
Combining objective and subjective constructs is impossible as many of the indicators used to define either are often arbitrarily assigned and based on an agenda. If a researcher's interest requires funds be directed toward financing a program, an objective or subjective trait will become the "modus operandi" for substantiating that request. These same traits are then transferred and used by the group in question as criteria for belonging to their social group. This membership can lead to the group internalization of that characterization, which then becomes a criterion to recognize and acknowledge their peers (Bourdieu, 1987).

When objectivity or subjectivity is used alone to define a group and that group internalizes the characterization of belonging to a lower class, it can result in what the French refer to as Les gens humbles, or humble people learning to behave and to stay $\underline{\text { in }}$ their place. This thinking has been shown to dissuade people from pursuing social mobility because they have learned that they would face insurmountable adversity if they tried to ascend the social ladder. This social construction is maintained by the familiarity of capital or knowledge about how to behave in each situation. Low-income communities tend to be defined objectively in terms of finance.

Historically, survivor guilt has been associated with surviving a war or natural disaster (Piorkowski, 1983). However, more recently the definition has been extended to include the guilty feelings that students develop when they were able to successfully navigate the educational environment when others around them who they feel were equal, if not more qualified, did not (Piorkowski, 1983; Tate, Williams III, \& Harden, 2013). 
Survival in this sense refers to students finding a way to traverse existing obstacles and gaining an opportunity for social mobility. Survivor guilt has been shown to negatively impact student overall well-being, the ability to develop positive relationships, and academic success (Piorkowski, 1983). Survivor guilt increases the likelihood that students will focus on the past and question why their family and peers were unable to find a way to make it to college. In the same way that the effects of being first-generation are underestimated, the effects of survivor's guilt may not be easily recognized by administrators looking to support student success. By appreciating that the student experience is multi-faceted, school administrators can develop programs to provide a holistic understanding, thereby mitigating the potentially negative effects of survivor guilt (Piorkowski, 1983).

Higher education has become an integral step for long-term vocational and economic opportunities. Educational attainment is linked to higher employment and increased earning over a lifetime (Attewell, Lavin, Domina, \& Levey, 2007). Although the rate at which students are entering higher education is increasing, there are distinct differences in the characteristics of students who complete their educational goals (Astin, 1998; Engle \& Tinto, 2008; Sanoff \& Powell, 2003). In particular, first-generation, lowincome students are less likely than their peers from higher-income families to earn a degree (Choy, 2001; Nunez \& Cuccaro-Alamin, 1998; Pascarella et al., 2004; Thayer, 2000). 
Social Capital. Social capital refers to the benefit gained by belonging to social networks, the bonding of people with similar interests, and the bridges between diverse peoples (Dekker \& Uslaner, 2003). These networks develop into systems of reciprocity and allow access to resources and opportunities to members. This capital is both implicit and explicit and serves as a barrier for those who are unfamiliar with the learned behaviors of a setting. These learned behaviors, or norms, aid some students while hindering others. College students are expected to seek out resources (Choy, 2001), articulate their ideas (Kemp, 1990), and to challenge their position on particular subjects (Conley, 2008) before they reach higher education. Students are expected to learn these behaviors through schooling (Thayer, 2000), in social settings (Vargas, 2004), and from their parental figures (Dennis et al., 2005). Students who do not learn these norms are more likely to be pushed to the margins and feel as if they do not belong. These feelings of marginality increase the likelihood of attrition for first-generation students (Schlossberg, 1989). First-generation students in higher education are at a disadvantage as they often do not understand the behaviors of success (Holley \& Gardner, 2012; Stanton-Salazar, 2011).

Finance. Parental education serves as the primary barrier from which other barriers for first-generation student's stem. As many first-generation students come from low-income families (Terenzini et al., 1996), the financial obstacles presented by having parents without a college education, coupled with the unfamiliarity of financing higher education, presents hurdles that their peers with college educated parents may not face. 
This obstacle may be attributed to parents of first-generation students either not saving for their child's college costs or to not fully understanding the availability or benefits of alternate means of financial support. The resultant lack of financial knowledge has been shown to serve as an obstacle (Lohfink \& Paulsen, 2005) to first-generation students completing their undergraduate studies and preventing them from matriculating to graduate school. It is important to analyze the link between socioeconomic status, the lack of parental financial knowledge, and their resultant influence on first-generation students' education (Choy, 2001; Dennis et al., 2005; Thayer, 2000; Vargas, 2004).

While the availability of additional financing options may be viewed as increasing opportunity for low-income and first-generation students, it may also serve as a potential barrier. Low-income and first-generation students are less likely to take on student loans because the system may be unfamiliar to them. As the costs of graduate education rise, so too do the burdens of paying it for low-income families (Engle \& Tinto, 2008). For example, in 1986 Pell grants covered nearly all tuition costs at the average four-year institution (Company, 2009). Since then the cost of tuition has seen a steady increase while Pell awards have remained relatively stagnant (Tierney \& Hagedorn, 2002). As tuition rose, so too did the availability of other non-need-based aid such as loans and merit scholarships (Digest of Education Statistics 2013, 2015).

Cultural Capital. Cultural capital refers to the collection of symbolic elements that are acquired through belonging to a social class. Examples include style of speech, diction, tastes, posture, clothing, mannerisms, material belongings, and credentials 
(Bourdieu, 1986). This capital is used as a form of social currency, allowing those who possess greater resources advantages over their less capital-rich peers. Similar to how the usability of financial capital differs between countries, cultural capital that is beneficial in one social milieu may not be as valuable in another (Bourdieu, 1986).

Higher education administrators have historically praised certain forms of cultural capital while disregarding others. As higher education diversifies and the values of a wider array of cultures are considered, this position has come under scrutiny (Yosso, 2005). The often unspoken norms of the accepted majority can serve as a barrier for firstgeneration students, as many come from communities that have values that may be different than those valued in higher education (A Shared Agenda, 2004; Choy, 2001).

First-generation students' graduate school experience differs from their peers who come from families in which one or more parents or familial acquaintances have attended college (Seay, et al., 2008). Gardner found that while first-generation graduate students understood that graduate school is largely self-directed and they need to learn that this new freedom requires life adjustments (S. Gardner, 2007), the loose structure of graduate school left the participants of this study feeling lost.

Cultural capital includes the recognition of a person's relationship to and within the school environment (Bourdieu, 1986). Capital has been used to explain the accesses granted to individuals and groups by processing traits associated with success in each environment. In accessing these tools in academia, students are able to better secure 
academic success, whereas gaps in capital may serve as a bar (Bourdieu, 1986; Museus \& Neville, 2012).

Understanding gaps in cultural capital can provide insight to education leaders seeking to understand what is needed when developing programs that mitigate difficulties faced by first-generation students in higher education (Bourdieu \& Locquaint, 1992). First-generation college students have been shown to experience difficulties in higher education by their inability to socially integrate (Padgett et al., 2012). While assimilation into higher education has been shown as an obstacle for first-generation undergraduates, this barrier may also hold true for first-generation graduate students. Gardner \& Holley (2011) found that because first-generation doctoral students are unfamiliar with academic communication styles they are more likely to have difficulty identifying with their peers, thus impairing their academic development. The inability to communicate fosters feelings of isolation and marginality (Schlossberg, 1989), decreasing student engagement and increasing attrition (Pascarella, Seifert, \& Whitt, 2008; Tinto, 2006). Because the attitudes, activities, and behaviors of success vary by discipline, it is important to inform first-generation students of the acceptable behaviors of their respective field (Seay et al., 2008). Understanding behaviors of a given social structure and establishing networks that inform student success by providing the resources is necessary to establish a positive identity (Hall \& Burns, 2009). Without networks of peers that can help navigate graduate school first-generation students are unlikely to persist through completion (Schlossberg, 1989; Tinto, 2006). 
Identity Development. Identity refers to an individual's understanding of their respective role in society (Sweitzer, 2009). Examining the formation of identity may be germane to the first-generation doctoral students' experiences as it focuses on individuals and their academic experiences (Hall \& Burns, 2009). Sweitzer (2009) found that doctoral students who were encouraged to establish relationships with their peers during graduate school were more successful than their peers. This encouragement fostered identification with their role and development as students. Professional relationships with both faculty and family were found to be important in helping doctoral students navigate their professional paths. For example, if students decided to pursue an academic career, there are expectant behaviors. As evidenced by Hall \& Burns (2009) the path to becoming a researcher requires a renegotiation of identity and first-generation graduate students are faced with overcoming anxiety, while at the same time trying to reformulate their beliefs about themselves.

Qualitative studies of identity reformulation in graduate students offer firsthand narratives about the personal experiences, difficulties, and coping mechanisms used by first-generation students while in graduate school. Padilla (2008) examined how racism affected Latino students and how the threat of racism posed a threat to their ethnic identity development. The findings from this study support previous research on Latino identity which suggests that when their ethnic identity is threatened, Latino students respond through one of three coping strategies: social activism, assimilation, or multiple 
group membership (Espinoza-Herold, 2003). These strategies allow Latino students to mitigate threats while maintaining cultural integrity.

Hesse-Biber and Associates (2010) found that African American female students attending predominantly White institutions demonstrated several factors that impacted self-esteem: familial racial identity, school environment, neighborhood characteristics (e.g., crime, poverty), peer groups, and other unique life events. The participants' cultural identity, which was found to be influenced by whether they were raised in a predominantly African American or White environment, had a significant influence on their body satisfaction, self-esteem, and, ultimately, their educational experience. This research supports previous findings which assert that for African Americans, self-image, even when established prior to entering higher education, is continually an issue as they are forced to take on multiple identities (Bonner, et al. 2009). If African American students are able to renegotiate their self-image they are more likely to be successful in higher education (Ewing, 1996).

The model minority myth (Chang \& Au, 2007) suggests that Asian Pacific Islander (API) groups excel academically, but this position fails under scrutiny. While some populations within this classification have shown progress, the success is not equally distributed. Some API first-generation students experience similar difficulties as other ethnic groups. Nadal and Associates (2010) found that Filipino American graduate students felt as if they were expected to complete their graduate education without familial, social, peer, or institutional support. 
The Filipino graduate students' lack of social community produced feelings of alienation. These feelings of marginality were exacerbated when Filipino students did not identify as Asian and were in programs with other Asian students.

Seay and Associates (2008) found that for first-generation White female graduate students the lack of supports significantly influenced college success. White female, firstgeneration graduate students experienced similar feelings of marginalization as other minority groups. This research adds further credence to the need to understand the impact of generational status. Had generational status not been examined for the Seay and Associates (2008) study, the resultant feelings of alienation or marginality could have been inaccurately attributed. The authors call for a collective approach to developing attrition remedies that involve both faculty and administrators.

\section{Tools That First-Generation Graduate Students use to Navigate Toward Their Doctoral Goals}

The degree to which first-generations students actualize their educational goals depends on their response to adversity (Engle \& Tinto, 2008; Warburton et al., 2001). This section will examine the tools used by first-generation students to adapt to higher education in the face of adversity:

1. Adaptation to transition.

2. Resilience. 
Adaptation to Transition. According to Piaget (Piaget, 1976), adaptation refers to an organism's response to environmental demands. This response includes both accommodation and assimilation. First-generation students entering higher education must adapt to the cultural norms of an unfamiliar environment. To support this effort institutions of higher education have developed programs to ease students transition. Transitions are the anticipated, unanticipated events that alter a person's life (Schlossberg, 1984). Schlossberg suggests that people respond differently depending on the situation (Schlossberg, 1981). While first-generation students may be able to adapt and be successful during their undergraduate years, this same student may experience difficulty in graduate school because the normative behaviors may differ by feild of study (Ishiyama \& Hopkins, 2003; Seay et al., 2008).

Using the concept of intergenerational inheritance, which refers to the inheriting of the parental educational level, Gofen (2009) suggests that some first-generation students are able to break this intergenerational cycle while others are not. Gofen argues that even in the face of the family members attempting to dissuade their educational goals, first-generation students who are successful in academia reject distraction and hold steadfast to their goals. This resilience in the face of competing values has been shown to be useful for first-generation students in education (Gullatt \& Jan, 2003; Striplin, 1999; Warburton et al., 2001).

Resilience. Resilience is a dynamic process in which first-generation students are expected to constantly adapt to their experiences in a positive way despite adversary or 
trauma (Luthar et al., 2000; Schlossberg, 1981, 1989). There are two central constructs within resilience: adversity and positive adaptation. Adversity refers to adjustment issues that are associated with negative life situations. For example, students from violent environments are less likely to adjust when compared to their peers from low violence environments. This maladjustment has been shown to negatively impact student outcomes. Positive adaptation refers to the students' knowledge of and ability to respond to adversity in a socially acceptable manner (Luthar, et al., 2000).

Students that are able to able to establish positive relationships with their peers and faculty are shown to have increased the likelihood of academic success (Luthar, et al., 2000; Pascarella et al., 2008). It is important to note that resilience is not a character trait, but a process incorporating positive responses in the face of adversity (Luthar, et al.,2000). Research is consistent that if first-generation baccalaureate students are unable to find constructive responses to feelings of isolation and marginality, their risk of attrition increases (McAlpine \& Amundsen, 2011; Schlossberg, 1989; Tinto, 1988, 1988).

\section{SUMMARY}

The evolution of American higher education has been influenced by several factors, many of which were social. One of the primary shifts is the widening of academic focus on students and an increase of attention on student development. These movements were triggered in part by the rapid social and economic changes in the US, but were also stimulated by social movements. As the US required a more technically 
trained workforce, the American higher education establishment responded by developing schools and programs to address these needs (e.g., financial aid, land grant institutions, etc.) which allowed greater numbers of students to enter higher education.

Increases in enrollment brought new challenges, including the need to attract more students from underrepresented groups and to support their success. Research on the diverse student populations has revealed several differences and has raised new questions.

Among the questions raised with increased in enrollment was how to address the problems created by this growth. California was the first state to respond by developing the Master Plan for Higher education which provided the framework for a tiered education system. While this tiered system helped to address the rapid expansion of higher education, it negatively impacted ethnic minority students, who received the brunt of these exclusionary policies.

To address demographic, socioeconomic disparity and California's decades-long shortfall of qualified educational leaders, the legislature passed Senate Bill 724, which allows the CSU system to offer professional doctorates. While receiving harsh criticism, this change was intended to increase the numbers and diversify California's educational leadership. 
Previous research categorized students by physical characteristics (e.g., race or gender) or by socioeconomic status. Recently, researchers have begun to examine how similarities between students could be used to support success for a wider array of students. Research on students who are the first in their family to attend college, or firstgeneration students is allowing schools to understand and measure inter-group nuance. Understanding generational status has allowed for an appreciation of how students across socioeconomic and gender groups can be supported.

Although there is an increased interest in understanding the experiences of students who are the first in their family to attend college, much of the research has focused on their identity, their undergraduate experience, and reasons for their attrition. This lack of understanding of the experiences of first-generation students who pursue advanced degrees impairs for schools to understand the characteristics of academically successful first-generation students who pursue advanced degrees.

This research is among the first to address this disparity by examining the characteristics, motivations and barriers for first-generations students pursuing their education doctorates in the California State University system. 


\section{Chapter 3}

\section{METHODS}

This chapter reviews the methods used in this study and is comprised of:

1. The underlying principles.

2. The study methodology.

\section{THE UNDERLYING PRINCIPLES}

This section describes the underlying principles used to undertake this study and includes:

1. A description of the research design.

2. A defense of how the research design derives logically from the initial research questions and objectives.

3. A review of the role of the researcher.

4. A review of the institutional context.

\section{The Research Design}

The research design will be described in three section:

1. The research theory.

2. The research questions.

3. The methodological approach. 
The Research Theory. Three theories framed the research design for this study: resilience, identity development, and social and cultural capital.

Resilience theory suggests that an individual's response in the face of hardship informs their success in each environment. For first-generation students faced with the difficulties of navigating an unfamiliar social setting, their response to their lack of knowledge about higher education plays an integral role in their academic failure or success.

Identity development theory suggests that academically successful first-generation students faced with being in a setting that is largely foreign are required to learn the behaviors of that environment to be successful. The learning of different normative behaviors shapes the way in which first-generation students understand themselves in relation to their peers in school and to their families. Identity development informs how they understand themselves and their relation to others. This development also provides first-generation students with the tools to seek out help when needed. 
The theory of social and cultural capital suggests that familiarity with the norms, behaviors and values of a given environment increases the likelihood of a person's success in that environment. First-generation students who can navigate to a doctorate degree are required to recognize and adapt to the norms, behaviors, and values of higher education at the undergraduate, graduate and doctoral levels. Those first-generation students who are successful find support structures that help ensure their academic success.

The Research Questions. Currently, the CSU system does not collect information about the generational status of doctoral students. Given that one of the goals of establishing the CSU Ed.D. program is to develop leaders that reflect and support the diverse needs of California's population, this study examines the characteristics, motivators and barriers of current and former first-generation students in the CSU Ed.D. program. The objective of this research is to identify this population in terms of characteristics (i.e., race, ethnicity, gender, and age) and to gain an understanding of the resources they use on their educational journey to the Ed.D. As previous studies have examined reasons for attrition for undergraduate (Billson \& Terry, 1982; Ishitani, 2006) and graduate students (S. K. Gardner \& Holley, 2011), this study seeks to understand the experiences of those first-generation students who are academically successful. To examine this population and their educational journey, this study examines the following questions: 
1. What are the characteristics, motivators and barriers of first-generations students in the CSU Ed.D. program?

2. What resources are useful in mitigating obstacles for first-generation CSU Ed.D. students as they progressed toward their degree?

The Methodological Approach. A mixed-methods approach is used in this study by utilizing both quantitative and qualitative research. Ivankova, Creswell and Stick (2006, p. 3) stated, "When used in combination, quantitative and qualitative methods complement each other and allow for a more robust analysis, taking advantage of the strengths of each." This research is designed to identify the characteristics of and examine the tools used by current and former first-generation students in CSU Ed.D. programs. This approach is a departure from the previous research that focused on reasons for attrition for first-generation students at the undergraduate and graduate levels. This study is based on the embedded mixed-methods design (Figure 3.1). This design features the collection of both qualitative and quantitative data with one data set playing a supplemental role to the other (Creswell \& Plano-Clark, 2007). The quantitative data collected in phase one informed the selection of data collected for phase two. 
Figure 3.1: Embedded Mixed Methods Design (Creswell \& Plano Clark, 2011).

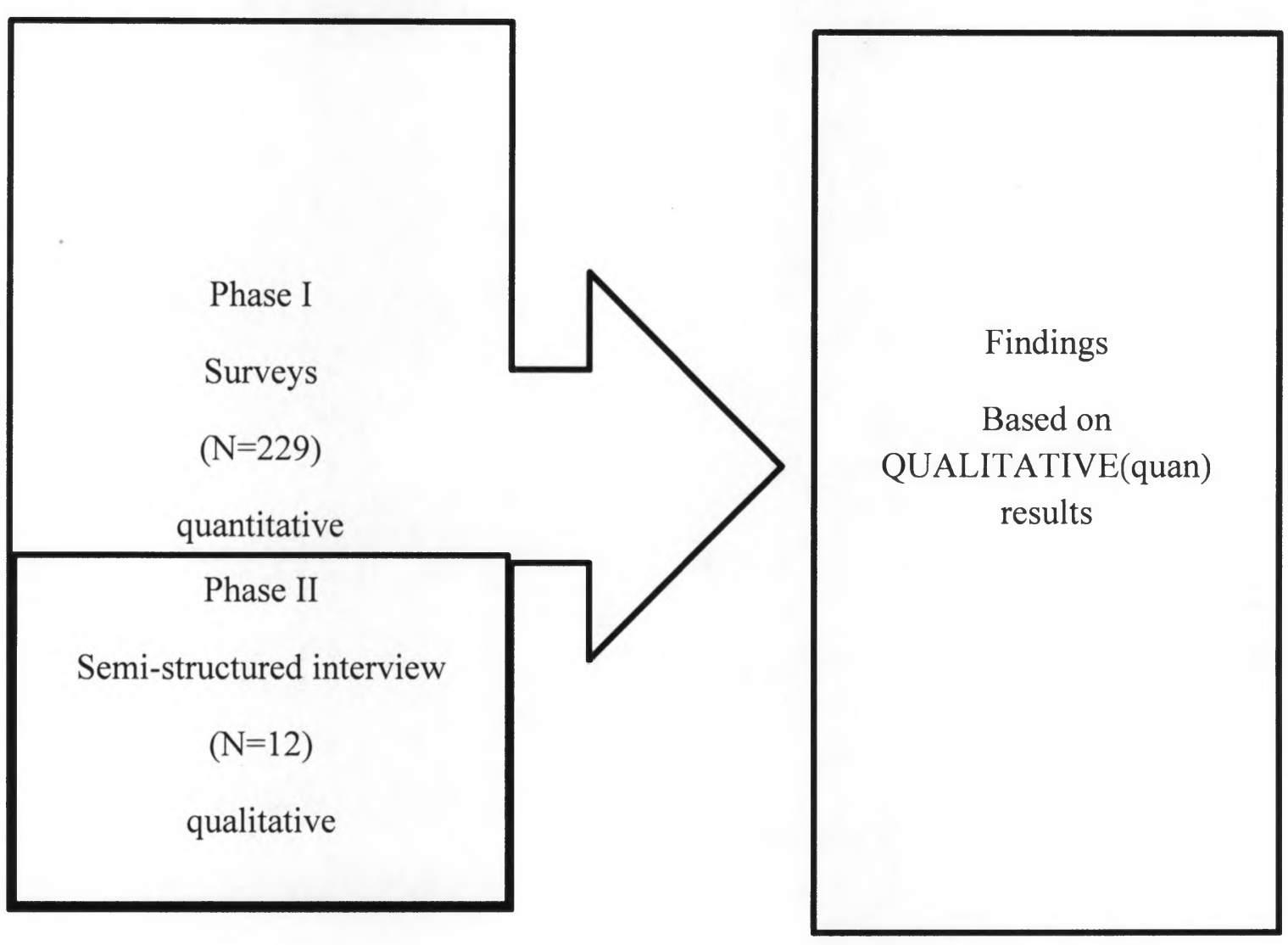


This embedded mixed-methods study was conducted in two-phases:

1. Phase 1: Consisted of a survey sent to 960 current and former CSU Ed.D. students, of which 246 responded. Of the 246 respondents, 17 surveys were discarded for insufficient information. There were a total of 229 surveys used for final analysis.

2. Phase 2: Focused on interviews of nine first-generation students and three non-first-generation students.

Figure 3.1 describes the way in which the data were collected and analyzed. Phase 1 survey were sent to all potential participants for this study $(\mathrm{N}=960)$. Data from phase 1 were analyzed and informed the development of the questions and the selection of participants for the phase 2 semi-structured interviews. The relative size of the qualitative and quantitative data in figure 3.1 represents the way in which the final analysis was weighted in the findings. While Phase I survey results provided the initial data from which participants and their experiences were understood, Phase II findings were weighted heavier for final analysis. The final data analysis is available in chapter four.

The collective term "generational status" refers to the two groups: first-generation and continuing education subjects involved in this study. The initial group of 246 survey respondents provided a pool from which the researcher selected twelve subjects to 
participate in semi-structured interviews. This participant pool was designed to capture the perspectives of current and former first-generation students from throughout the CSU Ed.D. programs and included the following characteristics:

1. Generational status.

2. Race.

3. Gender.

4. Geographic location.

\section{The Role of the Researcher}

This section details how the researcher's position as an African American, male, first-generation student who has reached the doctorate candidate level in the CSU system influenced his perceptions of the experiences of other students in a similar situation. This section will also present how his background impacted his perspective lens and research methodology. He states,

My cultural background is African American. My family and community which are largely African American have greatly influenced how I understand and engage with the world. Having family members who were geographically close, yet socioeconomically different, and hearing stories about perceptions of what it meant to be African American, increased my desire to understand resilience, identity development, and social and cultural capital. 
As far as I knew, no one in my neighborhood has graduated college. There were several people that attempted college but did not graduate. This was always curious to me as many of them had the intellect to complete their studies. Seeing this phenomenon play out over and again was a reminder to my peers and me that college was not for people from our community. It was this reality more than anything else that reminded us that we could make it without higher education.

In my household, there were no expectations nor conversations about attending college. College was a luxury that we could not afford both in terms of finance and time. I can remember my mother having a conversation with one of my middle school teachers who told her that I was "college material" and my mother responded by saying "...that sounds great, but how the hell will he afford it?" This is another example of conversations that shaped my perception of what college attendance meant, i.e., the financial hurdles coupled with my mother's incomplete information about the college process. While I knew my teachers, medical doctors, and others professionally, I do not recall having someone who I knew personally that had completed college who could teach me how to navigate to and through college. Looking back, this lack of social and cultural capital was embarrassing for me especially, when I started thinking about higher education.

Collectively, these experiences shaped the researchers experience in higher education and served as a guide for the present study. 
The researcher for this study is a third-year first-generation doctoral student studying in the CSU system. Because the researcher is in Northern California and the study required participation of subjects from all three CSU regions, most of the communication was conducted via email and video conferencing. Communicating via email and videoconference reduced travel expense and participant response time.

It was understood that the researcher's bias because of being first-generation, African American male from California could skew the study. Every attempt was made to minimize researcher bias by utilizing a data coding method.

\section{The Institutional Context}

The CSU system is the largest, most diverse, and among the most affordable university systems in the country. The CSU is often referred to as the gateway institution for most students seeking a baccalaureate education in California. It is responsible for providing professional training for teachers, nurses, social workers, and engineers. This educational position makes the CSU the ideal system to examine the support structures used by successful first-generation students. Additionally, this context provides an information-rich environment for qualitative research (Patton, 1990). The CSU institutional commitment to professional development has had a tremendous impact on the education, lives, economy, and future of many educators around the world. This student population is diverse in ethnic background, training experiences and personal history. According to the most recent available data ("2016 Facts About the CSU," n.d.), more than a third of the CSU student population are first-generation students. The 
undergraduate ethnic breakdown at the time of this study is: 30 percent White, 25.6 percent Hispanic, 4.8 percent Black, .5 percent Pacific Islander, 17.1 percent Asian, and 4.3 percent listed as two or more races ("CalState Statistics Report 2012-13," n.d.). The diversity of potential participants in the CSU system increases the chances for the successful execution of this study.

\section{A Defense of How the Research Design Derives Logically from the Initial Research Questions and Objectives}

Mixed methods research allows the researcher to validate data in a variety of forms and provides answers from a number of perspectives (Creswell \& Plano Clark, 2011). This section will defend why mixed methods was used to undertake the present study.

Capturing the characteristics, motivators and barriers of current and former CSU Ed.D. students required that the researcher first develop a survey to identify this population. The CSU does not currently collect generational information for their Ed.D. students. The demographic information currently collected by CSU for its Ed.D. students includes information on students in master's and other programs. The initial stage of this research required the researcher to contact students and collect primary data for analysis.

It was reasoned that once the researcher compiled the characteristics and some initial information from the survey data, interviewing participants would provide a more robust account of participant experience. The questions for the interview were in two sections:

1. The educational expectations.

2. The process of education. 
The Educational Expectations. The section was derived from research on firstgeneration students and expectations. These questions examined the early influences on the participants' expectations about education and if those expectations shaped their desire to pursue higher education. For example, the question, "What was the expectation in your household about higher education?" was designed from research suggesting that first-generation students are less likely to have conversations about education in their homes. The question,

How was your educational journey received by your peer group? For example, were your friends supportive or did they try to sway you toward looking for work? How did you deal with this?

was designed to examine if the participants were surrounded by peers who were academically focused and, if not, how participants could stay focused.

Process of Education. The second section of interview questions focused on the participants' educational journey. The question,

Were you involved in any extra-curricular activities during your educational journey? What were they? Did participation in those activities play a role on your decision to stay in school?

examined if participation in extra-curricular activities provided participants with any social and cultural capital that would inform their desire to continue toward higher education. 
The question,

When you entered the doctoral program, did you feel separated from your family, friends, or community? If so, in what ways?

was designed to allow participants the opportunity to expound on whether their academic pursuits impacted their familial or communal relationships.

\section{STUDY METHODOLOGY}

This study was conducted in six stages:

1. Preparation.

2. The survey (Phase I).

3. The interviews (Phase II).

4. Data collection.

5. Coding the interview data and analysis.

6. Reporting the findings.

\section{Preparation.}

This section describes how the researcher prepared to undertake this study and is presented in four segments:

1. Development of the survey and questions for the interviews.

2. The institutional review board.

3. Confidentiality.

4. Narrowing the data field. 


\section{Development of Survey and Questions for Semi-Structured Interview. The} questions for the survey were derived from literature focusing on the characteristics, motivators and barriers of first-generation students. The themes derived from the literature review informed the development of the theoretical framework for this study. The themes focused on how first-generation students could exhibit resilience, and how over time, this resilience informed their identity development. One of the ways in which first-generation students could overcome academic and social obstacles, was to acclimate to the environment of higher education. This acclimation required the development of social and cultural capital that fostered their success. The combination of these experiences guided the development of the theoretical framework for this study.

Questions were developed to survey the following areas:

1. Familial expectations.

2. Educational expectations.

3. High school tools and resources.

4. Peer group expectations.

5. Fields of study.

6. Extra-curricular activities.

7. Process of education.

8. Dropouts.

9. Social separations.

10. Institutional supports. 
11. Career paths.

12. Networking.

Once the survey was developed, the researcher and his chair derived specific questions that probed into the educational journey of the students.

The Institutional Review Board. Application for approval was made to the university Institutional Review Board and research commenced upon approval of that body. The anticipated potential for harm to the individual was minimal. Information collected from this study is maintained in a secure repository. All reasonable efforts to maintain complete subject confidentiality were in place and enforced. Subject identifiers were eliminated from all reports and communications. Pseudonyms were assigned for the case study portion of the study.

Confidentiality. There were two levels of confidentiality maintained during the survey stage:

1. The initial level of confidentiality was maintained by having program directors send the initial query to their current and former students which prevented the researcher from collecting contact information from potentially uninterested parties.

2. The second level of confidentiality offered students the option of not having their contact information stored.

Participants were given the option of only providing their names and contact information if they were willing and interested in participating in a follow up interview 
and a drawing for one of four $\$ 25$ Visa gift cards.

Narrowing the data field. A set of descriptive statistics was drawn from the quantitative survey data to gauge the frequency and strength of generational status as it related to participant characteristics (i.e., race, age, gender, and ethnicity).

Socioeconomic data would have been outside the scope of this research as it would have required information that would not have been easily verifiable, so this information was not requested.

\section{The Survey (Phase I)}

The initial solicitation email was sent to program directors requesting that they send an email to their current and former Ed.D students. Included in the email was the text that included a link to the "Understanding The Experiences of Students on Their Journey Toward the Education Doctorate in The California State University Education Doctorate" survey (Appendix III). The embedded link directed responders to the survey, which was administered by Qualtrics. Qualtrics is a survey and analysis software offered free to students through the CSU system.

\section{The Interviews (Phase II)}

The methodology of the semi-structured interviews is presented in two sections:

1. The selection of participants.

2. The interview process.

The Selection of Participants. The participants for this study were drawn from current and former education doctoral students in the CSU system. Table 3.1 illustrates the 
number of surveys used for this study.

Table 3.1. Survey response rates $(\mathrm{N}=960)$.

\begin{tabular}{|l|c|c|}
\hline & $\begin{array}{l}\text { Number of Survey } \\
\text { Used for Study }\end{array}$ & $\begin{array}{c}\text { Percentage of Returned Surveys } \\
\text { used in Final Analysis }\end{array}$ \\
\hline $\begin{array}{l}\text { Number of surveys } \\
\text { returned }\end{array}$ & 246 & $100 \%$ \\
\hline $\begin{array}{l}\text { Number of surveys } \\
\text { discarded }\end{array}$ & 17 & $7 \%$ \\
\hline $\begin{array}{l}\text { Number of surveys used } \\
\text { in the final analysis }\end{array}$ & 229 & $78 \%$ \\
\hline $\begin{array}{l}\text { Number of surveys that } \\
\text { granted interview }\end{array}$ & 169 & $4.9 \%$ \\
\hline $\begin{array}{l}\text { Total number selected for } \\
\text { interviews }\end{array}$ & 12 & \\
\hline
\end{tabular}

Interviews were conducted with twelve subjects drawn from the survey pool based on four criteria:

1. Generational status. 
2. Ethnicity.

3. Geographic location.

4. Desire to participate.

Generational status. This study was particularly interested in the characteristics, motivators and barriers of first-generation students in CSU Ed.D programs. Nine firstgeneration students and three continuing education students were chosen for follow-up interviews. The inclusion of continuing education students allowed the researcher to parse out those experiences that were true for all students and thereby gain a more accurate understanding of the experiences specific to first-generation students.

Allowing the participants to choose the educational level of each parental figure allowed for an additional layer of analysis where first-generation students would be more likely to come from non-traditional households (e.g., single parent or living with grandparents or stepparents).

To determine the generational status, participants were asked to respond to the following questions:

1. What is the highest level of education completed by the female parental figure in your household growing up (e.g., mother, grandmother, stepmother)?

2. What is the highest level of education completed by the male parental figure in your household growing up (e.g., father, grandfather, stepfather)?

The following options were provided to determine the generational status of the 
participant's "female parental figure:"

1. $8^{\text {th }}$ grade or below.

2. High school.

3. Bachelor's degree.

4. Graduate degree or beyond.

5. No female parental figure.

The following options were provided to determine the generational status of the participant's "male parental figure:"

1. $8^{\text {th }}$ grade or below.

2. High school.

3. Bachelor's degree.

4. Graduate degree or beyond.

5. No male parental figure.

To determine the participant's generational status, survey responses were placed into two categories:

1. High school or below, which included high school and 8th grade or below, and labeled "first-generation."

2. College, graduate or above, combined into the "non-first-generation" group. In cases where the respondents answered that they did not have either a male or female parental figure, the researcher determined generational status based on the 
educational level of their existing parental figure.

The categorization used for the final analysis was:

1. First-generation: $8^{\text {th }}$ grade or below, high school.

2. Continuing education: Bachelor's degree, graduate degree or beyond.

Ethnicity. The experiences of first-generation students may be influenced by ethnicity and therefore the researcher reasoned that the voices of the various ethnic groups should be examined. Three participants from each of the final categorizations for ethnicity were included for a total of twelve subjects. Subjects were considered for interview if they responded that they were interested in participating in a follow-up interview and responded positively and timely to the follow-up email solicitation (Appendix 2). Once this group was finalized, the groupings were based on the number of available participants from each group.

The options for ethnicity were taken from the CSU website to ensure that the survey captured the most current representation of ethnic groups. The survey included ten categories:

1. Native American, Alaskan Native.

2. African American.

3. Chicano, Mexican American.

4. Other Latino.

5. Asian.

6. Filipino. 
7. Hawaiian/Pacific Islander.

8. White, Non-Latino.

9. Multiethnic.

10. Unknown.

Including the representative voice of each of the ethnic categories allowed for a more robust study as it provided an additional layer of analysis on the experiences of firstgeneration students. Due to the small number participants and lack of interest in participating in a follow up interview, participants from the multi-ethnic and unknown categories were not included in the final interview group. Further, there were only two Chicano/ Mexican American subjects that responded to the email solicitation for followup interview (1 male and 1 female). An additional White first-generation participant was added to this group.

Due to the low response rate, some of the categories were combined to provide a more representative sample. The categories for final analysis were:

1. Asian: Asian, Filipino, Hawaiian/Pacific Islander.

2. African American.

3. Latino/Hispanic: Native American, Chicano/Mexican, other Latino.

4. White, Non-Latino.

5. Multiethnic.

Geographic Location. It was a goal of this study to examine the characteristics, motivators and barriers of first-generation students in the CSU system, which required 
that representation from each of the three regions as defined by the CSU (i.e., Northern, Central, Southern). The researcher reasoned that the experiences of first-generation students may be influenced by geographic region, as the surrounding area my influence the desire to pursue higher education. For example, would students from rural areas be less likely to pursue higher education than their urban peers?

Three participants from each of the regions were included. Consideration was based on both participant interest in an interview which was asked in the survey and participant availability which was requested in a follow up solicitation email (Appendix 2). Subjects were also considered in relation to the ethnic representation from each of the ethnic categorizations developed in the second criteria. Once the grouping from the previous criteria were finalized, the researcher determined the groupings of this section based on the number of available participants (table 3.2). 
Table 3.2. Interview Subjects.

\begin{tabular}{|c|c|c|c|}
\hline Name & Ethnicity & Gender & Region \\
\hline 1. May Yang L. & Asian & Female & Central \\
\hline 2. Yolanda M. & White & Female & Central \\
\hline 3. Antonio $\mathrm{C}$. & Latino & Male & Central \\
\hline 4. Joselyn B. & Black & Female & Northern \\
\hline 5. Khalil P. & Black & Male & Northern \\
\hline 6. Terri V.K. & Asian & Female & Northern \\
\hline 7. Morgan $\mathrm{Q}$. & Asian & Male & Northern \\
\hline 8. Ellis D. & White & Female & Northern \\
\hline
\end{tabular}




\begin{tabular}{|c|l|l|l|}
\hline 9. Hannah L. & Latino & Female & Southern \\
\hline 10. Lillian G. & Black & Female & Southern \\
\hline 11. Taylor R. & White & Female & Southern \\
\hline 12. Jay A. & White & Male & Southern \\
\hline
\end{tabular}

One of the complications for finalizing representation of participants from each of the geographic regions was not having a variable in the survey asking which home institution the subject studied at. It was initially reasoned that the email address would provide institutional information. It was later realized that some students used personal email addresses which prevented the researcher from determining the institution at which they studied. It was also reasoned that the email address was not the most reliable verification of where a student studied. Even in scenarios where the participants used a CSU email address, they could have studied at one school and be attending or working for another school in a different region. This was especially true for participants who had already graduated. This oversight was one of the limitations for reliability of the regional criteria.

Desire to Participate. The fourth criterion was a desire to participate. A "yes" or "no" question on the initial selection survey was used to identify subjects willing to be considered for the second phase of this study. 
The Interview Process. The twelve candidates or interviews were selected based on the four standards defined in the previous sections and contacted by e-mail for scheduling an interview. To maintain consistency, interviews were conducted via Skype, Facetime or Google Hangout. These platforms were used to normalize the interview experience, minimize cost for the researcher, and to allow for the inclusion of participants from the three regions in a timely manner. Interviews were scheduled at negotiated times to maximize privacy, focus and comfort for the subjects.

Interview questions were based on issues, concepts and ideas suggested in the literature. They centered on family expectations about higher education, fields of study, career paths, processes of education, decisions for advanced study, extra-curricular activities, and institutional supports used during the educational journey. To enrich the data the initial interview questions were used as a stimulus for subjects to explore areas not specifically mentioned in the interview document (Appendix 3). The duration of the initial interviews was 45 to 140 minutes. Contact was made by email to clarify responses.

Twelve subjects participated in semi-structured interviews conducted by video conferencing and electronically recorded by the researcher. As stated by Merriam (1998, p. 6),

Qualitative researchers are interested in understanding the meaning people have constructed, that is, how they make sense of their world and the experiences they have in the world. 
Qualitative methodology provides a structure in which trends emerge from data that are not influenced by researcher hypothesis or pre-conceptions (Golafshani, 2003). As opposed to being solely numeric, qualitative data are descriptive and afford the space for attributions to be expressed in narrative.

This phase of the study also included a multi-case comparison component. Six cases were compared as one set, thus providing the most accurate picture from the data and resulted in an increase in precision, validity and stability (Miles \& Huberman, 1994).

\section{Data Collection}

The "Understanding The Experiences of Students on Their Journey Toward the Education Doctorate in The California State University Education Doctorate" survey provided a general picture of all the subjects regarding participant generational status, personal demographics and educational journey.

The semi-structured interview (Appendix III) was used to establish informant history, attitudes and beliefs. This semi-structured interview (Creswell, 2005) was recorded for later transcription and analysis. Hand written notes were taken and followup questions were asked as necessary.

The interview questions were presented in a chronological sequence allowing the subjects to trace the development of their educational journey as an unfolding historical narrative. The questions dealt with influences experienced because of environmental, social and institutional contexts experienced by the interview subjects (Appendix 2). 
Field notes were maintained and transcribed to verify the accuracy of the interview transcriptions and added data not captured. For example, a field note may have contained a reference to the emotional characteristics of a subject when was not apparent in a written transcription. Field notes were categorized chronologically and annotated in relation to the timeline of the recorded interview. This provided reference points to compare field notes to interview data in a precise manner.

Questions that developed from the analysis of the initial interviews were clarified by e-mail. It was necessary to acquire clarifying data from all twelve cases.

The questions for the interview focused on the participants' educational expectations and processes of education. For example, one first-generation respondent stated that he was raised in an environment that was highly focused on pursuing higher education. The interview clarified how being Chinese and living in an area pushed his parents to place him in a private school that provided a more academic environment.

\section{Coding the Interview Data}

Codes are the labels that are assigned to provide symbolic meaning to the descriptive or inferential information gathered during a study (Miles, Huberman, \& Saldaña, 2014). Data for this study were coded in two cycles:

1. In vivo coding.

2. Pattern coding.

In Vivo Coding. According to Miles, Huberman, \& Saldana (2014), In vivo coding is useful for beginning qualitative researchers as the codes derive from the participants 
own language. This language “...may include folk or indigenous terms of a particular culture, subculture or microculture to suggest the existence of the groups' cultural categories" (Miles et al., 2014, p. 74). As the first cycle codes originated from the transcriptions, it allowed the researcher to prioritize and honor the participants' voices using their own words.

This first cycle coding produced a list that was placed in a matrix for further grouping. This grouping allowed the researcher to develop definitions for the codes that were used to further condense the first round of codes. Once the initial group of codes were defined and grouped, they were used to guide the second round of coding.

Pattern Coding. According to Miles, Huberman, \& Saldana (2014) pattern coding is used in four primary functions in qualitative analysis:

1. To condense large amounts of data into more manageable units.

2. To involve the researcher in the analysis during data collection so that later fieldwork can increase the focus.

3. To allow the researcher to develop a cognitive map.

4. To lay the groundwork for cross-case analysis by producing common themes.

To condense large amounts of data into more manageable units. Once the data was placed into the matrix and defined, the researcher placed similar threads of code together and recoded the information. The recoding involved capturing commonalities between the groups produced in the first cycle coding and developing new codes to 
represent them.

To involve the researcher in the analysis during data collection, so that later fieldwork can increase the focus. During data collection, the researcher developed field notes. The field notes were later transcribed into a data memo that included initial patterns that would later guide the development of codes for the first cycle of coding. The researcher could identify feelings and emotions that would later inform the development of the first cycle of codes.

Allow the researcher to develop a cognitive map. Once the researcher could develop themes, they were placed into thematic groups which were used for the final analysis.

To lay the groundwork for cross-case analysis by producing common themes. For the present study, cross-case analysis was used to accumulate case knowledge. The comparison and contrasting of cases allowed the researcher to produce new knowledge. Identification and Reporting the Findings

Findings from the analysis in Phase I and Phase II are reported in Chapter 4. Included in the analysis are answers to each of the research questions using the embedded mixed method. Such a method which can increase the reliability and allowed preliminary generalizations to be made regarding the reasons why and how these first-generation participants can successfully navigate toward the educational doctorate. 


\section{Chapter 4}

\section{RESULTS}

This chapter presents the findings of this study and is comprised of:

1. The analysis of the Phase 1 survey responses.

2. The analysis of the Phase 2 semi-structured interviews.

\section{The Analysis of Phase 1 Survey Responses}

Of the 960 surveys distributed, 246 were returned. Seventeen (2\%) surveys were discarded for lack of adequate responses to prompts. The remaining 229 (93\%) completed surveys were used for the analysis.

The survey instrument included six sections:

1. Student demographic information.

2. Educational experiences.

3. Student motivators.

4. Institutional resources.

5. Educational barriers.

6. Requests for interviews.

Participants were not required to provide responses for every prompt and thus some tables may present different numbers for the total population. 
Student demographic information. The first section of the survey identified participant demographic information. Questions in this category allowed the researcher to identify:

1. Age.

2. Ethnicity.

3. Gender.

4. Generational status.

Age. Table 4.1 presents the age ranges for the study participants. Of the 105 firstgeneration respondents to this prompt, 14 (13.3\%) were at or below the age of $30 ; 55$ (52.4\%) were between the ages of 31 and $45 ; 32(30.5 \%)$ were between the ages of 46 and 60; and $4(3.8 \%)$ were 60 years or older.

Of the 107 non-first-generation respondents to this prompt, $9(8.4 \%)$ were at or below the age of $30 ; 56(52.3 \%)$ were between the ages of 31 and $45 ; 40(37.4 \%)$ were between the ages of 46 and 60 ; and $2(1.9 \%)$ were 60 years or older.

Chi Square analysis found that age and generational status were independent for the present study. 
Table 4.1. Participant age distribution.

\begin{tabular}{|l|l|r|r|r|}
\hline \multirow{2}{*}{ Age } & & \multicolumn{2}{|c|}{ Generational status } & \\
\cline { 3 - 5 } & & first-generation & non-first-generation & \multirow{2}{*}{ Total } \\
\hline 30 or under & Count & 14 & 9 & 23 \\
& $\%$ within column & $13.3 \%$ & $8.4 \%$ & $10.8 \%$ \\
\hline $31-45$ & Count & 55 & 56 & 111 \\
& $\%$ within column & $52.4 \%$ & $52.3 \%$ & $52.4 \%$ \\
\hline $46-60$ & Count & 32 & 40 & 72 \\
& $\%$ within column & $30.5 \%$ & $37.4 \%$ & $34.0 \%$ \\
\hline over 60 & Count & 4 & 2 & 6 \\
& $\%$ within column & $3.8 \%$ & $1.9 \%$ & $2.8 \%$ \\
\hline Total & Count & 105 & 107 & 212 \\
& $\%$ within column & $100.0 \%$ & $100.0 \%$ & $100.0 \%$ \\
\hline
\end{tabular}

$\left(\chi^{2}=2.63, \mathrm{df}=3, \mathrm{p}<0.5\right)$

Ethnicity. Table 4.2 presents the participants' responses to the question of which option best identifies their ethnic group and includes the list of variables before they were re-categorized. Of the 107 first-generation respondents to this prompt, $0(0 \%)$ was Native American or Alaskan American; 19 (17.8\%) were African American; 17 (15.9\%) were Chicano or Mexican American; 7 (6.5\%) were Other Latino; 15 (14\%) were Asian; 1 
$(0.9 \%)$ was Filipino; $42(39.3 \%)$ were White or Non-Latino; and $6(5.6 \%)$ were Multiethnic.

Of the 107 non-first-generation respondents to this prompt, $2(1.9 \%)$ were Native American or Alaskan Native; 9 (8.4\%) were African American; 9 (8.4\%) were Chicano or Mexican American; 2 (1.9\%) were Other Latino; 12 (11.2\%) were Asian; 1 (0.9\%) was Filipino; 61 (57\%) were White or Non-Latino; and $11(10.3 \%)$ were Multiethnic.

Chi Square analysis found that ethnicity and generational status were dependent for the present study. 
Table 4.2. Participant ethnicity.

\begin{tabular}{|c|c|c|c|}
\hline $\begin{array}{l}\text { Which of the following choices best } \\
\text { identifies your ethnic group? }\end{array}$ & & $\begin{array}{l}\begin{array}{l}\text { Generational } \\
\text { status }\end{array} \\
\text { first-generation }\end{array}$ & $\begin{array}{l}\text { Total for all } \\
\text { Respondents }\end{array}$ \\
\hline Native American, Alaskan Native & $\begin{array}{l}\text { Count } \\
\% \text { within } \\
\text { column }\end{array}$ & $\begin{array}{r}0 \\
0.0 \%\end{array}$ & $\begin{array}{r}2 \\
0.9 \%\end{array}$ \\
\hline African American & $\begin{array}{l}\text { Count } \\
\% \text { within } \\
\text { column }\end{array}$ & $\begin{array}{r}19 \\
17.8 \%\end{array}$ & $\begin{array}{r}28 \\
13.1 \%\end{array}$ \\
\hline Chicano, Mexican American & $\begin{array}{l}\text { Count } \\
\% \text { within } \\
\text { column }\end{array}$ & $\begin{array}{r}17 \\
15.9 \%\end{array}$ & $\begin{array}{r}26 \\
12.1 \%\end{array}$ \\
\hline Other Latino & $\begin{array}{l}\text { Count } \\
\% \text { within } \\
\text { column }\end{array}$ & $\begin{array}{r}7 \\
6.5 \%\end{array}$ & $\begin{array}{r}9 \\
4.2 \%\end{array}$ \\
\hline Asian & $\begin{array}{l}\text { Count } \\
\% \text { within } \\
\text { column }\end{array}$ & $\begin{array}{r}15 \\
14.0 \%\end{array}$ & $\begin{array}{r}27 \\
12.6 \%\end{array}$ \\
\hline Filipino & $\begin{array}{l}\text { Count } \\
\% \text { within } \\
\text { column }\end{array}$ & 1 & $\begin{array}{r}2 \\
0.9 \%\end{array}$ \\
\hline White, Non-Latino & Count & 42 & 103 \\
\hline
\end{tabular}




\begin{tabular}{|l|l|r|r|}
\hline & $\begin{array}{l}\% \text { within } \\
\text { column }\end{array}$ & $39.3 \%$ & $48.1 \%$ \\
\hline Multiethnic & $\begin{array}{l}\text { Count } \\
\% \text { within } \\
\text { column }\end{array}$ & $5.6 \%$ & 17 \\
\hline Total & $\begin{array}{l}\text { Count } \\
\% \text { within } \\
\text { column }\end{array}$ & $100.0 \%$ & $7.9 \%$ \\
\hline
\end{tabular}

$\left(\chi^{2}=16.12, \mathrm{df}=7, \mathrm{p}<0.05\right)$

Table 4.3 presents the participants' responses to the question of which option best identifies their ethnic group after they were grouped. Of the 107 first-generation respondents to this prompt, $13(12.1 \%)$ were Hispanic or Latino; 9 (8.4\%) were African American; 13 (12.1\%) were Asian; 61 (57\%) were White; and 11 (10.3\%) were Multiethnic.

Of the 107 non-first-generation respondents to this prompt, 13 (12.1\%) were Hispanic or Latino; 9 (8.4\%) were African American; 13 (12.1\%) were Asian; 61 (57\%) were White; and 11 (10.3\%) were Multiethnic.

Chi Square analysis found that ethnicity and generational status were dependent for the present study. 
Table 4.3. Ethnicity grouped

\begin{tabular}{|c|c|c|c|c|}
\hline \multirow[b]{2}{*}{ Ethnicity } & & \multicolumn{2}{|c|}{ Generational status } & \multirow[b]{2}{*}{ Total } \\
\hline & & first-generation & Non-first-generation & \\
\hline Hispanic/Latino & $\begin{array}{l}\text { Count } \\
\% \text { within column }\end{array}$ & $\begin{array}{r}24 \\
22.4 \%\end{array}$ & $\begin{array}{r}13 \\
12.1 \%\end{array}$ & $\begin{array}{r}37 \\
17.3 \%\end{array}$ \\
\hline African American & $\begin{array}{l}\text { Count } \\
\% \text { within column }\end{array}$ & $\begin{array}{r}19 \\
17.8 \%\end{array}$ & $\begin{array}{r}9 \\
8.4 \%\end{array}$ & $\begin{array}{r}28 \\
13.1 \%\end{array}$ \\
\hline Asian & $\begin{array}{l}\text { Count } \\
\% \text { within column }\end{array}$ & $\begin{array}{r}16 \\
15.0 \%\end{array}$ & $\begin{array}{r}13 \\
12.1 \%\end{array}$ & $\begin{array}{r}29 \\
13.6 \%\end{array}$ \\
\hline White & $\begin{array}{l}\text { Count } \\
\% \text { within column }\end{array}$ & $\begin{array}{r}42 \\
39.3 \%\end{array}$ & $\begin{array}{r}61 \\
57.0 \%\end{array}$ & $\begin{array}{r}103 \\
48.1 \%\end{array}$ \\
\hline Multiethnic & $\begin{array}{l}\text { Count } \\
\% \text { within column }\end{array}$ & $\begin{array}{r}6 \\
5.6 \%\end{array}$ & $\begin{array}{r}11 \\
10.3 \%\end{array}$ & $\begin{array}{r}17 \\
7.9 \%\end{array}$ \\
\hline Total & $\begin{array}{l}\text { Count } \\
\% \text { within column }\end{array}$ & $\begin{array}{r}107 \\
100.0 \%\end{array}$ & $\begin{array}{r}107 \\
100.0 \%\end{array}$ & $\begin{array}{r}214 \\
100.0 \%\end{array}$ \\
\hline
\end{tabular}

$\left(\chi^{2}=12.13, \mathrm{df}=4, \mathrm{p}<0.05\right)$ 
Gender. Table 4.4 presents the participants' responses to the question of how they identified their gender. Of the 107 first-generation respondents to this prompt, $35(32.7 \%)$ identified themselves as male; $72(67.3 \%)$ identified themselves as female; and $0(0 \%)$ identified themselves as trans-gender.

Of the 109 non-first-generation respondents to this prompt, 25 (22.9\%) identified themselves as male; $83(76.1 \%)$ identified themselves as female; and $1(0.9 \%)$ identified themselves as transgender.

Table 4.5 presents the total (i.e., first-generation and non-first-generation) gender population and percentages for all survey respondents.

Chi Square analysis found that gender and generational status were independent for the present study. 
Table 4.4. Gender breakdown of first-generation and non-first-generation respondents.

\begin{tabular}{|c|c|c|c|c|}
\hline \multirow{2}{*}{$\begin{array}{c}\text { How would you identify } \\
\text { your gender? }\end{array}$} & & & \multicolumn{2}{|c|}{ Generational status } \\
\hline & & & $\begin{array}{l}\text { first- } \\
\text { generation }\end{array}$ & $\begin{array}{l}\text { non-first- } \\
\text { generation }\end{array}$ \\
\hline & Male & $\begin{array}{l}\text { Count } \\
\% \text { within } \\
\text { column }\end{array}$ & $\begin{array}{r}35 \\
32.7 \%\end{array}$ & $\begin{array}{r}25 \\
22.9 \%\end{array}$ \\
\hline & Female & $\begin{array}{l}\text { Count } \\
\text { \% within } \\
\text { column }\end{array}$ & $\begin{array}{r}72 \\
67.3 \%\end{array}$ & $\begin{array}{r}83 \\
76.1 \%\end{array}$ \\
\hline & Transgender & $\begin{array}{l}\text { Count } \\
\% \text { within } \\
\text { column }\end{array}$ & $\begin{array}{r}0 \\
0.0 \%\end{array}$ & $\begin{array}{r}1 \\
0.9 \%\end{array}$ \\
\hline Total & & $\begin{array}{l}\text { Count } \\
\% \text { within } \\
\text { column }\end{array}$ & $\begin{array}{r}107 \\
100.0 \%\end{array}$ & $\begin{array}{r}109 \\
100.0 \%\end{array}$ \\
\hline
\end{tabular}


Table 4.5. Gender breakdown of total respondent population.

\begin{tabular}{|l|l|r|}
\hline How would you identify your gender? & & Total \\
\hline Male & Count & $27.8 \%$ \\
\hline Female & $\%$ within column & 155 \\
& Count & $71.8 \%$ \\
\hline Transgender & Count & 1 \\
& \% within column & $0.5 \%$ \\
\hline Total & Count & 216 \\
\hline
\end{tabular}

$\left(\chi^{2}=3.43, \mathrm{df}=2, \mathrm{p}<0.2\right)$ 
Generational-status. The independent variable for this study was generational status. As the questions focused on the highest level of education for the female and male parental figures, no cross tabulation was created.

Educational experiences. The second section of the survey focused on participants' educational experiences.

Table 4.6 presents the participants' responses to the question of whether they attended community college before attending a four-year institution. Of the 107 firstgeneration respondents to this prompt, $51(47.7 \%)$ stated that they attended community college before attending a four-year institution and $56(52.3 \%)$ stated that they did not.

Of the 109 non-first-generational respondents to this prompt, $43(39.4 \%)$ stated that they had attended community college before attending a four-year institution and 66 $(60.6 \%)$ stated that they did not.

Chi Square analysis found that attending community college and generational status were dependent for the present study. 
Table 4.6. Community college attendance.

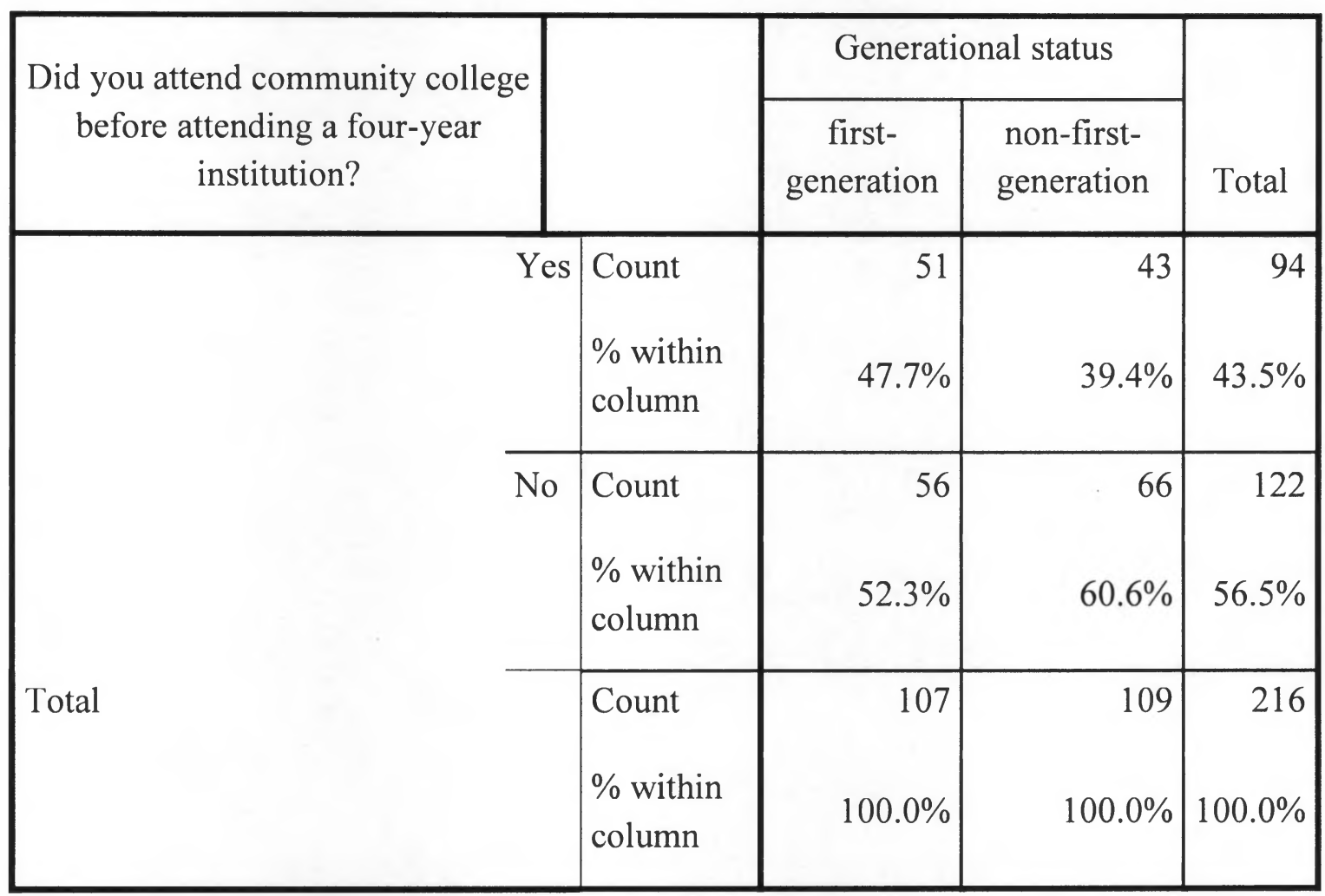

$\left(\chi^{2}=1.48, \mathrm{df}=1, \mathrm{p}<0.3\right)$

Table 4.7 presents the participant responses to the question of whether they were involved in any college transition programs before starting college (e.g., Upward Bound, Summer Bridge, etc.).

Of the 107 first-generation respondents to this prompt, $12(11.2 \%)$ stated that they participated in a college transition program before starting college and $95(88.8 \%)$ stated that they did not. 
Of the 109 non-first-generation respondents to this prompt, $7(6.4 \%)$ stated that they were involved in college transition programs before starting college and 102 $(93.6 \%)$ stated that they were not.

Chi Square analysis found that participation in college transition programs before college and generational status were independent for the present study.

Table 4.7. Participant involvement in college transition programs.

\begin{tabular}{|c|c|c|c|c|}
\hline \multirow{2}{*}{$\begin{array}{c}\text { Were you involved in any college } \\
\text { transition programs before starting } \\
\text { college? }\end{array}$} & & \multicolumn{2}{|c|}{ Generational status } & \multirow[b]{2}{*}{ Total } \\
\hline & & $\begin{array}{c}\text { first- } \\
\text { generation }\end{array}$ & $\begin{array}{l}\text { non-first- } \\
\text { generation }\end{array}$ & \\
\hline Yes & $\begin{array}{l}\text { Count } \\
\text { \% within } \\
\text { column }\end{array}$ & 12 & 7 & $\begin{array}{r}19 \\
8.8 \%\end{array}$ \\
\hline No & $\begin{array}{l}\text { Count } \\
\% \text { within } \\
\text { column }\end{array}$ & $\begin{array}{r}95 \\
88.8 \%\end{array}$ & $\begin{array}{r}102 \\
93.6 \%\end{array}$ & $\begin{array}{r}197 \\
91.2 \%\end{array}$ \\
\hline Total & $\begin{array}{l}\text { Count } \\
\text { \% within } \\
\text { column }\end{array}$ & 107 & 109 & 216 \\
\hline
\end{tabular}

$\left(\chi^{2}=1.55, \mathrm{df}=1, \mathrm{p}<0.5\right)$ 
Table 4.8 presents the participants' responses to the question of whether they were involved in any college transition programs during college (e.g., Equal Opportunity Programs and Services (EOPS), TRiO). Of the 107 first-generation respondents to this prompt, $22(20.6 \%)$ stated that they were involved in college transition programs during college and $85(79.4 \%)$ stated that they were not.

Of the 109 non-first-generation respondents to this prompt, $12(11 \%)$ stated that they were involved in college transition programs during college and $97(89 \%)$ stated that they were not.

Chi Square analysis found that participant involvement in college transition programs during college and generational status were independent for the present study. 
Table 4.8. Involvement in college transition programs in college.

\begin{tabular}{|c|c|c|c|c|}
\hline \multirow[b]{2}{*}{$\begin{array}{c}\text { Were you involved in any college transition } \\
\text { programs during college? }\end{array}$} & & \multicolumn{2}{|c|}{ Generational status } & \multirow[b]{2}{*}{ Total } \\
\hline & & $\begin{array}{c}\text { first- } \\
\text { generation }\end{array}$ & $\begin{array}{l}\text { non-first- } \\
\text { generation }\end{array}$ & \\
\hline Yes & $\begin{array}{l}\text { Count } \\
\% \\
\text { within } \\
\text { column }\end{array}$ & 22 & 12 & $\begin{array}{r}34 \\
15.7 \%\end{array}$ \\
\hline No & $\begin{array}{l}\text { Count } \\
\% \\
\text { within } \\
\text { column }\end{array}$ & 85 & 97 & $\begin{array}{r}182 \\
84.3 \%\end{array}$ \\
\hline Total & $\begin{array}{l}\text { Count } \\
\% \\
\text { within } \\
\text { column }\end{array}$ & 107 & 109 & 216 \\
\hline
\end{tabular}

$\left(\chi^{2}=3.71, \mathrm{df}=1, \mathrm{p}<0.6\right)$

Table 4.9 presents the participants' responses to whether they worked more than 20 hours per week (excluding work study and internships) on a consistent basis as an undergraduate. Of the 107 first-generation respondents to this prompt, $88(82.2 \%)$ stated that they worked more than 20 hours per week on a consistent basis as an undergraduate and $19(17.8 \%)$ stated that they did not. 
Of the 109 non-first-generation respondents to this prompt, 75 (68.8\%) stated that they had worked more than 20 hours per week (excluding work study and internships) on a consistent basis as an undergraduate and 34 (31.2 percent) stated that they did not.

Chi Square analysis found that participants working 20 or more hours per week as an undergraduate and generational status were dependent for the present study.

Table 4.9. Worked 20 or more hours per week as an undergraduate.

\begin{tabular}{|c|c|c|c|c|}
\hline \multirow[b]{2}{*}{$\begin{array}{c}\text { Did you work at least } 20 \\
\text { hours per week? }\end{array}$} & & \multicolumn{2}{|c|}{ Generational status } & \multirow[b]{2}{*}{ Total } \\
\hline & & $\begin{array}{l}\text { first- } \\
\text { generation }\end{array}$ & $\begin{array}{l}\text { non-first- } \\
\text { generation }\end{array}$ & \\
\hline $\mathrm{Ye}$ & $\begin{array}{l}\text { Count } \\
\% \text { within } \\
\text { column }\end{array}$ & $\begin{array}{r}88 \\
82.2 \%\end{array}$ & $\begin{array}{r}75 \\
68.8 \%\end{array}$ & $\begin{array}{r}163 \\
75.5 \%\end{array}$ \\
\hline $\mathrm{No}$ & $\begin{array}{l}\text { Count } \\
\text { \% within } \\
\text { column }\end{array}$ & $\begin{array}{r}19 \\
17.8 \%\end{array}$ & $\begin{array}{r}34 \\
31.2 \%\end{array}$ & $\begin{array}{r}53 \\
24.5 \%\end{array}$ \\
\hline Total & $\begin{array}{l}\text { Count } \\
\% \text { within } \\
\text { column }\end{array}$ & 107 & $\begin{array}{r}109 \\
100.0 \%\end{array}$ & $\begin{array}{r}216 \\
100.0 \%\end{array}$ \\
\hline
\end{tabular}

$\left(\chi^{2}=5.26, \mathrm{df}=1, \mathrm{p}<0.05\right)$ 
Table 4.10 presents the participants' responses to the question of whether they received financial support from their family when they were undergraduate students. Of the 107 first-generation respondents to this prompt, $37(34.6 \%)$ stated that they received financial support from their family when they were undergraduate students and 70 $(65.4 \%)$ stated that they did not.

Of the 108 non-first-generation respondents to this prompt, $64(59.3 \%)$ stated that they had received financial support from their family while they were an undergraduate student and $44(40.7 \%)$ stated that they did not.

Chi Square analysis found that participant receipt of financial support from their family as an undergraduate and generational status were dependent for the present study. 
Table 4.10. Received financial support from family as an undergraduate.

\begin{tabular}{|c|c|c|c|c|}
\hline \multirow{2}{*}{$\begin{array}{l}\text { Did you receive financial support } \\
\text { from your family while you were } \\
\text { an undergraduate? }\end{array}$} & & \multicolumn{2}{|c|}{ Generational status } & \multirow[b]{2}{*}{ Total } \\
\hline & & $\begin{array}{c}\text { first- } \\
\text { generation }\end{array}$ & $\begin{array}{l}\text { non-first- } \\
\text { generation }\end{array}$ & \\
\hline Yes & $\begin{array}{l}\text { Count } \\
\% \text { within } \\
\text { column }\end{array}$ & $\begin{array}{r}37 \\
34.6 \%\end{array}$ & $\begin{array}{r}64 \\
59.3 \%\end{array}$ & $\begin{array}{r}101 \\
47.0 \%\end{array}$ \\
\hline No & $\begin{array}{l}\text { Count } \\
\% \text { within } \\
\text { column }\end{array}$ & $\begin{array}{r}70 \\
65.4 \%\end{array}$ & $\begin{array}{r}44 \\
40.7 \%\end{array}$ & $\begin{array}{r}114 \\
53.0 \%\end{array}$ \\
\hline Total & $\begin{array}{l}\text { Count } \\
\% \text { within } \\
\text { column }\end{array}$ & 107 & 108 & 215 \\
\hline
\end{tabular}

$\left(\chi^{2}=13.14, \mathrm{df}=1, \mathrm{p}<0.01\right)$

Table 4.11 presents the participant's responses to the question of whether they worked off campus as an undergraduate. Of the 107 first-generation respondents to this prompt, $84(78.5 \%)$ stated that they had worked off campus as an undergraduate and 23 $(21.5 \%)$ stated that they did not.

Of the 109 non-first-generation respondents to this prompt, $84(77.1 \%)$ stated that they did work off campus as an undergraduate student and $25(22.9 \%)$ stated that they did not. 
Chi Square analysis found that participant working off campus as an undergraduate and generational status were independent for the present study.

Table 4.11. Work off campus as an undergraduate.

\begin{tabular}{|c|c|c|c|c|}
\hline \multirow[b]{2}{*}{$\begin{array}{l}\text { Did you work off campus as an } \\
\text { undergraduate student? }\end{array}$} & & \multicolumn{2}{|c|}{ Generational status } & \multirow[b]{2}{*}{ Total } \\
\hline & & $\begin{array}{l}\text { first- } \\
\text { generation }\end{array}$ & $\begin{array}{l}\text { non-first- } \\
\text { generation }\end{array}$ & \\
\hline Yes & $\begin{array}{l}\text { Count } \\
\% \text { within } \\
\text { column }\end{array}$ & $\begin{array}{r}84 \\
78.5 \%\end{array}$ & $\begin{array}{r}84 \\
78.5 \%\end{array}$ & $\begin{array}{r}168 \\
77.8 \%\end{array}$ \\
\hline No & $\begin{array}{l}\text { Count } \\
\text { \% within } \\
\text { column }\end{array}$ & $\begin{array}{r}23 \\
21.5 \%\end{array}$ & $\begin{array}{r}25 \\
22.9 \%\end{array}$ & $\begin{array}{r}48 \\
22.2 \%\end{array}$ \\
\hline Total & $\begin{array}{l}\text { Count } \\
\text { \% within } \\
\text { column }\end{array}$ & $\begin{array}{r}107 \\
100.0 \%\end{array}$ & $\begin{array}{r}109 \\
100.0 \%\end{array}$ & $\begin{array}{r}216 \\
100.0 \%\end{array}$ \\
\hline
\end{tabular}

$\left(\chi^{2}=.07, \mathrm{df}=1, \mathrm{p}<0.8\right)$ 
Table 4.12 presents the participants' responses to the question of whether they worked at least 20 hours per week (excluding work study and internships) as a Master's degree student. Of the 107 first-generation respondents to this prompt, 95 (88.8\%) stated that they did work at least 20 hours per week (excluding work study and internships) as a Master's degree student and $12(11.2 \%)$ stated that they did not.

Of the 109 non-first-generation respondents to this prompt, $92(84.4 \%)$ stated that they did work at least 20 hours per week (excluding work study and internships) on a consistent basis as a Master's degree student and $17(15.6 \%)$ stated that they did not.

Chi Square analysis found that participant working 20 or more hours per week as a master's student and generational status were independent for the present study. 
Table 4.12. Worked at least 20 hours per week as a Master's degree student.

\begin{tabular}{|c|c|c|c|c|}
\hline \multirow{2}{*}{$\begin{array}{c}\text { Did you work at least } 20 \\
\text { hours per week as a Master's } \\
\text { student? }\end{array}$} & & \multicolumn{2}{|c|}{ Generational status } & \multirow[b]{2}{*}{ Total } \\
\hline & & $\begin{array}{c}\text { first- } \\
\text { generation }\end{array}$ & $\begin{array}{l}\text { non-first- } \\
\text { generation }\end{array}$ & \\
\hline $\mathrm{Ye}$ & $\begin{array}{l}\text { Count } \\
\% \text { within } \\
\text { column }\end{array}$ & $\begin{array}{r}95 \\
88.8 \%\end{array}$ & $\begin{array}{r}92 \\
84.4 \%\end{array}$ & $\begin{array}{r}187 \\
86.6 \%\end{array}$ \\
\hline No & $\begin{array}{l}\text { Count } \\
\% \text { within } \\
\text { column }\end{array}$ & $\begin{array}{r}12 \\
11.2 \%\end{array}$ & $\begin{array}{r}17 \\
15.6 \%\end{array}$ & $\begin{array}{r}29 \\
13.4 \%\end{array}$ \\
\hline Total & $\begin{array}{l}\text { Count } \\
\% \text { within } \\
\text { column }\end{array}$ & $\begin{array}{r}107 \\
100.0 \%\end{array}$ & $\begin{array}{r}109 \\
100.0 \%\end{array}$ & $\begin{array}{r}216 \\
100.0 \%\end{array}$ \\
\hline
\end{tabular}

$\left(\chi^{2}=.89, \mathrm{df}=1, \mathrm{p}<0.4\right)$

Table 4.13 presents the participants' response to the question of whether they received financial support from their family while they were a graduate student. Of the 107 first-generation respondents to this prompt, $10(9.3 \%)$ stated that they did receive financial support from their family during graduate school and 97 (90.7\%) stated that they did not. 
Of the 108 non-first-generation respondents to this prompt, 15 (13.9\%) stated that they had received financial support from their family when they were a graduate student and $93(86.1 \%)$ stated that they did not.

Chi Square analysis found that participant receipt of financial support from their family as a graduate student and generational status were independent for the present study.

Table 4.13. Receipt of financial support from family as a graduate student.

\begin{tabular}{|c|c|c|c|c|}
\hline \multirow{2}{*}{$\begin{array}{c}\text { Did you receive financial support } \\
\text { from your family while you were } \\
\text { a graduate student? }\end{array}$} & & \multicolumn{2}{|c|}{ Generational status } & \multirow[b]{2}{*}{ Total } \\
\hline & & $\begin{array}{c}\text { first- } \\
\text { generation }\end{array}$ & $\begin{array}{l}\text { non-first- } \\
\text { generation }\end{array}$ & \\
\hline Yes & $\begin{array}{l}\text { Count } \\
\% \text { within } \\
\text { column }\end{array}$ & $\begin{array}{r}10 \\
9.3 \%\end{array}$ & $\begin{array}{r}15 \\
13.9 \%\end{array}$ & 25 \\
\hline No & $\begin{array}{l}\text { Count } \\
\% \text { within } \\
\text { column }\end{array}$ & $\begin{array}{r}97 \\
90.7 \%\end{array}$ & $\begin{array}{r}93 \\
86.1 \%\end{array}$ & $\begin{array}{r}190 \\
88.4 \%\end{array}$ \\
\hline Total & $\begin{array}{l}\text { Count } \\
\% \text { within } \\
\text { column }\end{array}$ & $\begin{array}{r}107 \\
100.0 \%\end{array}$ & $\begin{array}{r}108 \\
100.0 \%\end{array}$ & $\begin{array}{r}215 \\
100.0 \%\end{array}$ \\
\hline
\end{tabular}

$\left(\chi^{2}=1.08, d f=1, p<0.3\right)$ 
Student motivators. The third section of the survey focused on participant's motivation for pursuing higher education.

Table 4.14 presents the participants' responses to the question of whether they are working in an education related field. Of the 107 first-generation respondents to this prompt, $98(91.6 \%)$ stated that they were working in an education related field and 9 $(8.4 \%)$ stated that they were not.

Of the 109 non-first-generation respondents to this prompt, $106(97.2 \%)$ stated that they were working in an education related field and $3(2.8 \%)$ stated that they were not.

Chi Square analysis found that participant working in an education related field and generational status were independent for the present study. 
Table 4.14. Participants working in an education related field.

\begin{tabular}{|c|c|c|c|c|}
\hline \multirow[b]{2}{*}{$\begin{array}{l}\text { Are you currently working in an } \\
\text { education related field? }\end{array}$} & & \multicolumn{2}{|c|}{ Generational status } & \multirow[b]{2}{*}{ Total } \\
\hline & & $\begin{array}{c}\text { first- } \\
\text { generation }\end{array}$ & $\begin{array}{l}\text { non-first- } \\
\text { generation }\end{array}$ & \\
\hline $\mathrm{Ye}$ & $\begin{array}{l}\text { Count } \\
\% \text { within } \\
\text { column }\end{array}$ & $\begin{array}{r}98 \\
91.6 \%\end{array}$ & $\begin{array}{r}106 \\
97.2 \%\end{array}$ & $\begin{array}{r}204 \\
94.4 \%\end{array}$ \\
\hline $\mathrm{Nc}$ & $\begin{array}{l}\text { Count } \\
\% \text { within } \\
\text { column }\end{array}$ & $\begin{array}{r}9 \\
8.4 \%\end{array}$ & $\begin{array}{r}3 \\
2.8 \%\end{array}$ & $\begin{array}{r}12 \\
5.6 \%\end{array}$ \\
\hline Total & $\begin{array}{l}\text { Count } \\
\% \text { within } \\
\text { column }\end{array}$ & $\begin{array}{r}107 \\
100.0 \%\end{array}$ & $\begin{array}{r}109 \\
100.0 \%\end{array}$ & $\begin{array}{r}216 \\
100.0 \%\end{array}$ \\
\hline
\end{tabular}

$\left(\chi^{2}=3.23, \mathrm{df}=1, \mathrm{p}<0.07\right)$

Table 4.15 presents the participants' responses to the question of whether they decided to pursue an education doctorate for career advancement (e.g., from principal to superintendent). Of the 106 first-generation respondents to this prompt, 69 (65.1\%) stated that they did decide to pursue an education doctorate for career advancement and 37 (34.9\%) stated that they did not. 
Of the 109 non-first-generation respondents to this prompt, 68 (62.4\%) stated that they did pursue and education doctorate for career advancement and $41(37.6 \%)$ stated that they did not.

Chi Square analysis found that participant use of the doctorate for career advancement and generational status were independent for the present study.

Table 4.15. Doctorate for career advancement.

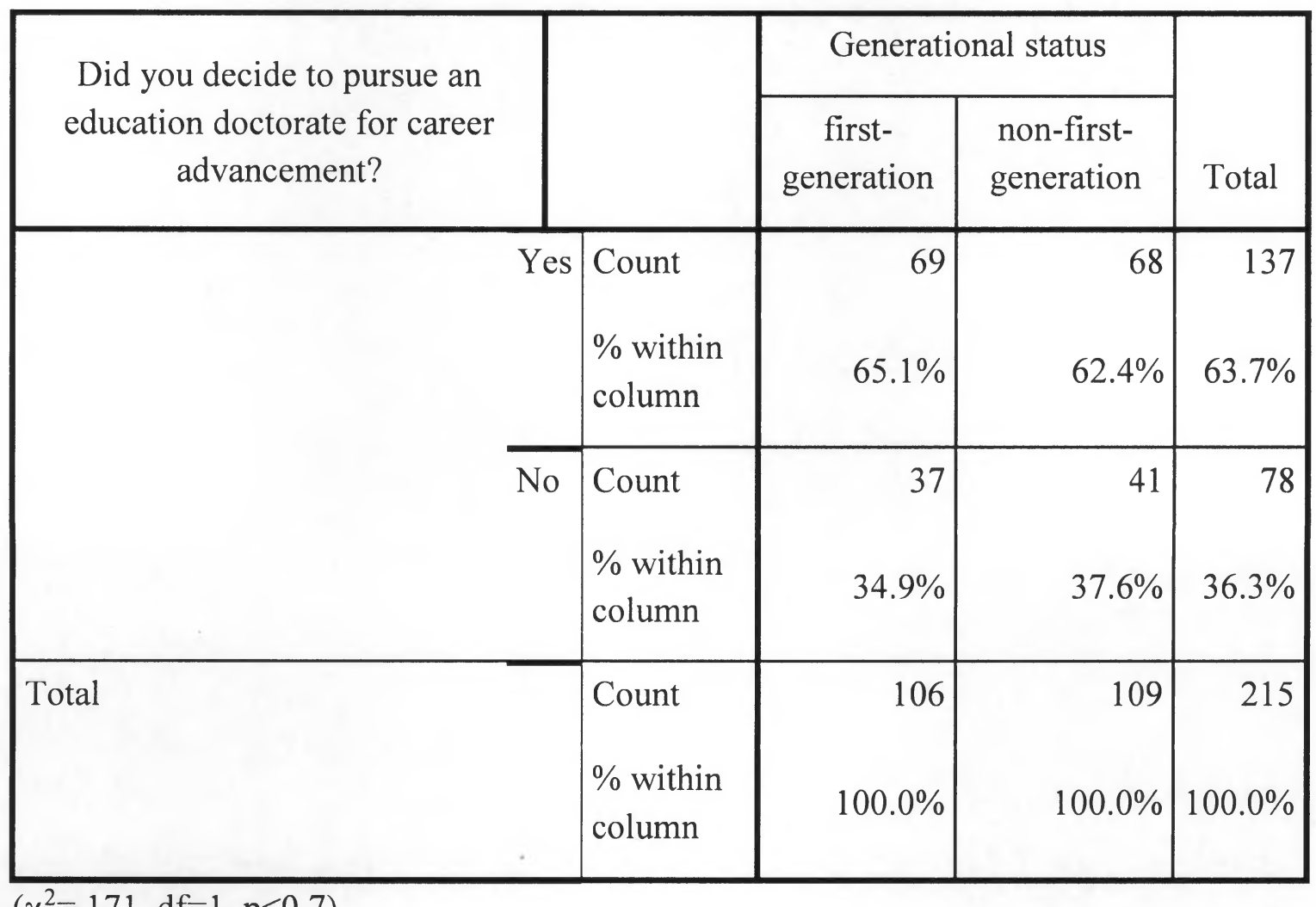

$\left(\chi^{2}=.171, \mathrm{df}=1, \mathrm{p}<0.7\right)$ 
Institutional resources. The fourth section of the survey focused on the institutional resources participants used during their educational journey.

Table 4.16 presents the participants' responses to the question of whether they lived on campus as an undergraduate student. Of the 107 first-generation respondents to this prompt, $37(34.6 \%)$ stated that they did live on campus as undergraduate students and $70(65.4 \%)$ stated that they did not.

Of the 109 non-first-generation respondents to this prompt, 56 (51.4\%) stated that they lived on campus as undergraduate students and $53(48.6 \%)$ stated that they did not.

Chi Square analysis found that participant living on campus as undergraduates and generational status were dependent for the present study. 
Table 4.16. Lived on campus as an undergraduate.

\begin{tabular}{|c|c|c|c|c|}
\hline \multirow{2}{*}{$\begin{array}{l}\text { Did you live on campus when you } \\
\text { were an undergraduate student? }\end{array}$} & & \multicolumn{2}{|c|}{ Generational status } & \multirow[b]{2}{*}{ Total } \\
\hline & & $\begin{array}{c}\text { first- } \\
\text { generation }\end{array}$ & $\begin{array}{l}\text { non-first- } \\
\text { generation }\end{array}$ & \\
\hline $\mathrm{Ye}$ & $\begin{array}{l}\text { Count } \\
\% \text { within } \\
\text { column }\end{array}$ & $\begin{array}{r}37 \\
34.6 \%\end{array}$ & $\begin{array}{r}56 \\
51.4 \%\end{array}$ & $\begin{array}{r}93 \\
43.1 \%\end{array}$ \\
\hline N & $\begin{array}{l}\text { Count } \\
\% \text { within } \\
\text { column }\end{array}$ & $\begin{array}{r}70 \\
65.4 \%\end{array}$ & $\begin{array}{r}53 \\
48.6 \%\end{array}$ & $\begin{array}{r}123 \\
56.9 \%\end{array}$ \\
\hline Total & $\begin{array}{l}\text { Count } \\
\% \text { within } \\
\text { column }\end{array}$ & $\begin{array}{r}107 \\
100.0 \%\end{array}$ & $\begin{array}{r}109 \\
100.0 \%\end{array}$ & $\begin{array}{r}216 \\
100.0 \%\end{array}$ \\
\hline
\end{tabular}

$\left(\chi^{2}=6.21, \mathrm{df}=1, \mathrm{p}<0.05\right)$

Table 4.17 presents the participant response to the question of whether they received financial aid as undergraduate students. Of the 107 first-generation respondents to this prompt, $81(75.7 \%)$ stated that they did receive financial aid as undergraduate students and $26(24.3 \%)$ stated that they did not.

Of the 109 non-first-generation respondents to this prompt, 73 (67\%) stated that did receive financial aid as undergraduate students and $36(33 \%)$ stated that they did not.

Chi Square analysis found that participant receipt of financial aid as an undergraduate and generational status were independent for the present study. 
Table 4.17. Received financial aid as an undergraduate.

\begin{tabular}{|c|c|c|c|c|}
\hline \multirow[b]{2}{*}{$\begin{array}{c}\text { Did you receive financial aid } \\
\text { during your undergraduate studies? }\end{array}$} & & \multicolumn{2}{|c|}{ Generational status } & \multirow[b]{2}{*}{ Total } \\
\hline & & $\begin{array}{c}\text { first- } \\
\text { generation }\end{array}$ & $\begin{array}{l}\text { non-first- } \\
\text { generation }\end{array}$ & \\
\hline Yes & $\begin{array}{l}\text { Count } \\
\% \text { within } \\
\text { column }\end{array}$ & $\begin{array}{r}81 \\
75.7 \%\end{array}$ & $\begin{array}{r}73 \\
67.0 \%\end{array}$ & $\begin{array}{r}154 \\
71.3 \%\end{array}$ \\
\hline No & $\begin{array}{l}\text { Count } \\
\% \text { within } \\
\text { column }\end{array}$ & $\begin{array}{r}26 \\
24.3 \%\end{array}$ & $\begin{array}{r}36 \\
33.0 \%\end{array}$ & $\begin{array}{r}62 \\
28.7 \%\end{array}$ \\
\hline Total & $\begin{array}{l}\text { Count } \\
\% \text { within } \\
\text { column }\end{array}$ & $\begin{array}{r}107 \\
100.0 \%\end{array}$ & $\begin{array}{r}109 \\
100.0 \%\end{array}$ & $\begin{array}{r}216 \\
100.0 \%\end{array}$ \\
\hline
\end{tabular}

$\left(\chi^{2}=2.01, \mathrm{df}=1, \mathrm{p}<0.2\right)$

Table 4.18 presents the participants' responses to the question of whether they received financial aid during their graduate studies. Of the 107 first-generation respondents to this prompt, 70 (65.4\%) stated that they did receive financial aid during their graduate studies and 37(34.6\%) stated that they did not.

Of the 109 non-first-generation respondents to this prompt, 71 (65.1\%) stated that they did receive financial aid during their graduate studies and $38(34.9 \%)$ stated that they did not. 
Chi Square analysis found that participant receipt of financial aid as a graduate student and generational status were independent for the present study.

Table 4.18. Received financial aid as a graduate student.

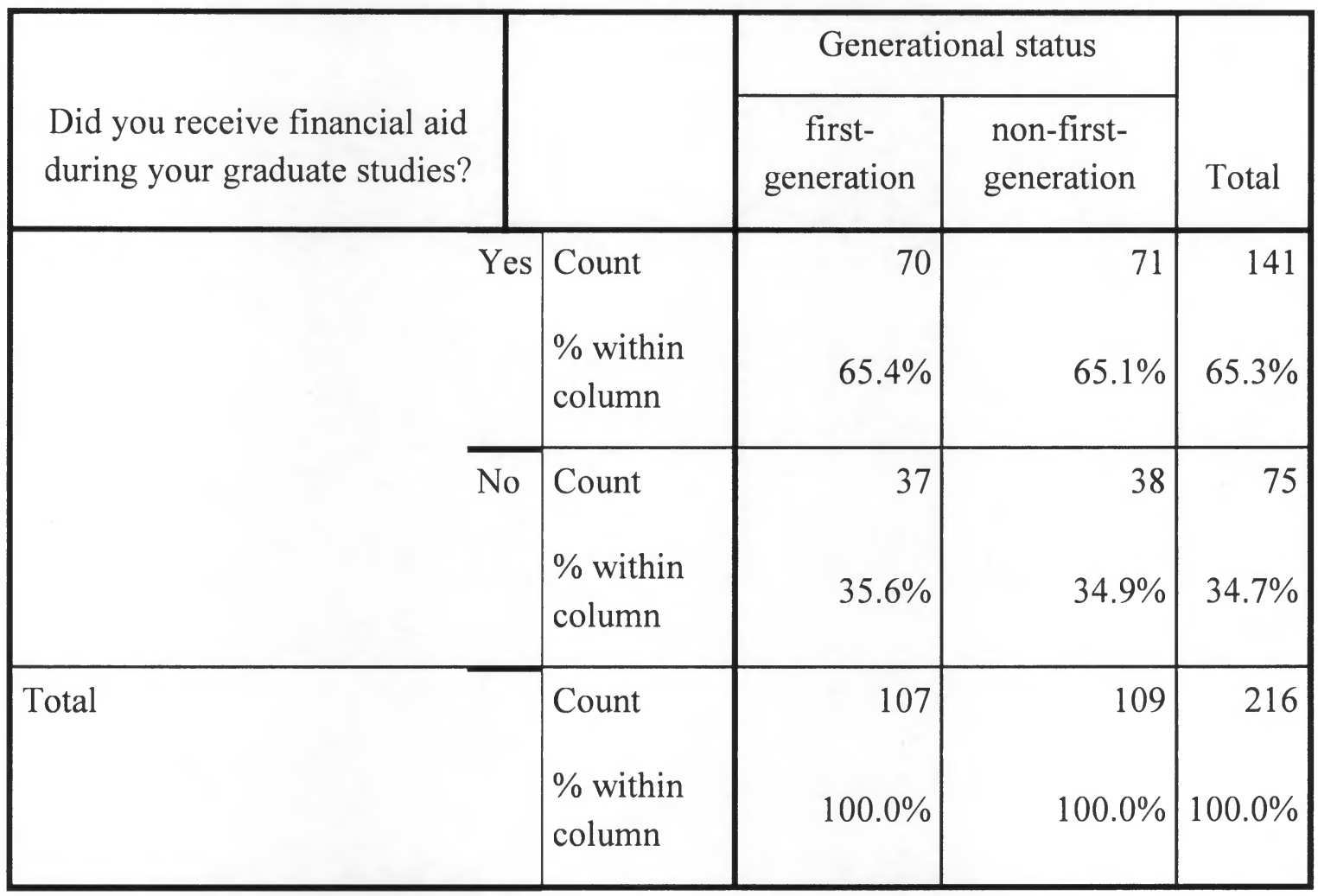

$\left(\chi^{2}=.002, \mathrm{df}=1, \mathrm{p}<1\right)$ 
Educational barriers. The fifth section of the survey focused on the barriers faced by participants during their education journey.

Table 4.19 presents the participants' responses to the question of whether they stopped-out as an undergraduate student. Stop-out refers to taking a semester or more off from school. Of the 107 first-generation respondents to this prompt, 28 (26.2\%) stated that they had stopped out during their undergraduate studies and $79(73.8 \%)$ stated that they did not.

Of the 109 non-first-generation respondents to this prompt, 28 (25.7\%) stated that they stopped-out during their undergraduate studies and $81(74.3 \%)$ stated that they had not.

Chi Square analysis found that participant stopping out as an undergraduate and generational status were independent for the present study. 
Table 4.19. Stopped out as an undergraduate.

\begin{tabular}{|c|c|c|c|c|}
\hline \multirow{2}{*}{$\begin{array}{l}\text { Did you stop-out from school as an } \\
\text { undergraduate student? Stop-out refers } \\
\text { to taking a semester or more off from } \\
\text { school. }\end{array}$} & & \multicolumn{2}{|c|}{ Generational status } & \multirow[b]{2}{*}{ Total } \\
\hline & & $\begin{array}{c}\text { first- } \\
\text { generation }\end{array}$ & $\begin{array}{l}\text { non-first- } \\
\text { generation }\end{array}$ & \\
\hline Yes & $\begin{array}{l}\text { Count } \\
\% \text { within } \\
\text { column }\end{array}$ & 28 & $\begin{array}{r}28 \\
25.7 \%\end{array}$ & $\begin{array}{r}56 \\
25.9 \%\end{array}$ \\
\hline No & $\begin{array}{l}\text { Count } \\
\% \text { within } \\
\text { column }\end{array}$ & $73.8 \%$ & $\begin{array}{r}81 \\
74.3 \%\end{array}$ & $\begin{array}{r}160 \\
74.1 \%\end{array}$ \\
\hline Total & $\begin{array}{l}\text { Count } \\
\% \text { within } \\
\text { column }\end{array}$ & $\begin{array}{r}107 \\
100.0 \%\end{array}$ & $\begin{array}{r}109 \\
100.0 \%\end{array}$ & $\begin{array}{r}216 \\
100.0 \%\end{array}$ \\
\hline
\end{tabular}

$\left(\chi^{2}=.01, \mathrm{df}=1, \mathrm{p}<1\right)$

Request for interview. The sixth section of the survey focused on requests for volunteer participation and asked:

1. Are you interested in participating in a follow-up interview about your experience as a doctoral student?

2. Are you interested in being entered into a drawing to win one (1) of four (4) $\$ 25$ gift cards?

As these questions were used to determine interview participation, no cross tabulation was developed. 


\section{Analysis of Phase 2: The Semi-Structured Interview Responses}

Twelve respondents were selected from the 229 responses and asked to participate in a semi-structured follow-up interview. This population included:

1. Current or former education doctoral students from the CSU system.

2. Representatives of three regions defined by the CSU system (i.e., Northern, Central, Southern).

3. Representation from each of the ethnic and gender groups identified in Phase 1.

The population consisted of nine first-generation students and three non-firstgeneration students.

The coding of the raw data produced a memo-code in which the following labels were developed:

1. Educational expectations.

2. The educational journey.

3. Social separations.

4. Enhanced matriculation programs. 
Educational expectations. Educational expectations refer to the ideas, notions and supports about education that influenced the students' academic experience. These expectations come from two primary sources:

1. The family.

2. The community.

The family. The data analysis revealed that educational expectations were relevant for first-generation students during their educational journey. The lack of educational expectations included first-generation students being persuaded into looking for work instead of pursuing higher education. First-generation students stated that while there may have been conversations about higher education with their family and community members, the educational expectation changed as they neared graduation from high school. For example, when asked about her parent's expectations about higher education, Jocelyn B. stated:

We were told to go to school... first it was, go ahead and go to college... when we were young. Then... as we got older it was more like, make a livable wage. School... is a luxury, and you just need to work.

Other first-generation students expressed similar scenarios, for example, Lillian G. stated:

My mother is a very good mother, great mother actually, but she's (a) blue-collar worker, she didn't pursue college so for her it was just that you 
just get a good job whatever that good job may be. Working for the government, working at a factory...that was what she...encouraged. It was just that, by the time you graduate high school, you have to be pursuing a good job, but it wasn't that after you get out of high school, you better be pursuing college.

For non-first-generation students, even in situations where they stated they were not good students, the parental expectation was still clear that the student would attend college. For example, Kahlil P. stated:

College-going culture was an expectation because we saw it in our parents and uncles and aunts, and my grandfather before he passed and I was still going to junior college was quite explicit like, "Grandson, whatever you do with life get an education." The expectation was that we were going to go to college, and that was explicit...I wasn't ready, I wasn't mature enough, I didn't even follow-up after I got the acceptance letter... and my dad told me quite explicitly when I graduated from high school he said, because I wasn't ready to get a job or be on my own he said, "Well, from this point on you can live here as long as you're in school and working."

The community. The data analysis revealed that community expectations about higher education influenced first-generation students' decisions to pursue higher education. The community included cultural, gender, extended familial, and peer 
expectations. First-generation students stated that there were college educated relatives or close family friends who encouraged their thinking about higher education. This encouragement played an integral role in their decision to pursue higher education and came in the forms of a step-parent encouraging the idea of education, parents wanting their children to do something different than they themselves did, or modeling from a person outside of the immediate family. For example, Antonio C. stated:

In my household, I grew up with a single mom for a large part of my life. My mom got remarried... My step father was one that believed in hard work but he really put something in my head, as well as my brothers, that he wanted us to be what's called pencil pushers. He was in construction and so he always took us out to work with him when we were younger and he made sure that we understood what hard work was, you know working out in the sun, working on hot roofs.

In another example, Morgan Q. stated:

It was different between my parents... my father had a sixth-grade education and although he never said it, I always got the sense that if I got a high school education, that would have been more than what he had and he would be good with that. My mom had a high school education... her younger brother...is a physician. So, she always wanted me to be a physician like him. 
There were also cultural expectations that impacted the educational expectations. For example, May Yang L. stated,

Historically it's (higher education) not common. Exposure to education in general, is quite new for the Hmong people. But in terms of women pursuing higher education and the United States in recent times, there has been a larger number of Hmong women pursuing higher education compared to the men so there's more of a concern towards how do we get the male students to access college and then graduate and have the same opportunity.

In terms of cultural expectation and traditional gender roles, Terri V. K. stated that her parents entertained the idea of college for her, but it would have been different if she had brothers:

If I grew up in a household with both brothers and sisters, the expectation would be different. I think the expectation would be that I would be playing the traditional role and get married and have kids and take care of my husband. I mean, to some extent, that still exists. In the context of my household, because we were all girls and the idea that, at some level... my father was very open to us pursuing more. I think it's that underlying sense of being first-generation that they're... and being... coming from an immigrant, third world country, the expectation of you do that and you 
still get married, have kids and take care of your husband and your family. Actually, it felt like it was an extra layer of expectation in addition to what was normally expected in my culture.

The Educational Journey. Educational journey refers to student experiences on their path toward the doctorate. There were two primary influences for first-generation students during their educational journey:

1. Institutional supports.

2. Extra-curricular activities.

Institutional supports. The data analysis revealed that institutional supports were relevant for first-generation students during their educational journey and informed their academic success. First-generation students were less likely than their non-firstgeneration peers to utilize institutional supports designed to enhance their success. Many of them stated that through athletics and club organizations they were able gain the knowledge needed to think about and pursue higher education.

This was explained by Lillian G. who stated when asked about involvement with institutional supports:

I was one of those students that was a commuter student, and I went to school and went home, so I didn't take advantage of any of those programs, nor do I feel like counselors or advisers made me aware of them. 
When asked about her use of institutional supports, Ellis D. stated:

I did not participate in anything. The one thing I did do my freshman year that was helpful was a freshman seminar. But I was an EOP eligible student but I didn't quite realize that and I didn't participate. I don't know if I would've. But yeah, so really the freshman seminar was the only thing. I did struggle with feeling out of place and feeling my value in merit versus some of my colleagues or my peers rather, because of my background. But I didn't really seek out any true networks for that or communities.

In response to questions about the role of extracurricular activities, Lillian G. stated:

I was always an athlete, basketball player, and I studied theater in high school. I do think that the extracurricular (activities) was something that I was inherently good at, so it did make me want to stay in school, yes. And it helped me like school even more. It was confidence, it was a sense of belonging, and mattering, that was the piece for me that made me really feel a connection, more to school. 
When asked about her involvement in extracurricular activities, Ellis D. added:

I should say I did end up going to San Diego State and part of the reason I ended up going there was because I had gone to cheer camp. I was a cheerleader. I had gone to cheer camp the summer before my senior year and we did that at San Diego State. We stayed in the dorm and that helped me decide to go to San Diego State. I did a lot of sports in high school, including cheerleading and was a member of the student government. In college, I was in a sorority and did most of my leadership at the university within the Greek system...it (extracurricular activities) kept me engaged and having focus and doing the right types of activities. Particularly in the high school community I grew up in, there were plenty of things to get in trouble doing and so that kept me out of trouble.

The experiences of non-first-generation students showed involvement with institutional supports designed to enhance student success differed from that of their firstgeneration peers. For example, when asked about his involvement in institutional supports Kahlil P. stated:

The most supportive program was the transfer office at UC Berkeley when I transferred as a sophomore, that was extremely helpful for me because they had a transfer class. You had a home base for navigating the large university system and making sense of all the requirements, and they had 
programs that supported and facilitated work. I had some-- I made some money through this office, they would hire me to--I would do workshops. (I've) always been a talker so I would do time management workshops, I would do a series of workshops for other students sometimes I'd have one or two people in the workshop but I got paid for that. I got a little money from that but more than that, I was able to meet with the coordinators there and they were really supportive emotionally as well as just listening and being supportive of our journey at the university.

There were also examples of non-first-generation students stating that while they were familiar with institutional supports, they did not utilize them. For example, when asked about his use of institutional supports, Jay A. stated:

Nothing that I took advantage of. I knew they were available because of being an RA (resident advisor). I became an RA, like I said, within three months of transferring... I knew they were there because RA trainings will get you familiar with them and all the programs and things, but not introduced to like it was for me. Even advising, I just found one of those regular advising officers for general advisement, I didn't even know that my major had specific advisers for it.

Social separations. Social separation refers to emotional and physical separation from one's surroundings. There were two sub-variables within social separation: 
1. The family.

2. The community.

The family. The data analysis revealed that social separation from family members was relevant for first-generation students during their educational journey and informed their academic success. Social separation refers to the feelings of exclusion and otherness that grew between first-generation students and their family members.

In response to questions about social separation, first-generation students stated that they felt isolated as they progressed through academia. For example, when asked about emotions directed toward him from his family as he progressed academically, Antonio C. stated:

There was a feeling of, I would've constantly get, "You think you're better than us now? You think you're all high and mighty now? You're a college boy." I'd always get that. I get that from all my cousins. I get that from other family members. My mom and dad were definitely proud of me but from friends and family, it was more of the: "What, you think you're better than us." That's what I would constantly get. It wasn't the, "Oh, congratulations. Oh, man, we're so proud of you." It was like, "Oh, you think you're better than us now." That was the separation that I was starting to feel. 
Social separation was exacerbated as first-generation students progressed through advanced studies. First-generations students noted that in some cases they were mocked for being academically successful. For example, when asked about social separation after receiving her master's degree, Joscelyn B. stated:

But at the end (of my master's degree program), I could see just a slight... little separation that occurred that was like different from my twoyear degree, it got bigger, then for my bachelor's degree was a little bit bigger, just a little bit. Because now in my mind...was this critical awareness of the world around me... I thought a lot more and they didn't, until it became... "Why do you always have to question everything?" ... I wasn't being adversarial but I would question. 
Mocking was also experienced by first-generation students. For example, Taylor $R$. who when responding to the question of whether she felt separation from her family as she progressed through graduate school, stated:

Definitely (by) my family...I think that they viewed me differently. I was the first person in my family to graduate from college, in my immediate family. I had a second cousin, who graduated with a bachelor's, but I don't know if my family knew anybody, even knew anybody with a master's degree. I remember once when I was in graduate school, my grandpa saying one time, when I aspired for grad school, and he said, "Okay, we get it. Enough." Like you have shown yourself that's fine, you don't have to keep going. I never really knew what to take up. I think if I had brought it up with him, he would have been embarrassed. But I never knew what to think of that. What does he mean? Does he think I'm trying to show off? For that I'm doing it for me. I'm not doing it for you all, but I was getting introduced as, "This is my daughter. She's done her master's." "This is my granddaughter, she went to States for her master's." There was very much I felt there was a separation, especially between me and my siblings by others. I would hear people say, "They don't understand, because you got a different view because you went to college. You're a master." I definitely felt that. 
The community. The data revealed that social separation from community was relevant for first-generation students during their educational journey and informed their academic success. Social separation from community refers to the feelings of exclusion and otherness that grew between first-generation students and their community. For example, Ellis D. stated:

I would say there were and are people who don't relate or give me an odd amount of praise and recognition for the accomplishment and I prefer to kind of be understated a little bit so I was surprised completing the program how much weight it carries. I take pride in my accomplishment but people did respond in ways that I was sensitized about.

If I think about my community I grew up in, my brother has his GED now. His wife didn't finish high school and sometimes at times with his wife's family and none of them finished high school or haven't any advanced or college experience and so when he introduced me, "This is my sister, the doctor," I actually feel like I have this air that I carry. I can't just be a regular person because I'm a doctor...So that's the hard thing sometimes and I think my friends, my community that I know from college and other places I think they just take pride in that and so that's nice....I think what it is that people just see this as a really major accomplishment, and it is I don't discount that, but people for me anyways have a perfect specifications that go along with it that I think are different than I feel. 
One other example which is kind of funny, a family friend of my husband's, I like missed at a word or something and she's like, "You're a doctor you can't have that grammar or you can't not know how to spell." I'm just, okay, thank you I guess. What does that mean? So I think it's just having that title people then assume you're something else and I'm just a normal person and I think that's what I struggle with in the communities where people don't necessarily have that education that I become different and they're not quite sure what to do with me...I'd rather just be like everybody else....

Social separation was different for non-first-generation students. While firstgeneration students experienced feelings of social isolation, their non-first-generation peers were celebrated for their academic accomplishments. For example, when asked whether he felt separated from his family, peers, or community, Jay A. stated:

No, I don't feel like there was a difference, I thought there was probably a sense of accomplishment. Obviously, my older sister that encouraged me to go was super proud. Family came, celebrated.

This difference was also highlighted by Kahlil P. who in response to the question of whether he felt separated from his family when he received his doctorate answered:

No. In fact, the opposite happened especially when I graduated, up to that point it was more or less a personal endeavor. There was something in my 
family supported me in. As soon as I graduated (with my Ed.D.) it became a community accomplishment. Aunties that I haven't seen since I was 10 or 11-- everybody was so proud in a way that it exceeded the accomplishment of one person but it was more of an affirmation of the power and brilliance and beauty of the black community in Oakland.

Enhanced matriculation programs. Enhanced matriculation programs refer to recommendations offered by the study participants on the ways institutions can better support academic success. There were two suggestions from first-generation students on how the institution could better serve future first-generation students:

1. Mandatory engagement.

2. Networking.

Mandatory engagement. First-generation students expressed that they did not seek student support programs and suggested that when participation was optional they would likely choose not to participate. For example, when asked about ways in which the institution improved her experience, Terri V. K. stated:

I think what they did was they built a program that was cohorted. From beginning to end, there was a level of practicum embedded in that structure. I think it was set up for me who you know was first in my family to get a Master's degree to be able to be successful, because it created a network for me that I could click into automatically, I didn't have 
to seek them out. It provides me with work experience which I knew like I could excel in and that was the space where I always did well. The faculty knew us because we were a cohorted folk and so that meeting and getting to know faculty was not as challenging. I think they built a structure that was very helpful.

The value of the cohort model was also seen as a valuable tool for others. For example, Ellis D. stated:

Some mandatory advising because I did take the good advantage of advising, academic advising. More orientation around faculty engagement, how you connect with a faculty member, how you utilize in their office hours, those kinds of things. Opportunities to engage in high-impact practices.

The idea that the institution should make student support programs mandatory was shared by non-first-generation participants as well. Jay A. reflected on the benefits of the cohort model:

I think a theme would always come back to caring, taking care. They could demonstrate they care through engagement, through outreach, through communication, through just even touching base with students. The Master's program is where I got married, and I had figured it out, and figured it out on my own, but I don't think anybody, even in a doc 
program... which is cohort-based - but knowing you're part of something bigger and that you're part of a community that is there to help you achieve your goals.

Even (having) somebody to sit down and listen to your goals, and ensure you're on the right track and not overlooking the roadblocks or speed bumps... The work schools can do to help individuals articulate where they want to be, reflect on where they want to be, and then ensure that the institution is not putting roadblocks in the way.

Networking. Networking refers to the conscious efforts of developing professional contacts that further career opportunities or aspirations. For all students in this study the concept of networking as a tool to advance career did not become clear until they entered graduate school. This finding is exampled by Lillian G., who stated that for her networking:

... started happening in grad school. In my Master's program, I started realizing because I was in a cohort with other executives. And I started to really understand what they were doing, and why they were doing it. I was already in a corporate job, but it made me think about why I was pursuing my master's degree, why other people were pursuing theirs, I even helped students, current students get jobs in different -- like Yahoo, because one of my former grad programs members was a senior officer. 
Others stated that networking was forcefully introduced to them. For example, in response to whether she understood the value of networking, May Yang L. stated:

Yes, at a much later point in my educational journey. After, I finished my master's degree then I figured out the importance of networking. But before then I was always wondering to myself, "you know, why is this person trying to get me to meet with that person or why does my dad want me to talk to that person or you know it's like leave me alone." But after I finished my master's Degree. I recognized the importance of networking because I graduated in 2004. So I went back to get my master's degree I believe in 2009 and then I finished in 2012. Well anyway during that whole time, with the economic recession and all that and problems with realty, and people not finding employment opportunities. Then I recognized how important it is to really know people, that can pull you to different kind of career opportunities.

Other interviewees stated that although they had been networking their entire lives, they did not realize the importance of formal networking until graduate school. For example, Morgan Q. stated:

...it wasn't so much from my educational it was from my work. My second job out of Grad school was working for a consulting firm. I was with them for only a year and a half, but probably there were two catalysts 
for my understanding of networking... they drilled into our heads that the way that you're going to succeed and ultimately become a partner in the firm was, by being a rainmaker, bringing in new business and you can only do that by networking. I learned the value of it then...

There were examples of informal networking within the family while growing up. Morgan Q. stated:

...I learned the value of networking from my grandfather... My grandfather was really influential in setting my values and so forth. He was a community leader in Chinatown. I recognized already that when I was five years old, eight years old walking with my grandfather in Chinatown, everybody seemed to know him and respect him. Even though I didn't know what he did... I clearly saw that people respected him and he had a wide network.

Non-first-generation students suggested that they too did not recognize the value of networking until after completing their undergraduate studies. For example, Kahlil P. stated:

Now that I have proven to myself that I can work hard, on a full load what they were throwing people out of Berkeley for-- I've transferred as a sophomore, it was like, "oh, okay this is not rocket science. I saw right away that the people that I met at UC Berkeley had access, had 
connections. They weren't necessarily really smart, but it was the fact they were in Berkeley and they knew these people and they had certain information that made a lot of people have more opportunities for success. I realize right away okay it's not just what you know, it's literally who you know. By the time I was in the master's program it was crystal clear because we were all working professionals, working in the counties, working in the nonprofits and so.

\section{Chapter 5}

\section{CONCLUSIONS}

This chapter is presented in four sections:

1. Study summary.

2. Conclusions of the study.

3. Study implications

4. Limitations of the study.

5. Recommendations for further study.

\section{Study summary}

The purpose of this study is to: 
Limitations of the study. This study had two limitations:

1. Sample size.

2. The location of the institutions.

Sample size. While the goal of this study was to understand the characteristics, motivators and barriers for current and former students in the CSU Ed.D. programs, the respondent rate of $25.6 \%$ did not allow for the findings to be generalized.

Further, although the researcher made every attempt to include every diverse voice that exists in the CSU Ed.D., this study lacked equal representation from all groups, as well as, equal representation from each group from each of the three geographic regions within California. For example, the experiences of a first-generation Latino or Hispanic student in Fresno, with its relatively high concentration of Latino or Hispanic students, may be different than if that same student attended school in Sonoma with a large White population. This difference in location could inform both the experiences of and success in these different environments.

Location of institution. California has historically been receptive to diversity, which complicates the generalizability of this study's findings. Had this study been conducted in a more racially homogenous region, a more exclusive institutional setting, or a state with less of a focus to social justice, the findings may have been different. Firstgeneration students who pursued the Ed.D. in the CSU system may have done so because of the supports that is offered there. This support could have come from the CSU focus 
on teaching, or its efforts to maintain student support programs. Further, the CSU system, with its focus on developing teachers and increasing focus on social justice may have attracted students who were more likely to benefit from the structure of the programs, which could have skewed the ratio of first-generation students to their non-firstgeneration peers.

\section{Recommendations for further study}

This study indicates five areas of further study:

1. Examine the differences in reaction from family and community to firstgeneration students pursing their master's degree.

2. Revisit the ways in which student support programs engage students.

3. Examine the relationship between the receipt of negative advice from high school guidance counselors and likelihood of first-generation students using student support programs in college.

4. Examine how to increase the awareness of and importance for networking to students from disadvantaged backgrounds.

5. Investigate a way to identify and support first-generation students beyond the bachelor's degree.

\section{Examine the differences in reaction from family and community to first-} generation students pursing their master's degree. The findings from this study suggest that there a distinct difference between the family and community response to 
first-generation students during their master degree studies. It was unclear whether family and community members understood the separation between master's and bachelor's degrees. Future research can examine why family and community response to firstgeneration students at the master's level differed from both the bachelor's degree and doctorate degree.

Revisit the ways in which student support programs engage students. The findings from this research are consistent with previous research in that first-generation students are not likely to live on campus during their undergraduate years. The findings from this research also suggest that all students in this study did not understand the importance of formal networking until graduate school. These two findings provide an opportunity for existing student support programs to develop mechanisms that would bridge the gap for students from disadvantaged backgrounds. If first-generation students are not living on campus, partnering with the counseling office on campus to identify incoming first-generation students could offer a means to intentionally offer support to this growing, yet difficult to recognize student population.

\section{Examine the relationship between the receipt of negative advice from high} school guidance counselors and likelihood of first-generation students using student support programs in college. The findings from this study suggest that high school guidance counselors would not inform first-generation students about the process of entering higher education, instead, they would encourage them to pursue trades. Future research could examine the relationship between this early lack of confidence by 
guidance counselors and the decreased likelihood of first-generation students desire to utilize student support services in higher education.

Examine how to increase the awareness of and importance for networking to students from disadvantaged backgrounds. Participants in this study found ways to successfully overcome their academic barriers and remain resilient on their education journey to the Ed.D. However, it is unclear what percentage of students may have dropped out due to lack of knowledge of available campus resources. Future research could examine promising practices that ensure that a higher percentage of students from disadvantaged backgrounds take advantage of these student support services.

\section{Including a way to identify and support first-generation students beyond the} bachelor's degree. Currently the CSU does not collect generational information for its doctoral students. As one of the goals of the CSU Ed.D. program was to diversify the pool of doctoral trained educational leaders in California, it is imperative that generational status be included in the way people understand diversity. By including data gathering of generational status for doctoral students at the graduate level, the CSU will be able to capture a more accurate picture of how well they are achieving their goals. Further, as first-generation students represent a large proportion of students entering higher education in the state, understanding their educational journey toward the 
doctorate can provide an understanding of how to ensure more first-generation students are academically successful.

\section{Concluding Statement}

This study documented the characteristics, motivators and barriers for current and former first-generation and non-first-generation students in the CSU Ed.D. programs. The findings suggest that first-generation students are at a disadvantage with both knowing about and taking advantage of student support programs as they currently exist. While higher education has evolved from its singular focus, the inclusion of diverse voice in program development and structuring has not. With higher education becoming increasingly necessary for social mobility, ensuring the success of a wider array of students is of the utmost importance. As institutions seek ways to understand the student experience and to create programs to mitigate potential barriers, it is important that

diverse voice be heard. The CSU Ed.D. programs, as they were initially designed are providing the supports necessary to allow a wider range of the population to gain the critical thinking skills gained through doctoral training. As the CSU Ed.D. program focuses on social justice, their graduates are more likely to be attuned to the needs of the surrounding populace. 


\section{REFERENCES}

12.03.2003 - Clark Kerr's legacy: 1960 Master Plan transformed higher education. (n.d.). Retrieved October 31, 2016, from http://www.berkeley.edu/news/media/releases/2003/12/03_master.shtml 2016 Facts About the CSU | CSU. (n.d.). Retrieved November 1, 2016, from http://www.calstate.edu/csufacts/2016Facts/

Alessandria, K. P., \& Nelson, E. S. (2005). Identity Development and Self-Esteem of First-Generation American College Students: An Exploratory Study. Journal of College Student Development, 46(1), 3-12. https://doi.org/10.1353/csd.2005.0001

Almquist, E. M., Angrist, S. S., \& American Sociological Association. (1970). Role model influences on college women's career aspirations: a paper prepared for presentation at the 65th annual meeting of the American Sociological Association, August 31 - September 3, 1970.

Altbach, P. G., Berdahl, R. O., \& Gumport, P. J. (1999). American higher education in the twenty-first century: social, political, and economic challenges. Baltimore: Johns Hopkins University Press.

American Council on Education (Ed.). (1937). The student personnel point of view; Washington, D.C.: The American council on education].

American Council on Education, Committee on Student Personnel Work, \& Williamson, E. G. (1949). The student personnel point of view. Washington. 
A Shared Agenda: A Leadership Challenge to Improve College Access and Success. (2004). Pathways to College Network. Retrieved from http://eric.ed.gov/?id=ED514440

Astin, A. W. (1998). The changing American college student: thirty-year trends, 19661996. The Review of Higher Education: A Bulletin of the Association for the Study of Higher Education Review of Higher Education, 21(2), 115-135.

Attewell, P., Lavin, D., Domina, T., \& Levey, T. (2007). Passing the Torch: Does Higher Education for the Disadvantaged Pay Off Across the Generations?. Russell Sage Foundation.

Bandura, A. (1977). Self-efficacy: Toward a unifying theory of behavioral change. Psychological Review, 84(2), 191-215. https://doi.org/10.1037/0033295X.84.2.191

Bandura, A. (1986). The Explanatory and Predictive Scope of Self-Efficacy Theory. Journal of Social and Clinical Psychology, 4(3), 359-373. https://doi.org/10.1521/jscp.1986.4.3.359

Billson, J. M., \& Terry, M. B. (1982). In Search of the Silken Purse: Factors in Attrition among First-Generation Students. College and University, 58(1), 57-75.

Black and white racial identity: theory, research, and practice. (1990) (Vol. xviii). New York, NY, England: Greenwood Press.

Bogue, E. G., \& Aper, J. (2000). Exploring the heritage of American higher education: the evolution of philosophy and policy. Phoenix, Ariz.: Oryx Press. 
Bonilla-Silva, E. (2001). White supremacy and racism in the post-civil rights era. Boulder, Colo.: L. Rienner.

Bonner, F. A., Lewis, C. W., Bowman-Perrott, L., Hill-Jackson, V., \& James, M. (2009). Definition, Identification, Identity, and Culture: A Unique Alchemy Impacting the Success of Gifted African American Millennial Males in School. Journal for the Education of the Gifted., 33(2), 176-202.

Bourdieu, P. (1986). The forms of capital: Handbook of theory and research for the sociology of education (1st ed.). S.l.: Blackwell Publishers Ltd.

Bourdieu, P. (1987). What Makes a Social Class? On The Theoretical and Practical Existence of Groups. Berkeley Journal of Sociology, 32, 1-17.

Bourdieu, P., \& Passeron, J. C. (1990). Reproduction in Education, Society and Culture. SAGE.

Bowen, W. G., \& Bok, D. C. (1998). The shape of the river: long-term consequences of considering race in college and university admissions. Princeton, N.J.: Princeton University Press.

Breen, R., \& Jonsson, J. O. (2005). Inequality of Opportunity in Comparative Perspective: Recent Research on Educational Attainment and Social Mobility. Annual Review of Sociology, 31, 223-243.

California Master Plan for Higher Education. (n.d.). Retrieved October 31, 2016, from http://www.ucop.edu/acadinit/mastplan/kerr082499.htm 
CalState Stat Report 2012-13. (n.d.). Retrieved November 1, 2016, from https://www.calstate.edu/as/stat_reports/2012-2013/feth04.htm

Chang, B., \& Au, W. (2007). You're Asian, how could you fail Math?: Unmasking the myth of the model minority., 22(2), 15-19.

Chickering, A. W., \& Gamson, Z. F. (1987). Seven Principles for Good Practice in Undergraduate Education. AAHE Bulletin. Retrieved from http://eric.ed.gov/?id=ED282491

Chow, K., \& Healey, M. (2008). Place attachment and place identity: First-year undergraduates making the transition from home to university. Journal of Environmental Psychology, 28(4), 362-372.

Choy, S. (2001). Students Whose Parents Did Not Go to College: Postsecondary Access, Persistence, and Attainment. Findings from the Condition of Education, 2001. Retrieved from http://eric.ed.gov/?id=ED460660

Coleman, J. S. (1988). Social Capital in the Creation of Human Capital. American Journal of Sociology, 94, S95-S120.

Collier, P., \& Morgan, D. L. (2008). "Is that paper really due today?": differences in firstgeneration and traditional college students' understandings of faculty expectations. Higher Education, 55(4), 425-446.

Commission, A. (2006). California State University Template for System-Level Information. State of California. Retrieved from http://www.calstate.edu/APP/EdD/documents/wasc_sub_change_proposals.pdf 
Company, M. (2009). The economic cost of the US education gap | McKinsey \& Company [http://mckinseyonsociety.com/the-economic-impact-of-theachievement-gap-in-americas-schools/]. Retrieved November 6, 2013, from http://www.mckinsey.com/insights/social_sector/the_economic_cost_of_the_us_e ducation_gap

Conley, D. T. (2008). Rethinking College Readiness. New England Journal of Higher Education, 22(5), 24-26.

Creswell, J. W., \& Plano Clark, V. L. (2011). Designing and conducting mixed methods research. Los Angeles, CA: SAGE Publications.

Cross Jr., W. E. (1995). The psychology of nigrescence: Revising the Cross model. In J. G. Ponterotto, J. M. Casas, L. A. Suzuki, \& C. M. Alexander (Eds.), Handbook of multicultural counseling (pp. 93-122). Thousand Oaks, CA, US: Sage Publications, Inc.

Dekker, P., \& Uslaner, E. M. (Eds.). (n.d.). Social capital and participation in everyday life. London: Routledge.

Dennis, J. M., Phinney, J. S., \& Chuateco, L. I. (2005). The Role of Motivation, Parental Support, and Peer Support in the Academic Success of Ethnic Minority FirstGeneration College Students. Journal of College Student Development, 46(3), $223-236$.

Does Diversity Matter in the Education Process? An Exploration of Student Interactions by Wealth, Religion, Politics, Race, Ethnicity and Immigrant Status at the 
University of California. (2008). eScholarship, University of California. Retrieved from http://www.escholarship.org/uc/item/4cv9z4wq

Engle, J., \& Tinto, V. (2008). Moving Beyond Access: College Success for Low-Income, First-Generation Students. Pell Institute for the Study of Opportunity in Higher Education. Retrieved from http://eric.ed.gov/?id=ED504448

Erickson, E. (1959). Identity and the life cycles: Selected Papers. Psychological Issues, 1, $1-171$.

Espinoza-Herold, M. (2003). Issues in Latino education: race, school culture, and the politics of academic success. Boston: Allyn and Bacon.

Ewing, K. M. (1996). The Relationship between Racial Identity Attitudes, Worldview, and African American Graduate Students' Experience of the Imposter Phenomenon. Journal of Black Psychology, 22(1), 53-66.

Gandara, P. C. (1995). Over the Ivy Walls: The Educational Mobility of Low-Income Chicanos. SUNY Press.

Gardner, S. (2007). "I Heard it through the Grapevine": Doctoral Student Socialization in Chemistry and History. Higher Education, 54(5), 723-740.

Gardner, S. K., \& Holley, K. A. (2011). "Those invisible barriers are real": The Progression of First-Generation Students Through Doctoral Education. Equity \& Excellence in Education, 44(1), 77-92. https://doi.org/10.1080/10665684.2011.529791 
Geiser, S., \& Atkinson, R. C. (2013). Beyond the Master Plan: The Case for Restructuring Baccalaureate Education in California. California Journal of Politics and Policy, 5(1). https://doi.org/10.1515/cjpp-2012-0042

Gilligan, C. (1982). IN A DIFFERENT VOICE. Harvard University Press.

Gofen, A. (2009). Family Capital: How First-Generation Higher Education Students Break the Intergenerational Cycle. Family Relations, 58(1), 104-120. https://doi.org/10.1111/j.1741-3729.2008.00538.x

Golafshani, N. (2003). Understanding Reliability and Validity in Qualitative Research. The Qualitative Report, 8(4), 597-606.

Graaf, P. M. D. (1986). The Impact of Financial and Cultural Resources on Educational Attainment in the Netherlands. Sociology of Education, 59(4), 237-246. https://doi.org/10.2307/2112350

Gullatt, Y., \& Jan, W. (2003). How do pre-colligiate academic outreach programs impact college-going among underrepresented students. Washington DC: Pathways to COllege Network Clearninghouse. Retrieved from http://citeseerx.ist.psu.edu/viewdoc/download?doi=10.1.1.483.7094\&rep=rep1\&t ype $=$ pdf

Hall, L. A., \& Burns, L. D. (2009). Identity Development and Mentoring in Doctoral Education. Harvard Educational Review, 79(1), 49-70. 
Hesse-Biber S, Livingstone S, Ramirez D, Barko E.B, \& Johnson A.L. (2010). Racial Identity and Body Image Among Black Female College Students Attending Predominately White Colleges. Sex Roles Sex Roles, 63(9-10), 697-711.

Holley, K. A., \& Gardner, S. (2012). Navigating the pipeline: How socio-cultural influences impact first-generation doctoral students. Journal of Diversity in Higher Education, 5(2), 112-121. https://doi.org/10.1037/a0026840

Hossler, D., \& Gallagher, K. S. (1987). Studying Student College Choice: A Three-Phase Model and the Implications for Policymakers. College and University, 62(3), $207-21$.

Hsiao, K. P. (1992). First-Generation Colleege Students. Eric Digest.

Hughes, R. L., \& Howard-Hamilton, M. F. (2003). Insights: emphasizing issues that affect African American women. New Directions for Student Services, 2003(104), 95-104. https://doi.org/10.1002/ss.110

Information Digest 1979. Postsecondary Education in California. (1979). Retrieved from http://eric.ed.gov/?q=ED180390\&id=ED180390

Ishitani, T. T. (2006). Studying Attrition and Degree Completion Behavior among FirstGeneration College Students in the United States. Journal of Higher Education, $77(5), 861-885$.

Ishiyama, J. T., \& Hopkins, V. M. (2003). Assessing the Impact of a Graduate School Preparation Program on First-Generation, Low-Income College Students at a 
Public Liberal Arts University. Journal of College Student Retention, 4(4), 393405.

Ivankova, N. V., Creswell, J. W., \& Stick, S. L. (2006). Using Mixed-Methods Sequential Explanatory Design: From Theory to Practice. Field Methods, 18(1), 3-20. https://doi.org/10.1177/1525822X05282260

Jones, S. R. (1997). Voices of Identity and Difference: A Qualitative Exploration of the Multiple Dimensions of Identity Development in Women College Students. Journal of College Student Development, 38(4), 376-86.

Jones, S. R., Abes, E. S., \& Magolda, M. B. B. (2013). Identity Development of College. Students: Advancing Frameworks for Multiple Dimensions of Identity (1 edition). San Francisco, Calif: Jossey-Bass.

Karabel, J., \& Astin, A. W. (1975). Social Class, Academic Ability, and College “Quality.” Social Forces, 53(3), 381-398. https://doi.org/10.1093/sf/53.3.381

Kemp, A. D. (1990). From Matriculation to Graduation: Focusing Beyond Minority Retention. Journal of Multicultural Counseling and Development, 18(3), 144149. https://doi.org/10.1002/j.2161-1912.1990.tb00444.x

Kim, D. (2004). The Effect of Financial Aid on Students' College Choice: Differences by Racial Groups. Research in Higher Education, 45(1), 43-70.

Litten, L. H. (1982). Different Strokes in the Applicant Pool: Some Refinements in a Model of Student College Choice. The Journal of Higher Education, 53(4), 383402. https://doi.org/10.2307/1981605 
Lohfink, M., \& Paulsen, M. (2005). Comparing the Determinants of Persistence for FirstGeneration and Continuing-Generation Students. Journal of College Student Development, 46(4), 409-428.

Lugg, C. A. (2003). Sissies, Faggots, Lezzies, and Dykes: Gender, Sexual Orientation, and a New Politics of Education? Educational Administration Quarterly, 39(1), 95-134. https://doi.org/10.1177/0013161X02239762

Lunceford, B. (2011). When first-generation students go to graduate school. New Directions for Teaching and Learning, 2011(127), 13-20.

Luthar, S. S., Cicchetti, D., \& Becker, B. (2000). The Construct of Resilience: A Critical Evaluation and Guidelines for Future Work. Child Development, 71(3), 543-62.

Matosantos, A., \& Reed, C. (2011, January 1). Evaluation of Education Doctorate Program Implementation at California State University. Retrieved from http://www.lao.ca.gov/reports/2011/edu/csu_educ_degree/CSU_EdD_White_Pap er_Report.pdf

McAlpine, L., \& Amundsen, C. (2011). Doctoral education: research-based strategies for doctoral students, supervisors and administrators. Dordrecht; New York: Springer.

McCarron, G. P., \& Inkelas, K. K. (2006). The Gap between Educational Aspirations and Attainment for First-Generation College Students and the Role of Parental Involvement. Journal of College Student Development, 47(5), 534-549. https://doi.org/10.1353/csd.2006.0059 
McClellan, G. S., Stringer, J., Barr, M. J., \& National Association of Student Personnel Administrators (U.S.). (2009). The handbook of student affairs administration. San Francisco, CA: Jossey-Bass.

McDonough, P. M., \& Antonio, A. L. (1996). Ethnic and Racial Differences in Selectivity of College Choice. Retrieved from http://eric.ed.gov/?id=ED394466 Merriam, S. B. (1998). Qualitative Research and Case Study Applications in Education. Revised and Expanded from "Case Study Research in Education.". Jossey-Bass Publishers, 350 Sansome St, San Francisco, CA 94104; phone: 415-433-1740; fax: 800-605-2665; World Wide Web: www.josseybass.com (\$21.95). Retrieved from http://eric.ed.gov/?id=ed415771

Miles, M. B., \& Huberman, A. M. (1994). Qualitative Data Analysis: An Expanded Sourcebook. SAGE.

Miles, M. B., Huberman, A. M., \& Saldaña, J. (2014). Qualitative data analysis: a methods sourcebook.

Museus, S. D., \& Neville, K. M. (2012). Delineating the Ways that Key Institutional Agents Provide Racial Minority Students with Access to Social Capital in College. Journal of College Student Development, 53(3), 436-452.

Nadal, K. L., Pituc, S. T., Esparrago, T., \& Johnston, M. P. (2010). Overcoming the Model Minority Myth: Experiences of Filipino American Graduate Students. Journal of College Student Development, 51(6), 694-706. 
National Research Council (U.S.), Office of Scientific Personnel, National Research Council (U.S.), Board on Human-Resource Data and Analyses, National Research Council (U.S.), Commission on Human Resources, ... National Science Foundation (U.S.). (1967). Summary report ... doctorate recipients from United States universities. Summary Report ... Doctorate Recipients from United States Universities.

National Science Foundation, \& National Center for Science and Engineering Statistics. (2015). Doctorate Recipients from U.S. Universities: 2014. National Science Foundation. Retrieved from http://swemgovdocs.blogs.wm.edu/2015/12/16/doctorate-recipients-from-u-suniversities-2014-2/

Nunez, A.-M., \& Cuccaro-Alamin, S. (1998). First-Generation Students:

Undergraduates Whose Parents Never Enrolled in Postsecondary Education. Statistical Analysis Report. Postsecondary Education Descriptive Analysis Reports.

Office of the Chancellor. (2007, August).

Office of the President, U. of C. (2014). Doctoral Persistence and Completion Rates: Fall 2000-2002 Entry Cohorts. Retrieved from http://www.ucop.edu/institutionalresearch-academic-planning/_files/uc-doctoral-completions.pdf

Ogbu, J. U. (1994). Racial stratification and education in the United States: Why inequality persists. Teachers College Record, 96(2), 264-298. 
Orbe, M. P. (2004). Negotiating multiple identities within multiple frames: an analysis of first-generation college students. Communication Education, 53(2), 131-149. https://doi.org/10.1080/03634520410001682401

Padgett, R. D., Johnson, M. P., \& Pascarella, E. T. (2012). First-Generation Undergraduate Students and the Impacts of the First Year of College: Additional Evidence. Journal of College Student Development, 53(2), 243-266.

Padilla, A. M. (2008). Social Cognition, Ethnic Identity, and Ethnic Specific Strategies for Coping with Threat due to Prejudice and Discrimination. In C. Willis-Esqueda (Ed.), Motivational Aspects of Prejudice and Racism (pp. 7-42). Springer New York. Retrieved from http://0-

link.springer.com.opac.sfsu.edu/chapter/10.1007/978-0-387-73233-6_2

Pascarella, E. T., Pierson, C. T., \& Wolniak, G. C. (2004). First-Generation College Students: Additional Evidence on College Experiences and Outcomes. Journal of Higher Education, 75(3), 249.

Pascarella, E. T., Seifert, T. A., \& Whitt, E. J. (2008). Effective instruction and college student persistence: Some new evidence. New Directions for Teaching \& Learning, 2008(115), 55-70. https://doi.org/10.1002/t1.325

Pascarella, E. T., \& Terenzini, P. T. (1979). Student-Faculty Informal Contact and College Persistence: A Further Investigation. Journal of Educational Research, 72(4), 214-18. 
Patton, M. Q. (1990). Qualitative evaluation and research methods, 2nd ed. Thousand Oaks, CA, US: Sage Publications, Inc.

Paulsen, M. B. (1990). College Choice: Understanding Student Enrollment Behavior. ASHE-ERIC Higher Education Report No. 6. ASHE-ERIC Higher Education Reports, The George Washington University, One Dupont Circle, Suite 630, Dept. RC, Washington, DC 20036-1183 (\$17.00). Retrieved from http://eric.ed.gov/?id=ED333855

Petty, T. (2014). Motivating First-Generation Students to Academic Success and College Completion. College Student Journal, 48(2), 257-264.

Piaget, J. (1976). Piaget's Theory. In B. Inhelder, H. H. Chipman, \& C. Zwingmann (Eds.), Piaget and His School (pp. 11-23). Springer Berlin Heidelberg. Retrieved from http://link.springer.com/chapter/10.1007/978-3-642-46323-5_2

Piorkowski, G. K. (1983). Survivor Guilt in the University Setting. The Personnel and Guidance Journal, 61(10), 620-622. https://doi.org/10.1111/j.21644918.1983.tb00010.x

Ranero, J. J. (1999, April 27). The Factors that Influence the College Choice of Hispanic College Students (thesis). Virginia Tech. Retrieved from https://vtechworks.lib.vt.edu/handle/10919/32348

Rowan-Kenyon, H. T., Bell, A. D., \& Perna, L. W. (2008). Contextual Influences on Parental Involvement in College Going: Variations by Socioeconomic Class. The Journal of Higher Education, 79(5), 564-586. https://doi.org/10.1353/jhe.0.0020 
Sanoff, A. P., \& Powell, D. S. (2003). Restricted Access: The Doors to Higher Education Remain Closed to Many Deserving Students. Lumina Foundation Focus, Summer 2003. Retrieved from http://eric.ed.gov/?id=ED481885

SB724 (Scott), As Amended on April 5, 2005 Scheduled for Hearing in the Assembly Higher Education Committee on July 5, 2005 Position (Oppose). (2005, June 22). Retrieved from http://www.ucop.edu/acadinit/mastplan/edd/SB\%20724_062205.pdf

Schlossberg, N. K. (1981). A Model for Analyzing Human Adaptation to Transition. The Counseling Psychologist, 9(2), 2-18. https://doi.org/10.1177/001100008100900202

Schlossberg, N. K. (1984). Counseling adults in transition: linking practice with theory. New York: Springer Pub. Co.

Schlossberg, N. K. (1989). Marginality and mattering: Key issues in building community. New Directions for Student Services, 1989(48), 5-15. https://doi.org/10.1002/ss.37119894803

Schmidt, P. (2003). Academe's Hispanic future (Vol. 50.14, pp. A8-A13). Chronicle of Higher Education.

Seay, S. E., Lifton, D., Wuensch, K. L., Bradshaw, L. K., \& McDowelle, J. O. (2008). First-Generation Graduate Students and Attrition Risks. The Journal of Continuing Higher Education., 56(3), 11. 
Sellers, N., Satcher, J., \& Comas, R. (1999). Children's Occupational Aspirations: Comparisons by Gender, Gender Role Identity, and Socioeconomic Status. Professional School Counseling, 2(4), 314.

Senate Bill No. 724 Chapter 269. (2005, September 22). California Govenor.

Snyder, T. D., \& Dillow, S. A. (2015). Digest of Education Statistics, 2013. Retrieved from http://nces.ed.gov/programs/digest/d13/

Stanton-Salazar, R. (2011). A Social Capital Framework for the Study of Institutional Agents and Their Role in the Empowerment of Low-Status Students and Youth. Youth \& Society, 43(3), 1066-1109.

Stebleton, M. J., \& Soria, K. M. (2012). Breaking down Barriers: Academic Obstacles of First-Generation Students at Research Universities. Learning Assistance Review, 17(2), 7-20.

Striplin, J. J. (1999). Facilitating Transfer for First-Generation Community College Students. ERIC Digest. Retrieved from http://eric.ed.gov/?q=ed430627\&id=ED430627

Sweitzer, V. B. (2009). Towards a Theory of Doctoral Student Professional Identity Development: A Developmental Networks Approach. Journal of Higher Education, 80(1), 1-33.

Tate, K. A., Williams III, C., \& Harden, D. (2013). Finding Purpose in Pain: Using Logotherapy as a Method for Addressing Survivor Guilt in First Generation College Students. Journal of College Counseling, 16(1), 79-92. 
Terenzini, P. T., Springer, L., Yaeger, P. M., Pascarella, E. T., \& Nora, A. (1996). FirstGeneration College Students: Characteristics, Experiences, and Cognitive Development. RESEARCH IN HIGHER EDUCATION -NEW YORK-, 37(1), 122.

Thayer, P. (2000). Retention of Students from First Generation and Low Income Backgrounds. Opportunity Outlook, 2(8). Retrieved from http://files.eric.ed.gov/fulltext/ED446633.pdf

Thelin, J. R. (2004). J. R. Thelin's. The Johns Hopkins University Press.

The NCES Fast Facts Tool provides quick answers to many education questions (National Center for Education Statistics). (n.d.). Retrieved December 17, 2016, from https://nces.ed.gov/fastfacts/display.asp?id=72

Tierney, W. G., \& Hagedorn, L. S. (2002). Increasing Access to College: Extending Possibilities for All Students. SUNY Press.

Tinto, V. (1975). Dropout From Higher Education: A Theoretical Synthesis of Recent Research. Review of Educational Research, 45(1), 89-125.

Tinto, V. (1988). Stages of Student Departure: Reflections on the Longitudinal Character of Student Leaving. Journal of Higher Education, 59(4), 438-55.

Tinto, V. (2006). RESEARCH AND PRACTICE OF STUDENT RETENTION: WHAT NEXT? Journal of College Student Retention: Research, Theory and Practice, 8(1), 1-19. https://doi.org/10.2190/4YNU-4TMB-22DJ-AN4W 
Vargas, J. (2004). College Knowledge: Addressing information barriers to college. Boston MA: The Education Resource Institute.

Warburton, E. C., Bugarin, R., \& Nunez, A. M. (2001). Bridging the Gap: Academic Preparation and Postsecondary Success of First-Generation Students. Statistical Analysis Report. (Statistical Analysis Report). Retrieved from http://eric.ed.gov/?id=ED456168

Wilson, W. J. (2010). More than just race: being black and poor in the inner city. New York; London: W. W. Norton.

Woosley, S., \& Shepler, D. (2011, December 1). Understanding The Early Integration Experiences of First - Generation College Students. Retrieved from http://search.proquest.com/openview/a03e02183c8bc1b652b742ad86a31907/1?pq -origsite $=$ gscholar

Yosso, T. J. (2005). Whose culture has capital? A critical race theory discussion of community wealth. Race Ethnicity and Education, 8(1), 69-91. 


\section{APPENDIX I}

\section{San Francisco State University}

\section{Informed Consent to Participate in Research}

Uncharted Path: Understanding The Experiences of First Generation Students on Their Journey Toward the Education Doctorate in The California State University System

\section{A. PURPOSE AND BACKGROUND}

The purpose of this research is to gain a better understanding of the experiences of students in the Education Doctoral Program in the California State University System. Specifically, this research seeks to better understand how California State University supports underserved populations who reach the doctorate.

The researcher, Clyde Henry Lewis, Jr. is a graduate student at San Francisco State University conducting research for his dissertation in the Educational Leadership department. You are being asked to participate in this study because you were both accepted and enrolled in an education doctorate in the California State University system.

\section{B. $\quad$ PROCEDURES}

If you agree to participate in this research, the following will occur:

- you will be asked to complete a survey that will take approximately 5 minutes to complete. This survey will be sent via email

- you may be asked to participate in two interviews, the first interview will take approximately ninety (90) minutes and the follow up interview will take approximately 45 minutes.

- both interviews will focus on your experience as you progressed through education toward the education doctorate.

- the interview will be audio recorded to ensure accuracy in reporting your statements.

- the interview will take place via SKYPE (or another comparable video conference tool) at a time convenient for you. 
- the researcher may contact you later to clarify your interview answers for approximately fifteen minutes within one month of the interview.

- total time commitment will be 150 minutes

\section{RISKS}

Risks include potential loss of privacy and emotional discomfort. In order to minimize these risk

for this research no names or identities will be used in any published reports of the research. Only the researcher will have access to the research data. You, the participant are asked to answer only those questions you choose to answer, and you can stop participation in the research at any time.

\section{CONFIDENTIALITY}

The research data will be kept in a secure office located in Burk Hall 521 and only the researcher and advisor will have access to the data. All research data will be stored in an encrypted document on a password protected computer in Burk Hall 521 for a minimum of three (3) years. After the completion of data analysis, all identifiable information will be destroyed immediately after being coded and transcribed.

All video recording will be destroyed upon completion of transcription and analysis.

All electronic research data will be stored in a device with full encryption and password protection.

\section{E. DIRECT BENEFITS}

There will be no direct benefits to the participant.

\section{F. $\underline{\text { COSTS }}$}

There will be no cost to you for participating in this research.

\section{G. COMPENSATION}


By participating in the survey, you will have the option to be entered into a drawing to win one (1) of four (4) \$25 visa gift cards.

\section{H. ALTERNATIVES}

The alternative is not to participate in the research.

\section{I.. OUESTIONS}

You have spoken with Clyde Henry Lewis, Jr. about this study and have had your questions answered. If you have any further questions about the study, you may contact the researcher by email at chlewis@mail.sfsu.edu or you may contact the researcher's advisor, Professor Jamal Cooks at jamalc@sfsu.edu.

Questions about your rights as a study participant, or comments or complaints about the study, may also be addressed to the Human and Animal Protections at 415: 3381093 or protocol@sfsu.edu.

\section{J. CONSENT}

You have been given a copy of this consent form to keep.

PARTICIPATION IN THIS RESEARCH IS VOLUNTARY. You are free to decline to participate in this research, or to withdraw your participation at any point, without penalty. Your decision whether or not to participate in this research will have no influence on your present or future status at San Francisco State University.

Signature

Date:

Research Participant

Signature

Date:

Researcher 


\section{APPENDIX II}

\section{Email to Program Directors}

Dear Dr. Program Director,

I am following up on Dr. Robert Gabriner's request to distribute my survey to your current and alumni students. My research aims to examine the educational experiences of students in CSU Education Doctoral Programs. This survey is the initial stage of my mixed methods dissertation research and will focus primarily on gathering demographic information.

Survey responses will allow us to hone in on a representative sample of education doctoral students for interview. The interview data will enable me to examine the factors that have contributed to student success.

Having you send out the survey is important in two ways:

1. Receiving the email from the program director increases the likelihood of response

2. Having you send the email maintains student anonymity for those students who choose not to respond.

Your support in this effort is integral to understanding how the CSU has contributed to the diversification of Doctoral trained education professionals in the California.

Please direct students to the below link. Please also note that some users have experienced issue when using the Safari web browser.

https://sfsu.col.qualtrics.com/SE/?SID=SV bp7U3VuSOOz7Nd3

Thank you,

Clyde H. Lewis

San Francisco State University Doctoral Candidate 


\section{APPENDIX III}

Understanding the Experiences of Students on Their Journey Toward the Education Doctorate

Dear Prospective Research Participant,

My name is Clyde Lewis, a third-year doctoral student at San Francisco State University. I am conducting research on the educational experiences of Education Doctoral (Ed.D.) students in the California State University (CSU) System. Specifically, I am interested in learning about the characteristics, motivators and barriers of Ed.D. students on their path toward the doctorate.

You were selected to participate in this research because you were admitted to and enrolled in an Education Doctoral Program at one of the CSU campuses. The findings from this research will be used to inform my dissertation research, which aims to underscore the role that CSU Ed.D. programs play in diversifying the pool of Doctoral trained education professionals in California.

Should you choose to participate, the questionnaire below contains 21 -items and should take no more than 10 minutes to complete. You may be assured of complete confidentiality. Your email address will be stored only to track survey completion. Please answer only the questions you feel comfortable answering. By submitting your questionnaire, it is understood that you consent to the above conditions.

Participants must be at least 18 years of age.

Please direct all inquiries to Principal Investigator, Clyde Lewis chlewis@mail.sfsu.edu or his research advisor, Dr. Jamal Cooks jamalc@sfsu.edu. If you are interested in 
participating in a follow up interview about your experiences, please include your contact information at the end of this questionnaire.

Participants will also have the option of being entered into a drawing for a chance to receive one (1) of four (4) \$25 visa gift cards. Thank you in advance for your participation.

Sincerely,

Clyde H. Lewis Jr. 
Student Characteristics This section focuses on gathering demographic information.

1 What is your age?

2 Which of the following choices best identifies your ethnic group?

O Native American, Alaskan Native (1)

O African American (2)

O Chicano, Mexican American (3)

O Other Latino (4)

O Asian (5)

O Filipino (6)

O Hawaiian/ Pacific Islander (7)

O White, Non-Latino (8)

O Multiethnic (13)

O Unknown (10)

3 How would you identify your gender?

O Male (1)

O Female (2)

Trans-gender (5)

4 What is the highest level of education completed by the female parental figure in your household growing up (e.g., mother, grandmother, step-mother)?

O 8th Grade or below (1)

O High School (2)

O Bachelors Degree (3)

O Graduate Degree or Beyond (5)

No female parental figure (6) 
5 What is the highest level of education completed by the male parental figure in your household growing up (e.g., father, grandfather, step-father, uncle)?

8th Grade or Below (1)

O High School (2)

O Bachelors Degree (3)

O Graduate Degree or Beyond (4)

O No male parental figure (5)

\section{Education Journey}

This section focuses on gathering information about your education experiences.

6 Did you attend community college before attending a 4-year institution?

O Yes (1)

O No (2)

7 Were you involved in any college transition programs before starting college (e.g., Upward Bound, Summer Bridge)?

○ Yes (1)

O No (2)

8 Were you involved in any college transition programs during college (e.g., EOPS, TRiO)?

O Yes (1)

O No (2) 
9 Did you work at least 20 hours per week (excluding work study, internships) on a consistent basis as an undergraduate?
O Yes (1)
O No (2)

10 Did you receive financial support from your family while you were an undergraduate student?
O Yes (1)
O No (2)

11 Did you work off campus as an undergraduate student?

O Yes (1)

O No (2)

12 Did you work at least 20 hours per week (excluding work study, internships, etc.) on a consistent basis as a Master's student?

O Yes (1)

O No (2)

13 Did you receive financial support from your family while you were a graduate student?
O Yes (1)
O No (2)

\section{Motivators}

This section focuses on your reasons for wanting to pursue an Education Doctorate. 
14 Are you currently working in an education related field?

○ Yes (1)

O No (2)

15 Did you decide to pursue an education doctorate for career advancement (e.g., from Principal to Superintendent)?

O Yes (1)

O No (2)

Institutional Supports

This section focuses on the institutional resources that you used during your educational journey.

16 Did you live on campus when you were an undergraduate student?

O Yes (1)

O No (2)

17 Did you receive financial aid during your undergraduate studies?

O Yes (1)

O No (2)

18 Did you receive financial aid during your graduate studies?

O Yes (1)

O No (2) 
Education Barriers

This section focuses on potential barriers you faced on the path toward the education doctorate.

19 Did you stop-out from school as an undergraduate student? Stop-out refers taking a semester or more off from school.

O Yes (1)

O No (2)

Request for Interview This section requests your participation and is entirely voluntary.

20 Are interested in participating in a follow-up interview about your experience as a doctoral student?

$\square$ Yes (1)

No (2)

Display This Question:

If Are interested in participating in a follow-up interview about your experience as a doctoral student? $<0: p><\mid 0: p>$ \&nbsp; $<0: p><\mid 0: p>\quad$ \&nbsp; Yes Is Selected

Please provide your name, phone number and email address in the text box below.

21 Are you interested in being entered into a drawing to win one (1) of four (4) \$25 gift cards?

O Yes (1)

O No (2) 


\section{Display This Question:}

If Are you interested in being entered into a drawing to win one (1) of four (4) $\$ 25$ gift cards?\&nbsp; Yes Is Selected

Please provide your name, phone number and email address in the text box below. 


\section{APPENDIX IV \\ Email to Request Interview Participation}

Hello,

I hope this email finds you well. My name is Clyde Lewis, and I am a Doctoral student at San Francisco State studying Educational Leadership. For my Dissertation, I am studying the educational journey of first generation students who have reached the Doctorate in the California State University System. As you have agreed to participate in a follow up interview, I would like to request your participation in this research study. You will be asked to take part in a single, 1 hour interview. My goal is to complete all interviews by September 10, 2016.

As participants are located throughout California and to maintain consistency between respondents, interviews will be conducted via Skype. Interviews will be both audio and video recorded. Your decision whether to participate is entirely voluntary and any information that could be used to potentially identify your person will be disguised.

If you are available and interested, please include the following information in your response:

- A few days and times where you are available

- Skype Handle that you would like to use

If you would like additional information and/or would like to participate, please contact me by email atchlewis@sfsu.edu or by phone at (510)755-9836 so that we can schedule a time to meet.

Thank you, Clyde Lewis 